\title{
Surgical Management of the Scimitar Syndrome
}

\author{
Ujjwal Chowdhury $^{1}$, Robert Anderson ${ }^{2}$, Lakshmi Sankhyan ${ }^{1}$, Niwin George ${ }^{3}$, Niraj \\ Pandey $^{1}$, Abhinavsingh Chauhan ${ }^{1}$, Yatin arora ${ }^{3}$, and Shikha Goja ${ }^{1}$ \\ ${ }^{1}$ All India Institute of Medical Sciences \\ ${ }^{2} 1$ Institute of Genetic Medicine, Newcastle University, Newcastle-upon-Tyne, United \\ Kingdom Birmingham Children's Hospital, Birmingham, United Kingdom \\ ${ }^{3}$ Affiliation not available
}

July 18, 2021

\begin{abstract}
The morphology variations of the so-called scimitar vein are many and varied. We present a synthesis of 92 published investigations of the overall scimitar syndrome. We reviewed the clinical presentations, diagnostic modalities, surgical approaches, and outcomes. Diagnostic information was provided by clinical presentations, radiographic findings, transthoracic and transesophageal echocardiography, computed-tomographic angiography, magnetic resonance imaging, angiocardiography, and ventilation/perfusion scans. These investigations served to elucidate the origin, course, and termination of the scimitar vein, the intracardiac anatomy, the presence of associated defects, and the patterns of any accompanying pulmonary lesions. In short, they defined the disease prior to surgical intervention. Of the patients described, up to four-fifths presented during infancy, with cardiac failure, increased pulmonary flow, and pulmonary hypertension. Associated cardiac and extracardiac defects, particularly hypoplasia of the right lung, are present in up to three-quarters of cases. Overall operative mortality has been cited between $4.8 \%$ and $5.9 \%$. Mortality was highest in patients with preoperative pulmonary hypertension, and those undergoing surgery in infancy. Despite timely surgical intervention, post-repair obstruction of the scimitar vein, intra-atrial baffle obstruction, or stenosis of the inferior caval vein were reported in up to two-thirds of cases. The venous obstruction could not be related to any particular surgical technique. On long term follow-up, one sixth of patients reported persistent dyspnoea and recurrent respiratory infections. Any infants presenting with heart failure, right-sided heart, and hypoplastic right lung should be evaluated to exclude the syndrome. An increased appreciation of variables will contribute to improved surgical management.
\end{abstract}

\section{Surgical Management of the}

Scimitar Syndrome

Running title: Scimitar syndrome

Ujjwal Kumar Chowdhury, MCh, Diplomate NB ${ }^{1}$

Robert H. Anderson, BSc, MD, PhD (Hon), FRCPath, FRCS Ed (Hon) ${ }^{2}$

Lakshmi Kumari Sankhyan, $\mathrm{MCh}^{3}$

Niwin George, $\mathrm{MCh}^{1}$

Niraj Nirmal Pandey, DM ${ }^{1}$

Abhinavsingh Chauhan, $\mathrm{MCh}^{1}$

Yatin Arora, $\mathrm{MCh}^{1}$

Shikha Goja, MS ${ }^{1}$ 
Cardiothoracic Centre, All India Institute of Medical Sciences ${ }^{1}$, New Delhi and Bilaspur, Himachal Pradesh ${ }^{3}$

Institute of Biomedical Sciences ${ }^{2}$, Newcastle University, Newcastle-upon-Tyne, United Kingdom

Cardiothoracic Centre

All India Institute of Medical Sciences, New Delhi ${ }^{1}$ and Bilaspur ${ }^{2}$

Correspondence:

\section{Dr. Ujjwal Kumar Chowdhury, M.Ch., Diplomate NB}

Professor

Department of Cardiothoracic and Vascular Surgery

AIIMS, New Delhi-110029, INDIA

Tel.: 91-11-26594835

Fax: 91-11-26588641

Email: ujjwalchow@rediffmail.com

ujjwalchowdhury@gmail.com

Orcid ID: http: //orcid.org/0000-0002-1672-1502

Word Count: Abstract (246), Text (4947), References (512), Figure legends (560)

Statement of human rights/ethical approval: The authors assert that all procedures contributing to this study comply with the ethical standards of the relevant national guidelines on human experimentation and with the Helsinki declaration of 1975, as revised in 2008.

Conflict of interest : No potential conflicts exist

Source of funding : No funding was provided

Availability of Data: Data available in article supplementary material.

\section{Abstract}

The morphology variations of the so-called scimitar vein are many and varied. We present a synthesis of 92 published investigations of the overall scimitar syndrome. We reviewed the clinical presentations, diagnostic modalities, surgical approaches, and outcomes. Diagnostic information was provided by clinical presentations, radiographic findings, transthoracic and transesophageal echocardiography, computed-tomographic angiography, magnetic resonance imaging, angiocardiography, and ventilation/perfusion scans. These investigations served to elucidate the origin, course, and termination of the scimitar vein, the intracardiac anatomy, the presence of associated defects, and the patterns of any accompanying pulmonary lesions. In short, they defined the disease prior to surgical intervention.

Of the patients described, up to four-fifths presented during infancy, with cardiac failure, increased pulmonary flow, and pulmonary hypertension. Associated cardiac and extracardiac defects, particularly hypoplasia of the right lung, are present in up to three-quarters of cases. Overall operative mortality has been cited between $4.8 \%$ and $5.9 \%$.

Mortality was highest in patients with preoperative pulmonary hypertension, and those undergoing surgery in infancy. Despite timely surgical intervention, post-repair obstruction of the scimitar vein, intra-atrial baffle obstruction, or stenosis of the inferior caval vein were reported in up to two-thirds of cases. The venous obstruction could not be related to any particular surgical technique. On long term follow-up, one sixth of patients reported persistent dyspnoea and recurrent respiratory infections. Any infants presenting 
with heart failure, right-sided heart, and hypoplastic right lung should be evaluated to exclude the syndrome. An increased appreciation of variables will contribute to improved surgical management.

Key words: Scimitar syndrome, Anomalous pulmonary venous connection, Pulmonary sequestration, Horse-shoe lung, Congestive heart failure, Hypogenetic lung syndrome, Congenital pulmonary venolobar syndrome, Vena cava bronchovascular syndrome, Mirror-image lung syndrome

\section{Introduction}

The Scimitar syndrome is a rare congenital malformation characterized by totally or partially anomalous pulmonary venous connection of the right lung to the inferior caval vein or right atrium, variable hypoplasia of the right lung, a right-sided heart with normally related cardiac chambers, and variable systemic arterial supply to the right lung. ${ }^{1-7}$ The phenotypic feature is the anomalous pulmonary venous connection, which produces the characteristic shadow on the chest radiograph that resembles the Turkish scimitar. ${ }^{8-10}$

The incidence of the syndrome is relatively low, representing no more than around one-twentieth of all cases of partially anomalous pulmonary venous connection. ${ }^{7}$ The estimated prevalence is from 1 to 3 per 100,000 births. It is associated with other congenital cardiac malformations in up to three-quarters of cases. ${ }^{11-13}$ The first description of the findings now known as the Scimitar syndrome was made at autopsy by Cooper and Chasinat in 1836. The findings were then recognised in an asymptomatic live patient in 1949 by Dotter. ${ }^{1,2,14}$ It was Halsz and associates, however, who first used the term "scimitar", in 1956, when describing the appearance of the abnormal vein. Neil and associates, in 1960, then named the syndrome after the Turkish sword. ${ }^{15,16} \mathrm{~A}$ right lower lobectomy in a patient with the findings now recognised as representing the syndrome had been performed in 1950 by Drake and Lynch, ${ }^{17}$ while Kirklin, Ellis and Wood had corrected the overall findings in $1956 .{ }^{18}$

Due to the small number of reported cases, and limited description of clinical details, it is difficult to draw conclusions regarding the indications and outcomes for surgical as opposed to non-surgical management. For the purposes of our review, however, we have evaluated all clinical and necropsy studies describing individuals recognised as having the syndrome and undergoing either conservative or surgical management (Table E1).

We assessed the locations of the anomalous pulmonary venous connection to supradiaphragmatic or infradiaphragmatic inferior caval vein, the course of scimitar vein in relation to the hilum of right lung, the degree of hypoplasia of the right pulmonary veins, the source of anomalous arterial supply to right lung, any associated congenital cardiac lesions, the degree of hypoplasia of either the right or left lung, and the size and pattern of drainage of the left-sided pulmonary veins. This has permitted us to collate the anatomical details, the diagnostic challenges, the associated cardiac anomalies, and the techniques and outcomes of management, including reinterventions.

\section{Methods}

We searched the literature to identify the described instances of scimitar syndrome, with detailed anatomical description, associated cardiac and non-cardiac anomalies, any association with so-called heterotaxy syndrome, the surgical and non-surgical therapeutic options, and their outcomes. The search engines employed were PubMed, Google Scholar, Cochrane Database for Systematic Reviews, Cochrane Central Register of Controlled Trials, Ovid Medline, ACP Journal Club, Ovid EMBASE, and Database of Abstracts of Review of Effectiveness in all languages.

Analysis was based initially on the individualized review of 91 investigations. ${ }^{1-4,6-20, E 1-E 72}$ These were then incorporated from the results of the retrospective study emanating from the multi-centric European Registry, which itself had collated the findings from 485 patients from 51 institutions, being carried out under the auspices of the Association for European Pediatric Cardiology and the European Congenital Heart Surgeons Association. ${ }^{5, \mathrm{E} 72}$

Due to the limited size of the reported series, and the heterogeneity of the clinical state at the time of surgical intervention, along with the difficulties in selection of appropriate cardiac quantifiable end-points, we were 
unable to perform a meta-analysis. Our analysis therefore, is based on review of case reports and small case series, along with incorporation of data from the more extensive series reported from the Joint Multicentric Registry. ${ }^{1-20, E 1-E 72}$

\section{Morphogenesis}

The errors accounting for this developmental constellation are not well understood. As the lung bud development progresses, its primary blood supply changes from a plexus derived from the descending aorta to the portion of the ultimate pharyngeal arches that give rise to the pulmonary arteries, a transition that is complete after the $7^{\text {th }}$ week of gestation. With normal development, pulmonary venous connection to the left atrium is completed by the $11^{\text {th }}$ week of gestation. In 1999, Huddleston and Mendeloff suggested an insult could have occurred which would culminate in failure of this "hand-over", resulting in the persistence of systemic arterial supply to the right lung from the abdominal aorta, and underdevelopment of the right pulmonary artery and right lung. ${ }^{\mathrm{E} 2}$ The syndrome represents a more primitive derangement than the usual forms of partially or totally pulmonary venous connections. It has been suggested that it may be related to disturbed laterality signalling. ${ }^{\text {E50 }}$

\section{Results}

\section{Demographics}

The age of reported patients ranges from 1 day to 72 years. In the Joint Multicentric Registry, median age at diagnosis was 0.48 years, with an interquartile range from 0.1 to 5.2 years. Among 485 reported cases, with a ratio of 1.4 females to 1 male, almost three-fifths were neonates or infants, around onequarter were aged between 1-10 years, and one-fifth were older than 10 years. ${ }^{3-5}$ There was no identifiable regional or ethnic predominance, with isolated reports of bronchial isomerism and familial occurrence were seen. ${ }^{11,12,16, \mathrm{E} 22, \mathrm{E} 25, \mathrm{E} 26}$

The clinical presentation varies from being asymptomatic to significant heart failure. The age at presentation can accordingly differ significantly from infancy to adulthood. ${ }^{\text {E27 }}$ Some have sub-classified the syndrome into the groups of isolated presentation in infancy, presentation in infancy with congenital heart diseases, and isolated presentation during adulthood (Table E1). ${ }^{3,11,12}$ In this regard, half of adults or adolescents reported in the multicentric European study present as isolated cases with a slight degree of right pulmonary hypoplasia, one-third were asymptomatic, while half reported a history of recurrent infections of the respiratory tract. $^{3-5,9,11,12, \mathrm{E} 2, \mathrm{E} 20-\mathrm{E} 22}$

\section{Diagnosis}

The diagnosis is straightforward when the scimitar sign is recognised on the chest radiograph in association with hypoplasia of the right lung, a right sided mediastinal shift, a right-sided heart, or an opacified right hemithorax. ${ }^{20, \mathrm{E} 27, \mathrm{E} 49}$ On occasion, however, a meandering but normally connected pulmonary vein may be confused for a scimitar vein. ${ }^{\mathrm{E} 27, \mathrm{E} 49, \mathrm{E} 50}$ The scimitar sign, nonetheless, may be absent due to hypoplasia of the right lung and a right-sided heart, or a prominent thymus, these changes obfuscating the venous shadow. ${ }^{\mathrm{E} 27, \mathrm{E} 49, \mathrm{E} 51}$

Accurate anatomical information prior to surgery is desirable, as the surgical strategy depends on the configuration and site of drainage of the scimitar vein. The restricted imaging windows limit the usage of transthoracic echocardiography in assessing the exact site of drainage in the prenatal period, and in adults. ${ }^{\mathrm{E} 29, \mathrm{E} 51, \mathrm{E} 52}$ Transesophageal echocardiography is useful in confirming the diagnosis preoperatively, and in postoperative assessment of the patency of the scimitar vein. ${ }^{\text {E18,E32,E49,E52-E55,E57 }}$

On duplex sonography, the normal pulmonary venous flow is biphasic or triphasic, with one or two peaks in systole, one peak in diastole, and reverse flow at atrial contraction. The flow in the scimitar vein, however, is monophasic, extending throughout the cardiac cycle with no reverse flow with atrial contraction. This

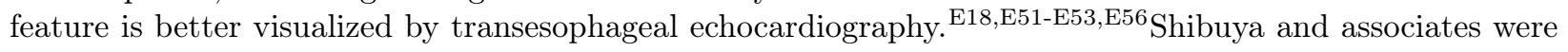


able to characterize the anomalous venous connection in nine-tenth of their cases when using color flow mapping, as opposed to only one-sixth without. ${ }^{\text {E52 }}$

Contrast computed tomography, and/or 3-D magnetic resonance angiography, now provide comprehensive assessment of the intracardiac anatomy, the diameter, trajectory, and site of drainage of the scimitar vein, and its relationship to the hilum of right lung (Figures $1 \& 2$ ). The technique may now safely be used to

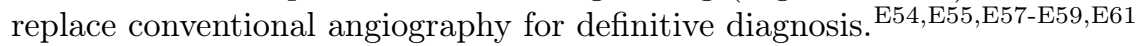

Angiocardiography may still be indicated in doubtful cases, for coil embolization of the aortopulmonary collateral arteries, or for therapeutic intervention should the scimitar vein be stenosed. ${ }^{3-5,11,12, E 20, \text { E21 }}$ Ventilation/perfusion scans are recommended as a routine by some investigators for pre- and postoperative evaluation. ${ }^{\text {E17 }}$ Routine bronchoscopy and bronchography are also recommended by others. ${ }^{\text {E17,E28 }}$

\section{Surgical Anatomy}

The Scimitar vein typically drains the entire right lung, but may occasionally drain only the lower or middle lobe. ${ }^{\mathrm{E} 28}$ It can course either anterior or posterior to the hilum of the right lung. It is not always be wide and curved like a scimitar, but rather may be straight, thin or multiple. It connects usually to the inferior caval vein, but cases are described with connection to the superior caval vein or the right atrium. ${ }^{19, \mathrm{E} 2 \text {, E22, E22 }}$ When connecting to the inferior caval vein, the site of connection is usually subdiaphragmatic, but can be supradiaphragmatic or to the inferior cavoatrial junction. ${ }^{\text {E30 }}$ The vein was reported as stenotic in one-fifth of patients, this being a harbinger for a poor prognosis.(Figure 2) E50 $^{\mathrm{E} 0}$

Left-sided scimitar veins have also been described. ${ }^{6-10}$ For example, in 2005, Juraszek and associates described an isolated case in whom all the left pulmonary veins joined together in a confluence below the left atrium, and then drained subdiaphragmatically into the right-sided inferior caval vein. ${ }^{8}$ Such left-sided connections are less frequently obstructive, but may cause refractory pulmonary hypertension. ${ }^{9}$ Pulmonary arterial hypertension may occur in one-third of all cases, being observed mainly in neonates and infants with congenital heart diseases, but only rarely in isolated cases. ${ }^{3-5,11,12}$

Associated cardiac and extracardiac anomalies were reported in one-third to three-quarters of patients. ${ }^{\text {E31 }}$ Cardiac anomalies included atrial and ventricular septal defects, functionally univentricular hearts, double outlet right ventricle, tetralogy, tricuspid atresia, anomalous origin of the left coronary artery from the pulmonary trunk, double chambered right atrium, left-sided obstructive lesions, and stenosis of the inferior caval and pulmonary veins. ${ }^{3-5, \mathrm{E} 32, \mathrm{E} 33, \mathrm{E} 40-\mathrm{E} 72}$

Associated extracardiac anomalies included patency of the arterial duct, coarctation of aorta, arch obstruction, abnormal lobation of the right lung, hypoplasia of the right lung, pulmonary sequestration, the scimitar vein draining the entirety of both lungs, interruption of the inferior caval vein, obstruction of the scimitar vein at its caval connection, pulmonary arterial hypoplasia, and aortopulmonary collateral arteries. ${ }^{\text {E34-E36 }}$ Hemivertebras, proximal rib fusion, subnumerary ribs, and micromelia of the arms have all been reported at necropsy. ${ }^{54-56}$ Hypoplasia of the right lung to varying degree has been reported in cardiac position. ${ }^{3-5, E 72}$

An anomalous arterial supply from the descending thoracic or abdominal aorta typically perfuses the lower or middle lobes, but may infrequently perfuse the whole right lung. ${ }^{\text {E37-E39 }}$ Hyperperfusion of the left lung was reported in three-quarters of cases on pulmonary scintigraphy. ${ }^{\text {E28 }}$ Tracheobronchial abnormalities in the form of sequestration, diverticulums, stenosis or atretic bands have been reported. There are no reported cases with a normal bronchogram. ${ }^{\text {E28 }}$ Najm and associates reported just over two-fifths incidence of pulmonary sequestration in their series of 32 patients. ${ }^{19}$ Bronchial sequestration, however, is rarely present. ${ }^{7 \text { E17 }}$ There are, nonetheless, 14 patients reported with horseshoe lungs, the two lungs being fused at the postero-inferior segments posterior to the heart and in front of esophagus. ${ }^{11,12,19, \mathrm{E} 41-\mathrm{E} 43}$ The right pulmonary artery and right bronchus usually cross the midline to supply part of the left lung.

\section{Surgical Approaches and Management}

Management, including indications, timing, and type of intervention remain nebulous. ${ }^{3-5,11,12,19-20, \mathrm{E} 2}$ During 
infancy, unless pulmonary hypertension develops, medical treatment is indicated to offset heart failure, and allow growth before surgical repair. Pulmonary hypertension, however, must be addressed before surgery, either by medical intervention or by reducing pulmonary blood flow by coil embolization of aortopulmonary collateral arteries. ${ }^{3-5,11,12, \mathrm{E} 72}$ Some authors recommend early surgical intervention if cardiopulmonary bypass and cardiac arrest are not used in the repair procedure. ${ }^{\mathrm{E7}}$ In general, surgical correction is recommended in all symptomatic patients, and in asymptomatic patients with pulmonary-to-systemic flow ratios greater than 1.5:1, or pulmonary-to-systemic flow ratio lesser than $1.5: 1$ in the settings of clinically treated pulmonary hypertension, stenosis of the scimitar vein, or concomitant cardiac lesions. ${ }^{19, \mathrm{E} 1, \mathrm{E} 21}$

The indications for surgery in adults is still debated, since many adults with the syndrome lead a normal life without surgical treatment. The general consensus, nonetheless, is that surgery is indicated in symptomatic patients, or when the pulmonary-to-systemic flow ratio is greater than 1.5 in asymptomatic patients. Diuretics, sodium potassium/ATPase inhibitors, $\beta$-agonist, ipratropium bromide, antibiotics and cortisones are used on an individualized basis. ${ }^{3-5,11,12, \mathrm{E} 72}$

Principles of surgical treatment are creation of an unrestricted pathway for the scimitar vein through an existing or newly created interatrial communication, without causing tension, torsion, kinking, flattening, or stenosis of the scimitar vein, Concomitant anomalies are also repaired. In symptomatic patients when the vein cannot be rerouted to the left atrium, lobectomy, pneumonectomy, or heart lung transplantation are considered according to the situation. Multiple individual techniques are reported for surgical correction (Table E2).

Division and reimplantation of the scimitar vein into the right atrium without cardiopulmonary bypass

In 1956, Kirklin, Ellis and Wood reported the first total correction of the lesions making up the syndrome by translocating the scimitar vein to the right atrium without utilizing bypass. By means of a Bailey atrioseptopexy, the flow was then directed to the left atrium through the oval foramen. ${ }^{18, \mathrm{E} 3}$

Division and translocation of the scimitar vein into the right atrium

Shumacker and Judd described this technique in 1964. They divided the Scimitar vein along with a cuff of the inferior caval vein, transplanting it to the right atrium adjacent to the oval fossa such that flow could be directed to the left atrium. The cuff of caval venous wall provides more robust tissue for anastomosis. The inferior caval vein itself was patched to avoid stenosis. The technique has since been used with satisfactory results (Figure 3). ${ }^{13,19, \mathrm{E} 5, \mathrm{E} 6}$

Direct implantation of the scimitar vein to the left atrium via median sternotomy

This involves mobilisation of the vein, bringing it through a large pericardial opening posterior to phrenic nerve, and anastomosing it to the left atrium. ${ }^{\text {E66 }}$

Division and translocation of the scimitar vein into the left atrium via right thoracotomy without cardiopulmonary bypass

This technique was described for both infants and adults without concomitant cardiac anomalies. Through a right anterolateral thoracotomy, scimitar vein was harvested with a venous cuff and sutured to the left atrium (Figure 4). ${ }^{\mathrm{E} 2, \mathrm{E} 6-\mathrm{E} 8}$

Division and translocation of the scimitar vein into the left atrium using Dacron graft interposition via right thoracotomy.

This technique was described in 1968, interposing a $20 \mathrm{~mm}$ Dacron graft. ${ }^{7,19}$

Division and translocation of the scimitar vein into the left atrium using polytetrafluoroethylene graft interposition

Lam and associates anastomosed a polytetrafluoroethylene graft between the scimitar vein and the left atrium (Figure 5). ${ }^{\text {E9 }}$ 
Division and translocation of the scimitar vein into the left atrium via pericardial tunnel

This innovative method was described in 2014 by Lugones and Garcia. The scimitar vein was transected at the level of diaphragm and both ends were over sewn. A large incision was made in right lateral wall of the pericardium. Then under cardioplegic arrest, a pericardial anastomosis was created to a large vertical left atriotomy (Figures $6 \mathrm{~A}-6 \mathrm{C}) .{ }^{\text {E10 }}$

Partitioning of the inferior caval vein and rechanneling of the scimitar vein into the left atrium

In 2003, Calhoun and Mee used a pericardial patch to partition the inferior caval vein, ${ }^{\text {E11 }}$ creating a posterior compartment receiving the scimitar venous blood which was sutured to the left atrium. The anterior compartment receiving the systemic venous blood remained connected to the right atrium (Figures 7A, 7B).

Intra-atrial baffle

Either polytetrafluroethylene $\mathrm{E}^{\mathrm{E} 12}$ or the free wall of the right atrium ${ }^{\mathrm{E} 13}$ have been used to baffle the orifice of scimitar vein through an existing or newly-created interatrial communication to the left atrium (Figures $8 \mathrm{~A}, 8 \mathrm{~B})$.

Division and translocation of scimitar vein into the left atrium with venous flap.

This technique involves harvesting the Scimitar vein together with a venoatrial flap and anastomosing it directly to the left atrium (Figure 9). ${ }^{\text {E65 }}$

Division and translocation of the scimitar vein using a ringed polytetrafluoroethylene extracardiac conduit

This technique involves creation of a pericardial window, with a ringed polytetrafluroethylene interposition graft then sewn end-to-end between the divided scimitar vein and the left atrium (Figure 10). E70

Atrial septectomy, and intra-atrial baffling

This technique, employing a polytetrafluroethylene patch was used in a patient with an intact atrial septum. ${ }^{\text {E14 }}$

Scimitar vein cut back technique

The technique of cutting up into the right atrium along the venoatrial junction resulted in taking away the angle from the anastomosis with the left atrium, thus decreasing the risk of stenosis at that site. ${ }^{19,20}$

Pericardial tunnel technique

This technique was used for the vertical scimitar vein, defined as an angle of insertion to the inferior caval vein of less than $45^{\circ} .{ }^{\text {E69 }}$ Under cardioplegic arrest, flow was directed to the left atrium inside a pericardial tunnel. ${ }^{\mathrm{E} 69}$

Repair by a novel multipatch technique

This novel operation enlarges the left atrium, and avoids circuitous pathways or tension on scimitar vein. The operation included resection of the atrial septum, making a V-shaped incision made at the venoatrial junction or into the scimitar vein, and anastomosing it to the left atrium. An autologous pericardial patch was used to separate the atriums, with an additional patch needed to augment the inferior caval vein. ${ }^{\text {E68 }}$

In situ pericardial roll repair for distant anomalous pulmonary venous return

This innovative technique, using dual pericardial rolls, is suitable for multiple anatomic configurations, and can be used for both infants and adults. ${ }^{\text {E64 }}$

Modified in situ pericardial rerouting and repositioning of atrial septum 
This approach is a modification of the so-called "sutureless" repair. The atrial septum was repositioned to create a wide opening in the lateral aspect of the left atrium, ensuring an adequate pathway. ${ }^{\text {E67 }}$

Pneumonectomy

Right pneumonectomy has been advised when the scimitar vein courses posterior to lung hilum to emerge from under the diaphragmatic surface of right lung. In this setting, it is difficult to mobilize the vein without

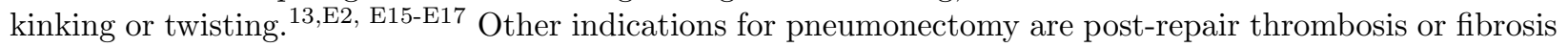
of the scimitar vein, or recurrent pulmonary venous stenosis. ${ }^{13, E 15-E 17}$

Lobectomy/resection of sequestered lung

Several authors have performed lobectomy for pulmonary sequestration with recurrent right-sided pneumonias. ${ }^{\text {E17,E18 }}$

Lung transplantation

Transplantation has been recommended for persistent postoperative pulmonary hypertension and recurrent pulmonary venous stenosis following surgery. ${ }^{9, \mathrm{E} 2}$

Orthotopic cardiac transplantation

A hybrid approach, or early cardiac transplantation, was recommended in the setting of a functionally univentricular heart and a severely hypoplastic pulmonary artery. ${ }^{13, E 19}$

Correction of associated cardiac anomalies

The associated congenital cardiac anomalies are treated on their own merits. ${ }^{1-5, E 72}$

Transcatheter therapy / surgical ligation of major aortopulmonary collateral arteries

Aortopulmonary collateral arteries are managed by either embolization using detachable mini balloon, mini coils, or tissue adhesive or by surgical transthoracic ligation. Balloon angioplasty and balloon expandable stainless steel Palmaz stent have been employed for stenotic anomalous pulmonary veins. ${ }^{3-5,9,13,19, E 2, E 20-E 24, E 60-E 72 ~}$

\section{Short- and Long-term Outcomes}

Early surgical outcomes are good for most individuals undergoing surgical correction. The overall risk of surgical repair is between $4.8 \%$ and $5.9 \% .^{5,11,13,19, \mathrm{E} 2, \mathrm{E} 5-\mathrm{E} 7, \mathrm{E} 10, \mathrm{E} 17, \mathrm{E} 22}$ The causes of death were presentation in infancy with concomitant congenital cardiac and extracardiac anomalies, severe pulmonary arterial hypertension, severe pulmonary hypoplasia with sequestration, respiratory failure and congestive cardiac failure. Patients undergoing resective procedures have a higher risk of death compared with those undergoing corrective surgery (36\% vs 3\%) (Table E3). ${ }^{5,11,13,19, \mathrm{E} 2, \mathrm{E} 5-\mathrm{E} 7, \mathrm{E} 10, \mathrm{E} 17, \mathrm{E} 22}$

Those patients with severe pulmonary hypoplasia, diffuse right-sided bronchiectasis, post baffle thrombosis / fibrosis of scimitar vein, recurrent pulmonary vein stenosis following dilatation / stenting and hypoplastic left heart syndrome continue to present a significant challenge. ${ }^{3-5, \mathrm{E} 6}$ Despite timely surgical intervention, operative mortality remains high in this subset of patients, and heart / heart-lung transplantation may be the only surgical option..$^{9,13, \mathrm{E} 2, \mathrm{E} 19}$

Regardless of the surgical techniques, venous or baffle obstruction are reported in between one-sixth and twothirds of cases. ${ }^{3-5,9, \mathrm{E} 6, \mathrm{E} 22, \mathrm{E} 23, \mathrm{E} 62}$ The specific technique did not seen to influence the rate of postoperative pulmonary venous obstruction. ${ }^{3-5,9,11-13,19, \mathrm{E} 6, \mathrm{E} 22, \mathrm{E} 23, \mathrm{E} 62-\mathrm{E} 64, \mathrm{E} 71, \mathrm{E} 72}$

In the joint European Registry, over nine-tenths of patients underwent corrective surgery, with the remaining patients having lung resection. In the series, almost half the patients were medically treated. At a mean follow-up of 7 years, late mortality was $4 \%$ in those surgically treated, and $6.5 \%$ in medically treated patients. Postoperatively, one-fifth of patients had scimitar venous stenosis, and $2 \%$ had total occlusion. This complication was related to neither the baffle nor reimplantation, and was more frequent in neonates 
and infants. Two-thirds of these patients underwent reintervention or reoperation at a median of 0.8 years after repair, with an interquartile range from 0.5 to 1.2 years. ${ }^{5}$ Persistent dyspnoea and recurrent respiratory infections were documented in $15 \%$ of surviving patients 4.5 years after surgery. ${ }^{3,5}$

Baffle repair or reimplantation techniques did not influence mortality or reoperation in the majority of the studies. ${ }^{3-5,11,12, \mathrm{E} 6, \mathrm{E} 7}$ The prognosis for infants with pulmonary hypertension is generally poor with or without surgery. The reported one-year survivals are $62.5 \%$ and $54 \%$ with surgical and medical treatment, respectively, suggesting the advantage of surgical intervention for symptomatic neonates. ${ }^{11,12, \mathrm{E} 5}$

The optimal management of symptomatic adults currently remains unclear. The proponents for surgical intervention, nonetheless, have demonstrated excellent long-term functional results. ${ }^{5,13, \mathrm{E} 6, \mathrm{E} 7, \mathrm{E} 22}$ Dupuis and associates, however, obtained a good result in only one-third of their surgically treated patients. Of 85 medically treated patients, 79 remained asymptomatic. ${ }^{11,12}$ Because of the frequent association of right lung malformations, many patients have poor lung perfusion despite having an unrestricted pathway. ${ }^{19}$

At a median follow-up of 7.2 years, in a cohort of 81 patients, Chemin and associates demonstrated persistent reduction of lung volume and air flow reflecting pulmonary hypoplasia. ${ }^{\text {E44 }}$

\section{Discussion}

Although patients with scimitar syndrome may be asymptomatic, presentation in infancy, occurring in threefifths, usually has shunt-induced congestive heart failure and pulmonary hypertension. ${ }^{3-5,9,11,12, \mathrm{E} 2, \mathrm{E} 20-\mathrm{E} 22, \mathrm{E} 44}$ The diagnosis should be suspected when an infant presents with tachypnoea, repeated chest infections, or other signs of heart failure in association with a right-sided heart and hypoplasia of the right lung. Adults, however, may remain asymptomatic. ${ }^{3-5,9,11,12, \mathrm{E} 2, \mathrm{E} 20-\mathrm{E} 22}$

Causative factors for severe symptoms and pulmonary hypertension are manifold. They include shunting from the scimitar vein or aortopulmonary collateral arteries. Associated congenital heart disease is another problem, as is a hypoplastic pulmonary vascular bed and a volume-overloaded left lung. Primary pulmonary hypertension of the newborn can also be a problem, along with pulmonary venous obstruction, or failure of involution of the pulmonary arterioles due to excessive pulmonary flow. ${ }^{11,12, \mathrm{e} 13, \mathrm{e} 45, \mathrm{e} 46}$ Pulmonary histopathology has demonstrated an increased muscularity of pulmonary arteries less than $300 \mu \mathrm{m}$ in diameter, suggesting failure of regression of mural thickness due to excessive pulmonary blood flow from birth. ${ }^{\mathrm{e}}{ }^{6, \mathrm{e} 47}$

The optimal surgical repair involves redirection or re-implantation of the scimitar vein to the left atrium without using synthetic vascular substitutes, without causing distortion, without attenuation of scimitar venous or pulmonary venous flow, and without kinking the contiguous vascular structures. That this ideal has yet to be achieved is evident from the numerous surgical techniques described, along with follow-up studies that report an undesirable incidence of post-operative venous or baffle obstruction. Reintervention, either surgical or by catheter, varies from $11 \%$ to $30 \% .{ }^{19, \mathrm{E} 22, \mathrm{E} 60, \mathrm{E} 62-\mathrm{E} 64, \mathrm{E} 71}$

Surgical strategies vary according to the configuration and drainage site of the anomalous pulmonary vein. Because of this, it is desirable to obtain accurate anatomical information in the preoperative period. The restricted imaging windows limit the usage of echocardiography in assessment of the exact course and location of the entry point of scimitar vein. Contrast-enhanced and multidetector computed tomography, and/or cardiac magnetic resonance imaging provide comprehensive assessment of the anomalous venous connection and flow characteristics. They are now safely used to replace angiography in the definitive diagnosis.

With the evolving knowledge of the complex variable anatomy, surgeons began to adopt individualized surgical techniques to suit the different pathological variants. Long-term outcomes of intracardiac baffling have been disappointing in infants due to pulmonary venous obstruction or inferior caval venous stenosis. ${ }^{3-5,19, \mathrm{E} 2, \mathrm{E} 3, \mathrm{E} 12, \mathrm{E} 21, \mathrm{E} 71, \mathrm{E} 72}$ The anatomical factors contributing to such obstruction include variable scimitar venous anatomy, the acute angle taken by the blood as it traverses the baffle to reach the left atrium, shrinkage and thrombosis of the baffle, and stenosis of the orifice of the scimitar vein. ${ }^{19, \mathrm{E} 2, \mathrm{E} 3}$

Although deep hypothermic circulatory arrest facilitates visualization of the infradiaphragmatic opening 
in small children, it is associated with an increased incidence of neurologic events. ${ }^{3-5, E 72}$ In an attempt to improve the results of baffling, several teams have proposed ingenious techniques. Puig Massana and Revuelta, for example, used the free wall of the right atrium. ${ }^{\text {E13 }}$ Calhoun and Mee compartmentalized the inferior caval vein into posterior and anterior compartments. ${ }^{\text {E11 }}$ Spray advocated cutting back the venoatrial junction to remove the angle from the anastomosis. ${ }^{19,20}$ Geggel and associates resected the atrial septum, employed a V-shaped incision at the scimitar venoatrial junction, and employed multiple patchs. ${ }^{\text {E68 }}$ Chan and colleagues described atrial septectomy and intra-atrial baffling. ${ }^{\text {E14 }}$ The long-term results of all these innovative procedures is unknown. ${ }^{\text {E14 }}$

Seeking to avoid the use of baffles, and stenosis of the scimitar vein, other ingenious techniques of division and translocation of scimitar vein with or without cardiopulmonary bypass have been proposed. They include division and translocation of scimitar vein and right atrium adjacent to a pre-existing interatrial communication, or creation of a defect if one is lacking. ${ }^{13,19, \mathrm{E} 5, \mathrm{E} 6}$ Janssen and colleagues divided the scimitar vein, bringing it through pericardial opening posterior to the phrenic nerve before anastomosing it to the left atrium. ${ }^{\text {E66 }}$ Brown and colleagues divided and translocated the scimitar vein into the left atrium via right thoracotomy without using bypass. ${ }^{\text {E7 }}$ This technique is also recommended in cases of posteriorly placed scimitar vein, for which some investigators have suggested pneumonectomy. ${ }^{\text {E7,E17 }}$ While it eliminated the long, complex, and angulated pathway associated with intracardiac baffling, the reported incidence of pulmonary venous obstruction has been high, likely due to pulmonary venous distortion or anastomotic stricture. ${ }^{3-5, \mathrm{e} 4, \mathrm{e} 12, \mathrm{e} 22, \mathrm{e} 71, \mathrm{e} 72}$ A recent series from Boston described an incidence of pulmonary venous obstruction of $46 \%$ with intracardiac baffling, and $68.8 \%$ with reimplantation procedures. ${ }^{\text {E22 }}$

The use of pericardial rolls as developed at the Cleveland Clinic avoids direct circumferential anastomosis of the delicate pulmonary veins, making it ideal for infants and adults with multiple small, separate pulmonary veins, and multiple anatomic configurations. Early outcomes are encouraging, with complete relief of presenting symptoms and unobstructed pulmonary veins. Longer-term follow-up is needed. ${ }^{\text {E64 }}$

Repair when the pulmonary veins are distant from the left atrium is challenging, and may eventuate in a higher prevalence of pulmonary or inferior caval venous stenosis, or intracardiac baffle obstruction. $^{3-5,13, \mathrm{E} 62-\mathrm{E} 64, \mathrm{E} 67, \mathrm{E} 72}$

A myriad of surgical techniques have been described for managing distant anomalous pulmonary veins, including mobilization and direct implantation into the left atrium, use of interposition grafts, and creation of an intra-atrial baffle $f$ through a pre-existing or newly constructed atrial septal defect. ${ }^{3-5, \mathrm{E} 22, \mathrm{E} 71, \mathrm{E} 72}$ The risk of postoperative obstruction increases with circular direct anastomoses, acute angulation of veins, the requirement for increased mobilization, and handling or clamping at the time of surgery. ${ }^{3-5,13, E 62-\mathrm{E} 64, \mathrm{E} 67, \mathrm{E} 72}$

Although the pericardial tunnel, or "sutureless", technique as described by Sun and colleagues addresses several drawbacks that increased risk of pulmonary venous obstruction of other techniques, it is difficult to apply in cases of marked right-sided positioning of the heart, and hypoplasia of the right lung. ${ }^{\text {E69 }}$ Lugones and associates described a modification of their original rerouting technique using the sutureless concept, along with repositioning of the atrial septum. ${ }^{\mathrm{E} 10, \mathrm{E} 67}$ Since the vertical form of scimitar vein is shorter than the horizontal form and have sharper angulations to the inferior caval vein and are located distal to the atrial wall, the tunnel technique minimizes anastomotic tension and is the preferable option. ${ }^{\text {E10,E69 }}$ The tunnel technique has shortcomings, nonetheless, including bleeding due to tissue friability, especially in infants, and injury to the phrenic. ${ }^{\text {E67 }}$ For horizontal variety of scimitar vein, a pericardial tunnel might compromise the morphology of the scimitar vein and cause obstruction. Thus, direct implantation is more reasonable for horizontal scimitar veins. ${ }^{\mathrm{E} 67}$

Opinion is divided regarding the approach to aortopulmonary collateral arteries. ${ }^{\text {E21,E22 }}$ While some have demonstrated the beneficial effects of coil embolization on reduction of pulmonary hypertension and congestive heart failure, others have an inconsistent experience. ${ }^{11,12, \mathrm{E} 2, \mathrm{E} 4, \mathrm{E} 20-\mathrm{E} 46}$ The majority recommends coil embolization in symptomatic neonates and infants to delay surgery. ${ }^{\text {E21,E22 }}$ Our analysis from published 
series demonstrates that seven-tenths of infants had such aortopulmonary collaterals, and half underwent coil occlusion. ${ }^{3-5, \mathrm{E} 60, \mathrm{E} 72}$ Surgery was delayed until after infancy in half of those undergoing coil occlusion. Such occlusion may postpone, or even eliminate, the need for surgical repair in the absence of concomitant hemodynamically significant cardiac lesions. ${ }^{3-5,9,11,12, \mathrm{E} 2}$

Prevention and treatment of postoperative pulmonary venous stenosis remains a formidable surgical challenge. It may progress from proximal obstruction to peripheral pulmonary veins, a phenomenon appropriately termed by Caldarone and colleagues as "relentless". Postoperative pulmonary venous obstruction is more common among patients with pre-existing obstruction, and distantly located scimitar vein. The "sutureless" technique has been used in handling these patients with variable success. ${ }^{\text {E62-E64,E72 }}$ Surgical and percutaneous intervention for pulmonary of inferior caval venous obstruction have been reported with poor results. ${ }^{\mathrm{E} 34, \mathrm{E} 61, \mathrm{E} 72}$

Presently, right pulmonary lobectomy, or more rarely a right pneumectomy, has been limited for severe right pulmonary hypoplasia, recurrent upper respiratory tract infections unresponsive to medical treatment, diffuse bronchiectasis, persistent hemoptysis, or intra-atrial baffles thrombosis after corrective surgery. ${ }^{3-5,13, E 15-E 18, E 72}$

Some investigators, in the setting of a functionally univentricular heart and severely hypoplastic pulmonary arteries, and for those with post-repair persistent pulmonary hypertension, have recommended lung transplantation. ${ }^{9, \text { E19 }}$

There is an incidence of up to $11 \%$ paralysis of the phrenic following surgery. ${ }^{\mathrm{E} 6 \text {,E67 }}$ It is generally higher following direct reimplantation compared to use of an intra-atrial baffle., ${ }^{4,5}, \mathrm{E} 72$ The higher incidence in younger patients has been attributed to dissection of scimitar vein and pericardium near the right phrenic nerve. ${ }^{3-5,11,12, \mathrm{E} 6, \mathrm{E} 67, \mathrm{E} 72}$

\section{Study Limitations}

Our analysis was limited because of its retrospective nature, the rarity of the syndrome, the variety of surgical techniques used, and the long time period of the study. Radiological imaging was not routinely performed in all patients at follow-up and the incidence of undiagnosed occlusion/stenosis of the rechanneled pulmonary vein is unknown.

\section{Conclusions}

On the basis of our review, we conclude that surgical correction is recommended in all symptomatic patients, and in asymptomatic patients with pulmonary over- circulation or with a clinically treated pulmonary hypertension, stenosis of the scimitar vein, and concomitant cardiac lesions. Surgery in adults, although debatable, is recommended in symptomatic patients with pulmonary over-circulation.

Outcomes of intracardiac baffling have been disappointing; especially in infants. Direct reimplantation of the scimitar vein, although successful in small series with short-term follow-up, remains associated with an undesirable incidence of pulmonary venous obstruction. It may, nonetheless, be a desirable option in horizontal scimitar veins. Other ingenious techniques exist for those with features such as a vertical scimitar vein, severe hypoplasia of the right lung, extreme rightward positioning of the heart, and short scimitar veins. Knowledge of all these approaches should contribute to the armamentarium of cardiac surgeon faced with this rare congenital anomaly.

\section{Author's contribution}

\begin{tabular}{lllll}
\hline Author's name & Concept/ design & Data analysis / interpretation & Drafting article & Critical revis \\
\hline Ujjwal Kumar Chowdhury & $?$ & $?$ & $?$ & $?$ \\
Robert H. Anderson & $?$ & $?$ & $?$ & $?$ \\
Lakshmi Kumari Sankhyan & $?$ & $?$ & $?$ & $?$ \\
Niwin George & $?$ & $?$ & $?$ & $?$
\end{tabular}




\begin{tabular}{lllll}
\hline Author's name & Concept/ design & Data analysis/ interpretation & Drafting article & Critical revis \\
\hline Niraj Nirmal Pandey & - & $?$ & $?$ & $?$ \\
Abhinavsingh Chauhan & - & $?$ & $?$ & $?$ \\
Yatin Arora & - & $?$ & $?$ & $?$ \\
Shikha Goja & - & $?$ & $?$ & $?$ \\
\hline
\end{tabular}

\section{References}

1. Cooper G. Case of malformation of the thoracic viscera consisting of imperfect development of the right lung and transposition of the heart. London Med Gaz 1836; 18: 600-1.

2. Chasinat R. Observation d'anomalies anatomiques: remarquables de l'appareil circulatoire, avec hepatocele congenitale n'ayant donne lieu pendant la vie a aucun symptome particulier. Arch Gen Med 1836; 11: 80-91.

3. Vida VL, Padalino MA, Boccuzzo G, et al. Scimitar syndrome - European Congenital Heart Surgeons Association (ECHSA) multicentric study. Circulation 2010; 122: 1159-66.

4. Vida VL, Padrini M, Boccuzzo G, et al. Natural history and clinical outcome of "uncorrected" scimitar syndrome patients: a multicenter study of the Italian Society of Pediatric Cardiology. Rev Esp Cardiol (Engl Ed) 2013; 66: 556-560.

5. Vida VL, Guariento A, Milanesi O, et al. The natural history and surgical outcome of patients with scimitar syndrome: a multi-center European study. European Heart Journal 2018; 39: 1002-1011.

6. Mardini MK, Sakati NA, Nyhan WL. Anomalous left pulmonary venous drainage to the inferior vena cava and through the pericardiophrenic vein to the inominate vein: left-sided scimitar syndrome. Am Heart J 1981; 101: 860-862.

7. Juraszek AL, Cohn H, Van Praagh R, Van Praagh S. Isolated left-sided scimitar vein connecting all left pulmonary veins to the right inferior vena cava. Pediatr Cardiol 2005; 26: 846-847.

8. Farnsworth SG Sauerk, Buhlmery K. The spectrum of scimitar syndrome.J Thorac Cardiovasc Surg.1974; 68: 37-42.

9. Gao YA, Burrows PE, Benson LN, et al. scimitar syndrome in infancy. J Am Coll Cardiol 1993; 22: 873-882.

10. McBride ME, Huddleston CB, Balzer DT, et al. Hypoplastic left heart associated with scimitar syndrome. Pediatr Cardiol 2009; 30: 1037-8.

11. Dupuis C, Charaf LAC, Breviere G, Abou P. "Infantile" form of the scimitar syndrome with pulmonary hypertension. Am J Cardiol 1993; 71: 1326-30.

12. Dupuis C, Charaf LA, Breviere GM, et al. The "adult" form of the scimitar syndrome. Am J Cardiol 1992; 70: 502-507.

13. Wang H, Kalfa D, Rosenbaum MS, et al. Scimitar syndrome in children and adults: Natural history, outcomes, and risk analysis. Ann Thorac Surg 2018; 105(2): 592-598.

14. Tjang YS, Blanz U, Kirana S, Korfer R. Scimitar syndrome presenting in adults. J Card Surg. 2008; 23: $71-2$.

15. Halasz NA, Halloran KH, Liebow AA. Bronchial and arterial anomalies with drainage of the right lung into the inferior vena cava. Circulation 1956; 14: 826- 46.

16. Neill CA, Ferenca C, Sabiston DC. The familial occurrence of hypoplastic right lung with systemic arterial supply and venous return, "scimitar syndrome". Bull Johns Hopkins Hosp 1960; 107: 1-21.

17. Drake EH, Lynch JP.Bronchiectasis associated with anomaly of the right pulmonary vein and right diaphragm: Report of a case.J Thorac Surg.1950; 19: 433-437.

18. Kirklin JW, Ellis FH Jr, Wood WH. Treatment of anomalous pulmonary venous connection in association with interatrial communications. Surgery 1956; 39: 389-98.

19. Najm HK, Williams WG, Coles JG, et al. Scimitar syndrome: twenty years' experience and results of repair. J Thorac Cardiovasc Surg 1996; 112: 1161-8.

20. Canter CE, Martin TC, Spray TL, et al. Scimitar syndrome in childhood. Am J Cardiol 1986; 58: $652-654$. 


\section{References (Scimitar syndrome) - Electronics}

E1. Honey M. Anomalous pulmonary venous drainage of right lung to inferior vena cava 'scimitar syndrome': clinical spectrum in older patients and role of surgery. Q J Med 1977; 46: 463-83.

E2. Huddleston CBC, Exil VV, Canter CEC, Mendeloff ENE. Scimitar syndrome presenting in infancy. Ann Thorac Surg 1998; 67: 154-60.

E3. Bailey CP, Bolton HE, Jamison WL, Neptune WB. Atrioseptopexy for interatrial septal defects. J Thorac Surg.1953; 26: 184-219.

E4. Shumacker HB, Judd D. Partial anomalous pulmonary venous return with reference to drainage into the inferior vena cava and to an intact atrial septum. J Cardiovasc Surg 1964; 5: 271- 8.

E5. Torres AR, Dietl CA. Surgical management of the scimitar syndrome: an age-dependent spectrum. Cardiovasc Surg 1993; 1: 432-8.

E6. Brink J, Yong MS, D'Udekem Y, et al. Surgery for scimitar syndrome: the Melbourne experience. Interact Cardiovasc Thorac Surg 2015; 20: 31-34.

E7. Brown JW, Ruzmetov M, Minnich DJ, et al. Surgical management of scimitar syndrome: an alternative approach. J Thorac Cardiovasc Surg 2003; 125: 238-45.

E8. Yilmaz M, Senkaya I, Cengiz M. Direct reimplantation technique via a right minithoracotomy for scimitar syndrome: a case report. Heart Surg Forum 2006; 9: 843-5.

E9. Lam TT, Reemtsen BL, Starnes VA, et al. A novel approach to the surgical correction of scimitar syndrome. J Thorac Cardiovasc Surg 2007; 133: 573-4.

E10. Lugones I, Garcia R. A new surgical approach to scimitar syndrome. Ann Thorac Surg 2014; 97: 353-355.

E11. Calhoun RF, Mee RBB. A novel operative approach to scimitar syndrome. Ann Thorac Surg. 2003; 76: 301-3.

E12. Zubiate P. Surgical correction of anomalous pulmonary venous connec- tion. Ann Surg 1962; 156: 234-50.

E13. Puig-Massana M, Revuelta JM. A new technique in the correction of partial anomalous pulmonary venous drainage. J Thorac Surg. 1972; 64: 108-13.

E14. Chan DYL, et al. Adult scimitar Syndrome: A Surgical Approach. Heart, Lung and Circulation. 2015; http: //dx.doi.org/10.1016/j.hlc.2015.01.020.

E15. Laros CD, Westermann CJ. Dilatation, compensatory growth, or both after pneumonectomy during childhood and adolescence: a thirty-year follow-up study. J Thorac Cardiovasc Surg 1987; 93: 570-6.

E16. Stiles QR, Meyer BW, Lindesmith GG, Jones JC. The effects of pneumonectomy in children. J Thorac Cardiovasc Surg 1969; 58: 394-400

E17. Schramel FM, Westermann CJ, Knaepen PJ, et al: The scimitar syndrome: clinical spectrum and surgical treatment Eur Respir J 1995; 8: 196-201.

E18. Salazar J. Scimitar syndrome: Five cases examined with two-dimensional and Doppler echocardiography.Pediatr Cardiol.1995; 16: 283- 86.

E19. Eckhauser AW, O'Byrne ML, Weinberg PM, et al. Hypoplastic left ventricle and scimitar syndrome. Ann Thorac Surg 2013; 96: 2232-4.

E20. Dickinson DF, Galloway RW, Massey R, et al. Scimitar syndrome in infancy. Role of embolisation of systemic arterial supply to right lung. Br Heart J 1982; 47: 468-72. 
E21. Uthaman B, Abushaban L, Al-Qbandi M, et al. The impact of interruption of anomalous arterial supply on scimitar syndrome presenting during infancy. Catheter Cardiovasc Interv 2008; 71: 671-8.

E22. Dusenbery SM, Geva T, Seale A, et al. Outcome predictors and implications for management of scimitar syndrome. Am Heart J 2013; 165: 770-7.

E23. Driscoll DJ, Hesslein PS, Mullins CE. Congenital stenosis of individual pulmonary veins: clinical spectrum and unsuccessful treatment by transvenous balloon dilation. Am J Cardiol 1982; 49: 1767-72.

E24. Espinola-Zavaleta NN, Játiva-Chávez SS, Muñoz-Castellanos LL, Zamora-González CC. Clinical and echocardiographic characteristics of scimitar syndrome. Rev Esp Cardiol 2006; 59: 284-8.

E25. Tomsick TA, Moesner SE, Smith WL Jr. The congenital pulmonary venolobar syndrome in three successive generations. J Assoc Can Radiol 1976; 27: 196-9.

E26. Ruggieri M, Abbate M, Parano E, et al: Scimitar vein anomaly with multiple cardiac malformations, craniofacial, and central nervous system abnormalities in a brother and sister: Familial scimitar anomaly or new syndrome: Am J Med Genet 2003; 116: 170-175.

E27. Goodwin DJD, Tarver RD. Scimitar syndrome: four new cases examined with CT. Radiology 1986; 159: $15-20$.

E28. Kiely I, Filler J, Stone S, Doyle EF. Syndrome of anomalous venous drainage of the right lung to the inferior vena cava: a review of 67 reported cases and three new cases in children. Am J Cardiol 1967: 20: $102-16$

E29. Geggel RL. Scimitar syndrome associated with partial anomalous pulmonary venous connection at the supracardiac, cardiac, and infracardiac levels. Pediatr Cardiol 1993; 14: 234-7.

E30. Morgan JR, Forker AD. Syndrome of hypoplasia of the right lung and dextroposition of the heart: "scimitar sign" with normal pulmonary venous drainage. Circulation 1971; 43: 27-30.

E31. Gikonyo DK, Tandon R, Lucas RV Jr, Edwards JE. Scimitar syndrome in neonates: report of four cases and review of the literature. Pediatr Cardiol 1986; 6: 193-197.

E32. Jimenez M, Hery E, VanDoesburg NH, Guerin R, Spier S. Inferior vena cava stenosis in scimitar syndrome: a case report. J Am Soc Echocardiogr 1988; 1: 152-4.

E33. Co-Vu JG, Kirkpatrick EC, Samyn MM. A rare case of hypoplastic left heart syndrome and scimitar syndrome: value of neonatal cardiac magnetic resonance imaging. Pediatr Cardiol 2010; 31: 739-40.

E34. Farnsworth AE, Ankeney JL. The spectrum of the scimitar syndrome. J Thorac Cardiovasc Surg 1974; 68: $37-42$.

E35. Kamiyama M, Kamata S, Usui N. Scimitar syndrome treated with pneumonectomy: a case associated with bronchospastic attack. Pediatr Surg Int. 2004; 20: 65-6.

E36. Lloyd IE, Rowe LR, Erickson LK, et al. Two cases of scimitar syndrome associated with multiple congenital skeletal anomalies and lacking abnormalities by genomic microarray analysis. Pediatr Dev Pathol 2014; 17: 360-5.

E37. Kirks DR, Kane PE, Free EA, Taybi H. Systemic arterial supply to normal basilar segments of the left lower lobe. AJR 1976; 126: 817-21.

E38. Perry SB, Radtke 6V, Fellows KE, Keane JF, Lock JE . Coil embolization to occlude aortopulmonary collateral vessels and shunts in patients with congenital heart disease. J Am Cull Cardiol 1989; 13: 100-8 .

E39. Currarino G, Willis K, Miller W. Congenital fistula between an aberrant systemic army and a pulmonary vein without sequestration. J Pediatr 1975; 87: 554-7. 
E40. Pfammater JP: Infantile Scimitar syndrome with pulmonary hypertension-Successful treatment with coil embolization. Cardiol Young 1997; 7: 454-457.

E41. Clements BS, Warner JO. Pulmonary sequestration and related congenital bronchopulmonary-vascular malformations: nomenclature and classification based on anatomical and embryological considerations. Tho$\operatorname{rax} 1987 ; 42:$ 401-8.

E42. Frank JL, Poole CA, Rosas G . Horseshoe lung: clinical, pathologic and radiologic features and a new plain film finding. AJI 1986; 146: 217-25.

E43. Pawass ND, Badawi MG, Fatani JA, Meshari AA, Edrees YB . Horseshoe lung with multiple congenital anomalies. Acta Radiol 1987; 28: 751-4 .

E44. Chemin A, Bonnet D, Bourgeois ML, et al. Respiratory outcome in children with scimitar syndrome. J Pediatr 2013; 162: 275-79

E45. Long WA. Structural cardiovascular abnormalities presenting as persistent pulmonary hypertension of newborn. Clin Perinatol 1984; 2: 601-26.

E46. Haworth SG, Sauer U, Bühlmeyer K. Pulmonary hypertension in scimitar syndrome in infancy. Br Heart J 1983; 50: 182-9.

E47. Mas C, Goh TH, Wilkinson JL. New interventional therapeutic approach for dual drainage of the scimitar vein. Catheter Cardiovasc Interv 2000; 51: 192-5.

E48. Idris MT. Diagnostic Aid of transesophageal echocardiography in an adult case of scimitar syndrome: Confirmation of the findings at surgery and review of the literature. J Am Soc Echocardiogr 1998; 11: 387-92.

E49. Goodman LR, Jamshidi A, Hipona FA. Meandering right pulmonary vein simulating the scimitar syndrome.Chest.1972; 62: 510-12.

E50. Gudjonsson U, Brown JW. Scimitar syndrome. Semin Thorac Cardiovasc Surg Pediatr Card Surg Annu 2006; 9: 56-62.

E51. Oakley D, Naik D, Verel D, Rajan S. Scimitar vein syndrome: report of nine new cases. Am Heart J 1984; 107: 596-8.

E52. Shibuya K, Smallhorn JE, McCrindle BW. Echocardiographic clues and accuracy in the diagnosis of scimitar syndrome. J Am Soc Echocardiogr 1996; 9: 174-81

E53. Huebsch P, Neuhold A, Mayr H, Glogar D. Anomalous pulmonary venous drainage shown by duplex sonography, computed tomography, and plain radiography. Thorax 1989; 44: 63-5.

E54. Trigaux JP, Marchandise B, Schoevaerdts JC, Kremer R, Chalant CH. Partial abnormal infradiaphragmatic pulmonary venous connection visualized by two-dimensional abdominal ultrasonography. J Clin Ultrasound 1984; 12: 425-8.

E55. Sinha R, Singh P, Bhatnagar AK, Batra A. Scimitar syndrome: imaging by magnetic resonance angiography and Doppler echocardiography. Indian J Chest Dis Allied Sci. 2004; 46: 283-6.

E56. Hausman D, Daniel WG, Mugge A, et al. Value of transesophageal color Doppler echocardiography for detection of different types of atrial septal defect in adults. J Am Soc Echocardiogr 1992; 5: 481-8.

E57. Kramer U, Dornberger V, Fenchel M, et al: Scimitar syndrome: Morphological diagnosis and assessment of hemodynamic significance by magnetic resonance imaging. Eur Radiol 2003; 13: L147-L150.

E58. Baran R, Kir A, Meltem Tor M, Ozvaran K, Tunaci A. Scimitar syndrome: confirmation of diagnosis by a noninvasive technique (MRI). Eur Radiol 1996; 6: 92-4.

E59. Baxter R, McFadden PM, Gradman M, Wright A. Scimitar syndrome: cine magnetic resonance imaging demonstration of anomalous pulmonary venous drainage. Ann Thorac Surg 1990; 50: 121-3. 
E60. Benito Bartolome F, Gonzalez Garcia A, Oliver Ruiz JM. Intraluminal dilation of inferior vena cava stenosis after repair of the scimitar syndrome in an adult patient. Rev Esp Cardiol. 2002; 55(2): 190-2.

E61. Masrani A, McWilliams S, Bhalla S, Woodard P. Anatomical associations and radiological characteristics of scimitar syndrome on CT and MR. Journal of Cardiovascular Computed Tomograph (2018), doi: 10.1016/j.jcct.2018.02.001.

E62. Najm HK, Caldarone CA, Smallhorn J, Coles JG. A sutureless technique for the relief of pulmonary vein stenosis with the use of in situ pericardium. J Thorac Cardiovasc Surg. 1998; 115: 168-170.

E63. Najm HK. The bad guy, good guy scenario with a scimitar sword: a case to learn from. J Thorac Cardiovasc Surg. 2016; 152: e107-e108.

E64. Najm HK, Ahmad M, Salam Y, Klein J, Hasan SM, Majdalany D, et al. Early outcomes for in si$\mathrm{tu}$ pericardial roll repair for distant anomalous pulmonary venous return. Ann Thorac Surg 2020 (https://doi.org/10.1016/j.athoracsur.2020.03.063)

E65. Kowatari R, Suzuki Y, Daitoku K, Hattori K, Fukuda I. A novel surgical procedure for scimitar syndrome: scimitar vein with right atrium and inferior vena cava wall flap. J Card Surg 2016; 9999: 1-3.

E66. Jensen H, Muthialu N, Furci B, Yates R, Kostolny M, Tsang V. Direct implantation of scimitar vein to the left atrium via sternotomy: a reappraisal. European Journal of Cardio-Thoracic Surgery 2014; 45: 1066-1069

E67. Lugones I, Biancolini MF, Zerpa Pacheco VE, Martı'nez IA, Damsky Barbosa JMM, de Dios AMS. Modified in situ pericardial rerouting technique for scimitar syndrome repair. World J Pediatr Congenit Heart Surg 2017;8:735-9.

E68. Geggel RL, Gauvreau K, Callahan R, Feins EN, Baird CW. Scimitar syndrome: A new multipatch technique and incidence of postoperative pulmonary vein obstruction. JTCVS Techniques 2020; 4: 208-216.

E69. Sun Y, Zhang H, Liu J, X Z, Wang S, Zhu H. Pericardial tunnel technique in the surgical management of the vertical form of scimitar syndrome. Interactive Cardiovascular and Thoracic Surgery 2018; 1-7.

E70. Guerra NC, Pernot M, Nesseris G, Al-Yamani M, Roques X, Thambo JB, Kreitmann B, Roubertie F. Scimitar syndrome repair in adults: Intermediate-term results using an extracardiac conduit. Ann Thorac Surg 2016; 102: 2070-2076.

E71. Alsoufi B. The pericardial tunnel technique might produce optimal morphological repair of the scimitar syndrome. Interactive Cardiovasc Thorac Surg. 2018; 27: 393-394.

E72. Vida VL, Guariento A. A sword threatening the heart: The scimitar syndrome. JTCVS Techniques 2020; $1: 75-80$.

\section{Figure Legends}

Figure 1 : Coronal maximum intensity projection image (A) and volume rendered image, anterior view (B) show an anomalous vein $\left(^{*}\right)$ draining the venous return of the right lung into the suprahepatic inferior vena cava (IVC). Volume rendered image, posterior view (C) demonstrates an anomalous systemic artery (arrowheads) from abdominal aorta supplying the lower lobe of right lung.

Figure 2 : Oblique coronal maximum intensity projection image (A) and volume rendered images, anterior view (B) and posterior view (C) shows an anomalous vein (*) draining the venous return of the right lung into the suprahepatic inferior vena cava (IVC). Note is made of tight stenosis (white arrow) of the anomalous vein just before draining into the IVC.

Figure 3 : Schematic drawing of Shumacker and Judds modification of repair of scimitar syndrome. After transecting the scimitar vein with a caval cuff, the proximal end of the scimitar vein was transplanted to the posterolateral wall of the right atrium (RA) adjacent to a pre-existing atrial septal defect (ASD). A short 
segment of polytetrafluoroethylene patch was used to baffle flow across the scimitar vein and ASD to left atrium (LA).

Figure 4 : Indiana University (Brown's) modification. Through a right thoracotomy, the scimitar vein was transected with a vena caval cuff. After spatulating, the proximal end of the scimitar vein was translocated into the LA using a side biting clamp without CPB.

Figure 5 : Lam's technique of repair of scimitar syndrome for short scimitar vein. Under CPB, after transecting the scimitar vein, a segment of polytetrafluoroethylene graft was used for anastomosis between the scimitar vein and LA.

Figure 6A-6C : Step-by-step demonstration of division and translocation of the scimitar vein into the LA via pericardial tunnel (Lugones and Garcia's modification). 6A: After resecting the scimitar vein, both ends were over sewn. 6B: A large incision was made in the right lateral wall of the pericardium and the scimitar vein was anastomosed to the pericardium. $6 \mathrm{C}$ : Under circulatory arrest, a large vertical left atriotomy was performed. The pericardium was sutured to the left atriotomy and free wall of the RA.

Figure 7A,7B : Calhoun and Mee's modification of repair of scimitar syndrome. 7A: Under circulatory arrest after transecting the inferior cavoatrial junction, a pericardial patch was used to partition the IVC into anterior and posterior compartments in patients with short, lung-enveloped scimitar veins. 7B: After incising the inferior aspect of LA, and interatrial septum, the posterior half of the IVC containing the scimitar vein was sutured to the LA and the anterior lip of IVC was sewn to the RA.

Figure 8A,8B : 8A: An artist's rendition of the anomalous scimitar vein (SV) entering the IVC below the diaphragm above the hepatic veins. 8B: The scimitar vein was directed from the orifice in the IVC to the LA through the ASD. The right atriotomy was extended downwards into the inferior cavoatrial junction for adequate exposure and the requirement of patch augmentation, if needed. Under circulatory arrest, a large synthetic or pericardial patch was sutured from the caudal end of the opening of the scimitar vein all around the margin of the ASD to complete the repair.

Figure 9 : Kowatari's technique of repair of scimitar syndrome using the walls of the right atrium and IVC as a flap, and anastomosing directly to the LA under CPB and cold crystalloid cardioplegic protection.

Figure 10 : Gurerra's modification of repair of scimitar syndrome. Under normothermic CPB and cardioplegic myocardial protection, the scimitar vein was disconnected from the IVC. The IVC was repaired by a continuous suture. The scimitar vein was anastomosed end-to-end to the ringed ploytetrafluoroethylene conduit. The reinforced conduit was tunneled behind the IVC and was anastomosed to the postero inferior LA wall.

[Abbreviations: D: Diaphragm; HV: Hepatic veins; P: Pericardium; PA: Pulmonary artery; PTFE: Polytetrafluoroethylene; SVC: Superior caval vein]

Table E1: Summary of the published investigations documenting the diagnosis of anomalous connection of the right superior caval vein to the morphologically left atrium and its management 


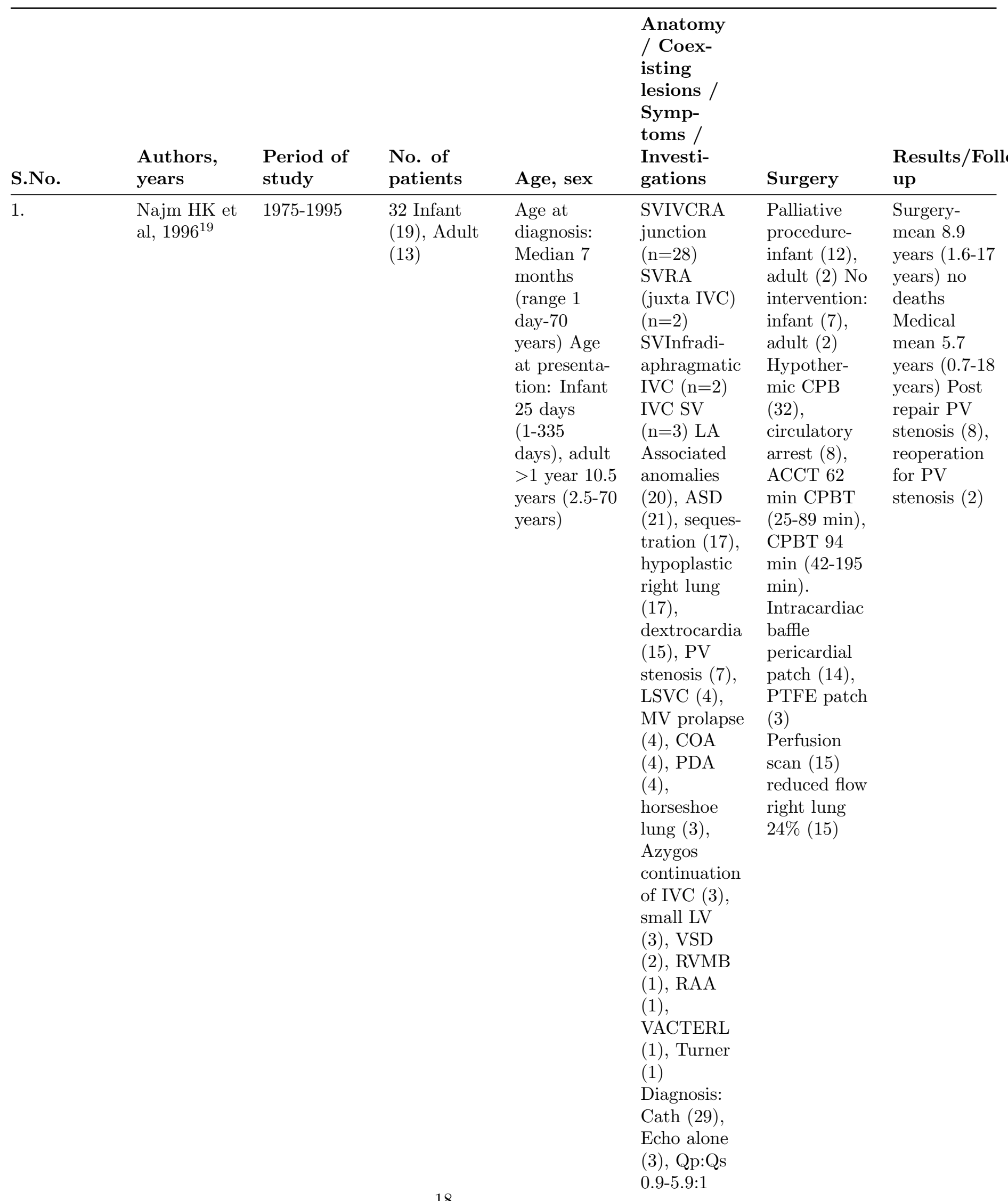




\begin{tabular}{|c|c|c|c|c|c|c|c|}
\hline S.No. & $\begin{array}{l}\text { Authors, } \\
\text { years }\end{array}$ & $\begin{array}{l}\text { Period of } \\
\text { study }\end{array}$ & $\begin{array}{l}\text { No. of } \\
\text { patients }\end{array}$ & Age, sex & $\begin{array}{l}\text { Anatomy } \\
\text { / Coex- } \\
\text { isting } \\
\text { lesions / } \\
\text { Symp- } \\
\text { toms / } \\
\text { Investi- } \\
\text { gations }\end{array}$ & Surgery & $\begin{array}{l}\text { Results/Foll } \\
\text { up }\end{array}$ \\
\hline 2. & $\begin{array}{l}\text { Huddleston } \\
\text { CB et al, } \\
1999^{\mathrm{E} 2}\end{array}$ & $1972-1997$ & 12 & $\begin{array}{l}\text { Age at pre- } \\
\text { sentation: } \\
\text { mean } 6 \\
\text { weeks ( } 2 \\
\text { days-4 } \\
\text { months) } \\
\text { Female } 4\end{array}$ & $\begin{array}{l}\text { SV infradi- } \\
\text { aphragmatic } \\
\text { IVC (8) IVC } \\
\text { infradi- } \\
\text { aphramatic } \\
\text { (4) SV LA } \\
\text { Hypoblastic } \\
\text { right lung } \\
(12), \\
\text { tracheal } \\
\text { stenosis (1), } \\
\text { shones } \\
\text { complex (1) } \\
\text { Clinical: } \\
\text { Tachypb- } \\
\text { noea CHF } \\
(12), \text { NEC } \\
(1), \text { HMD } \\
(1), \\
\text { cyanosis, } \\
\text { high PVR, } \\
\text { rightleft } \\
\text { shunt (1) } \\
\text { PAP } \\
\text { systolic: } \\
73.9 \pm 21.8 \\
\text { mmHg (40- } \\
110 m m H g) \\
\text { Qp:Qs } \\
3.1 \pm 1.5: 1 \\
\text { (1) }\end{array}$ & $\begin{array}{l}\text { Hypothermic } \\
\text { circulatory } \\
\text { arrest (12), } \\
\text { intra-atrial } \\
\text { baffling (2), } \\
\text { divi- } \\
\text { sion+transloca } \\
\text { to LA or RA } \\
\text { with baffle } \\
(5), \text { pneu- } \\
\text { monectomy } \\
(4) \text { for baffle } \\
\text { obstruction, } \\
\text { coil } \\
\text { embolization } \\
\text { MAPCAs } \\
(2), \text { bilateral } \\
\text { lung trans- } \\
\text { plantation } \\
(2), \text { medical } \\
\text { treatment } \\
(2),\end{array}$ & $\begin{array}{l}\text { Overall } \\
\text { mortality (4) } \\
\text { Follow-up } \\
\text { median } 8.8 \\
\text { years, post } \\
\text { pneumonectom } \\
\text { tionimary } \\
\text { proce- } \\
\text { dure/baffle } \\
\text { occlusion - } \\
\text { survivors } \\
\text { doing well }\end{array}$ \\
\hline
\end{tabular}




\begin{tabular}{|c|c|c|c|c|c|c|c|}
\hline S.No. & $\begin{array}{l}\text { Authors, } \\
\text { years }\end{array}$ & $\begin{array}{l}\text { Period of } \\
\text { study }\end{array}$ & $\begin{array}{l}\text { No. of } \\
\text { patients }\end{array}$ & Age, sex & $\begin{array}{l}\text { Anatomy } \\
\text { / Coex- } \\
\text { isting } \\
\text { lesions / } \\
\text { Symp- } \\
\text { toms / } \\
\text { Investi- } \\
\text { gations }\end{array}$ & Surgery & $\begin{array}{l}\text { Results/Foll } \\
\text { up }\end{array}$ \\
\hline 3. & $\begin{array}{l}\text { Brink J et } \\
\text { al, } 2015^{\mathrm{E} 6}\end{array}$ & $1974-2012$ & 21 & $\begin{array}{l}\text { Age at } \\
\text { operation: } \\
\text { Median } 5.4 \\
\text { years }(2.5 \\
\text { months-16.7 } \\
\text { years) } \\
\text { Female }(10)\end{array}$ & $\begin{array}{l}\text { SVIVC ASD } \\
(11), \text { VSD } \\
(1), \\
\text { ASD+VSD } \\
(1), \text { VSD, } \\
\text { PDA(1), } \\
\text { lung seques- } \\
\text { tration (1), } \\
\text { MAPCA } \\
(13), \\
\text { hypoplastic } \\
\text { right lung } \\
(16)\end{array}$ & $\begin{array}{l}\text { CPB (19), } \\
\text { non-CPB } \\
(2), \\
\text { sternotomy } \\
(18), \\
\text { thoracotomy } \\
(3), \text { baffle } \\
\text { repair (15), } \\
\text { reimplanta- } \\
\text { tion to RA } \\
(4), \text { to LA } \\
(1), \text { pneu- } \\
\text { monectomy } \\
(1), \\
\text { concomitant } \\
\text { ICR (15), } \\
\text { ACCT } \\
79 \pm 37.5 \text { min } \\
(29-164 \\
\text { min), CPBT } \\
115.2 \pm 51.5 \\
\text { min (52-263 } \\
\text { min), } \\
\text { circulatory } \\
\text { arrest (11), } \\
\text { mean arrest } \\
\text { time } 28.5 \\
\text { min (19-50 } \\
\text { min) }\end{array}$ & $\begin{array}{l}\text { Hospital } \\
\text { death }(1), \\
\text { late death } \\
(3), \\
\text { suprasys- } \\
\text { temic PAP } \\
\text { postoperative- } \\
\text { died (2), } \\
\text { mean } \\
\text { follow-up } \\
\text { 13.7 } \pm 10.3 \\
\text { years } \\
\text { (1.3-38.5 } \\
\text { years), all } \\
\text { survivors } \\
\text { NYHA I, Nil } \\
\text { medications }\end{array}$ \\
\hline
\end{tabular}




\begin{tabular}{|c|c|c|c|c|c|c|c|}
\hline S.No. & $\begin{array}{l}\text { Authors, } \\
\text { years }\end{array}$ & $\begin{array}{l}\text { Period of } \\
\text { study }\end{array}$ & $\begin{array}{l}\text { No. of } \\
\text { patients }\end{array}$ & Age, sex & $\begin{array}{l}\text { Anatomy } \\
\text { / Coex- } \\
\text { isting } \\
\text { lesions / } \\
\text { Symp- } \\
\text { toms / } \\
\text { Investi- } \\
\text { gations }\end{array}$ & Surgery & $\begin{array}{l}\text { Results/Foll } \\
\text { up }\end{array}$ \\
\hline 4. & $\begin{array}{l}\text { Gao YA et } \\
\text { al, } 1993^{9}\end{array}$ & $1964-89$ & 13 & $\begin{array}{l}\text { Age at } \\
\text { catheteriza- } \\
\text { tion: } 1 \text { day- } 6 \\
\text { months } \\
(78 \pm 74 \\
\text { days }), \\
\text { Female (8) }\end{array}$ & $\begin{array}{l}\text { SVIVC } \\
\text { Pulmonary } \\
\text { hypoplasia } \\
(12), \\
\text { associated } \\
\text { cardiac mal- } \\
\text { formations } \\
(11), \\
\text { MAPCA } \\
(9), \\
\text { hypoplasia } \\
\text { left heart } \\
(7), \\
\text { bronchial se- } \\
\text { questration } \\
(2), \\
\text { horseshoe } \\
\text { lung (4), } \\
\text { CHF (11), } \\
\text { pulmonary } \\
\text { hypertension } \\
\text { (12) }\end{array}$ & $\begin{array}{l}\text { Surgery or } \\
\text { tran- } \\
\text { scatheter } \\
\text { therapy } \\
(10), \\
\text { MAPCAs- } \\
\text { surgical } \\
\text { ligation (3), } \\
\text { coil } \\
\text { embolization } \\
\text { (4), balloon } \\
\text { angioplasty } \\
\text { (2) stenosis } \\
\text { left sided } \\
\text { PV (1), } \\
\text { stenosis } \\
\text { anomalous } \\
\text { right PV } \\
\text { (1), } \\
\text { occlusion } \\
\text { MAPCAs } \\
\text { significant } \\
\text { improvement- } \\
\text { CHF, PAH } \\
\text { recurred } \\
\text { underwent } \\
\text { surgery }\end{array}$ & \\
\hline
\end{tabular}




\begin{tabular}{|c|c|c|c|c|c|c|c|}
\hline S.No. & $\begin{array}{l}\text { Authors, } \\
\text { years }\end{array}$ & $\begin{array}{l}\text { Period of } \\
\text { study }\end{array}$ & $\begin{array}{l}\text { No. of } \\
\text { patients }\end{array}$ & Age, sex & $\begin{array}{l}\text { Anatomy } \\
\text { / Coex- } \\
\text { isting } \\
\text { lesions / } \\
\text { Symp- } \\
\text { toms / } \\
\text { Investi- } \\
\text { gations }\end{array}$ & Surgery & $\begin{array}{l}\text { Results/Foll } \\
\text { up }\end{array}$ \\
\hline 5. & $\begin{array}{l}\text { Juraszek AL } \\
\text { et al, } 2005^{7}\end{array}$ & 2005 & 1 & $\begin{array}{l}22 \text { years } \\
\text { female }\end{array}$ & $\begin{array}{l}\text { ASD-OS } \\
\text { closure at } \\
\text { age } 3 \text { years } \\
\text { Decrease } \\
\text { exercise } \\
\text { tolerance, } \\
\text { CXR- mild } \\
\text { car- } \\
\text { diomegaly, } \\
\text { cath- left } \\
\text { sided } \\
\text { pulmonary } \\
\text { veins joined } \\
\text { in a } \\
\text { confluence } \\
\text { behind the } \\
\text { LA drained, } \\
\text { right sided } \\
\text { infradi- } \\
\text { aphragmatic } \\
\text { IVC, RSPV- } \\
\text { cranial part } \\
\text { of RSPVC }\end{array}$ & $\begin{array}{l}\text { Surgery: } \\
\text { side to side } \\
\text { anastomosis- } \\
\text { left } \\
\text { pulmonary } \\
\text { venous } \\
\text { confluence } \\
\text { to LA, } \\
\text { ligation and } \\
\text { division } \\
\text { SV-IVC } \\
\text { junction }\end{array}$ & $\begin{array}{l}\text { Follow-up: } 6 \\
\text { years MRI- } \\
\text { unrestricted } \\
\text { anastomosis, } \\
\text { doing well }\end{array}$ \\
\hline 6. & $\begin{array}{l}\text { Chan DYL } \\
\text { et al, } \\
2015^{\text {E14 }}\end{array}$ & 2015 & 1 & $\begin{array}{l}52 \text { years } \\
\text { female }\end{array}$ & $\begin{array}{l}\text { Clinical: } \\
\text { Increasing } \\
\text { dyspnoea, } \\
\text { fatigue, } \\
\text { CXR- large } \\
\text { vessel - right } \\
\text { border of } \\
\text { diaphragm } \\
\text { CT-SV } \\
\text { draining } \\
\text { right lung } \\
\text { infradi- } \\
\text { aphramatic } \\
\text { IVC, TEE- } \\
\text { Intact atrial } \\
\text { septum, } \\
\text { mild PAH, } \\
\text { Qp:Qs: 2.1:1 }\end{array}$ & $\begin{array}{l}\text { CPB } \\
\text { circulatory } \\
\text { arrest. } \\
\text { Right } \\
\text { pleural } \\
\text { cavity open- } \\
\text { large SV } \\
\text { draining to } \\
\text { infradi- } \\
\text { aphramatic } \\
\text { IVC Atrial } \\
\text { septectomy, } \\
\text { intra-atrial } \\
\text { baffling, } \\
\text { PTFE patch }\end{array}$ & $\begin{array}{l}\text { Follow-up } 4 \\
\text { months, } \\
\text { asymp- } \\
\text { tomatic, } \\
\text { patent } \\
\text { IVC-LA } \\
\text { baffle, } \\
\text { normal RV } \\
\text { size }\end{array}$ \\
\hline
\end{tabular}




\begin{tabular}{|c|c|c|c|c|c|c|c|}
\hline S.No. & $\begin{array}{l}\text { Authors, } \\
\text { years }\end{array}$ & $\begin{array}{l}\text { Period of } \\
\text { study }\end{array}$ & $\begin{array}{l}\text { No. of } \\
\text { patients }\end{array}$ & Age, sex & $\begin{array}{l}\text { Anatomy } \\
\text { / Coex- } \\
\text { isting } \\
\text { lesions / } \\
\text { Symp- } \\
\text { toms / } \\
\text { Investi- } \\
\text { gations }\end{array}$ & Surgery & $\begin{array}{l}\text { Results/Foll } \\
\text { up }\end{array}$ \\
\hline 7. & $\begin{array}{l}\text { Chemin A } \\
\text { et al, } \\
2013^{\mathrm{E} 23}\end{array}$ & $1976-2013$ & 81 & $\begin{array}{l}\text { Age at } \\
\text { diagnosis: } \\
<1 \text { year } \\
(67) \text {, } \\
\text { median } \\
1.5 \text { month } \\
\text { (IQR: } \\
0.1-6 \\
\text { months) }\end{array}$ & $\begin{array}{l}\text { Antenatal } \\
\text { diagnosis } \\
(6), \text { CHF } \\
(18), \text { res- } \\
\text { piratory } \\
\text { distress } \\
() 19), \\
\text { cardiac } \\
\text { murmur } \\
(8), \\
\text { incidental } \\
\text { finding } \\
\text { (7), right } \\
\text { lung } \\
\text { hypoplasia } \\
\text { (81), hy- } \\
\text { poplastic } \\
\text { RPA (57), } \\
\text { MAPCA } \\
\text { (58), ASD } \\
\text { (58), } \\
\text { vertebral } \\
\text { anomalies } \\
\text { (10), PH } \\
\text { (36), } \\
\text { death (26) }\end{array}$ & $\begin{array}{l}\text { Not } \\
\text { mentioned }\end{array}$ & $\begin{array}{l}\text { Follow-up- } \\
\text { median } \\
\text { duration } \\
7.2 \text { years } \\
(2.4-13.4), \\
\text { median } \\
\text { age at } \\
\text { follow-up } \\
9.8 \text { years } \\
(4.5-14.4), \\
\text { high respi- } \\
\text { ratory } \\
\text { morbidi- } \\
\text { ties with } \\
38 \% \text { and } \\
43 \% \\
\text { children, } \\
\text { pulmonary } \\
\text { infections / } \\
\text { wheezing, } \\
\text { one-third- } \\
\text { rehospital- } \\
\text { ized, } \\
\text { significant } \\
\text { lower } \\
\text { TLC- } \\
\text { infantile } \\
\text { variety }\end{array}$ \\
\hline
\end{tabular}




\begin{tabular}{|c|c|c|c|c|c|c|c|}
\hline S.No. & $\begin{array}{l}\text { Authors, } \\
\text { years }\end{array}$ & $\begin{array}{l}\text { Period of } \\
\text { study }\end{array}$ & $\begin{array}{l}\text { No. of } \\
\text { patients }\end{array}$ & Age, sex & $\begin{array}{l}\text { Anatomy } \\
\text { / Coex- } \\
\text { isting } \\
\text { lesions / } \\
\text { Symp- } \\
\text { toms / } \\
\text { Investi- } \\
\text { gations }\end{array}$ & Surgery & $\begin{array}{l}\text { Results/Foll } \\
\text { up }\end{array}$ \\
\hline 8. & $\begin{array}{l}\text { Wang } \mathrm{H} \text { et } \\
\text { al, } 2018^{13}\end{array}$ & 1994-2015 & 47 & $\begin{array}{l}\text { Median age } \\
\text { at heart } \\
\text { failure } 37.7 \\
\text { years- } \\
\text { isolated } \\
\text { adult }\end{array}$ & $\begin{array}{l}\text { Isolated } \\
\text { infantile (1), } \\
\text { CHD } \\
\text { infantile (2), } \\
\text { isolated } \\
\text { adult (16), } \\
\text { ASD, VSD, } \\
\text { UVH, } \\
\text { HLHS, } \\
\text { Shones } \\
\text { complex, } \\
\text { mitral } \\
\text { atresia, } \\
\text { pulmonary } \\
\text { sequestra- } \\
\text { tion, left } \\
\text { anomalous } \\
\text { pulmonary } \\
\text { vein return, } \\
\text { RPA } \\
\text { hypoplasia, } \\
\text { ALCAPA, } \\
\text { TOF, TA, } \\
\text { DORV SV } \\
\text { obstruction } \\
\text { at IVC (19, } \\
\text { 43.2\%) }\end{array}$ & $\begin{array}{l}\text { Intra-atrial } \\
\text { baffle (12), } \\
\text { reimplanta- } \\
\text { tion }(5), \\
\text { right pneu- } \\
\text { monectomy } \\
(1) \text {. Overall } \\
\text { mortality } \\
\text { baffle or } \\
\text { reimplanta- } \\
\text { tion } 37.5 \% \\
(3 \text { of } 8) \\
\text { infants, } 0 \% \\
\text { non-infants }\end{array}$ & $\begin{array}{l}\text { Coil em- } \\
\text { bolization, } \\
\text { non- } \\
\text { operatively } \\
\text { managed } \\
(28) \text {, } \\
\text { medical } \\
\text { follow-up } \\
2.74 \text { years } \\
(0.46-9.78) \text {, } \\
3 / 6 \text { infantile, } \\
4 \text { of CHD } \\
\text { infantile- } \\
\text { died At } 3.55 \\
\text { years } \\
\text { median } \\
\text { follow-up } \\
\text { living } 12 \\
\text { (80\%), died } \\
3 \text { (20\%). }\end{array}$ \\
\hline
\end{tabular}




\begin{tabular}{|c|c|c|c|c|c|c|c|}
\hline S.No. & $\begin{array}{l}\text { Authors, } \\
\text { years }\end{array}$ & $\begin{array}{l}\text { Period of } \\
\text { study }\end{array}$ & $\begin{array}{l}\text { No. of } \\
\text { patients }\end{array}$ & Age, sex & $\begin{array}{l}\text { Anatomy } \\
\text { / Coex- } \\
\text { isting } \\
\text { lesions / } \\
\text { Symp- } \\
\text { toms / } \\
\text { Investi- } \\
\text { gations }\end{array}$ & Surgery & $\begin{array}{l}\text { Results/Foll } \\
\text { up }\end{array}$ \\
\hline 9. & $\begin{array}{l}\text { Dusenbery } \\
\text { SM et al, } \\
2013^{\mathrm{E} 22}\end{array}$ & 1964-2013 & 80 & $\begin{array}{l}\text { Female }(51) \\
\text { Age at } \\
\text { diagnosis } \\
\text { (year) } 0.4 \\
(0-66.8) \text { Age } \\
\text { at follow-up } \\
\text { (year) } 10.8 \\
(0.71-5)<1 \\
\text { year }=46,> \\
1 \text { year }=34\end{array}$ & 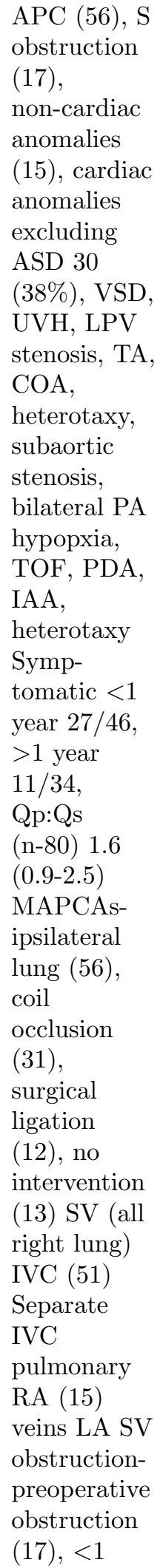 & $\begin{array}{l}\text { Not } \\
\text { mentioned }\end{array}$ & $\begin{array}{l}\text { Medical } \\
\text { follow-up } 6.2 \\
\text { years }(0.4-2 \\
\text { years)- } \\
61 / 80 \\
\text { survived SV } \\
\text { surgery was } \\
\text { performed } \\
33 / 61 \\
\text { patients, } \\
\text { postopera- } \\
\text { tive PV } \\
\text { obstruction } \\
\text { (18/36) who } \\
\text { had SV } \\
\text { surgery, } \\
13 / 28 \text { with } \\
\text { baffle } \\
\text { procedure, } \\
5 / 8 \text { with } \\
\text { reimplanta- } \\
\text { tion } \\
\text { Postopera- } \\
\text { tive SV } \\
\text { stenosis } \\
\text { occurs with } \\
\text { similar } \\
\text { frequency } \\
\text { with both } \\
\text { baffle and } \\
\text { reimplantation }\end{array}$ \\
\hline
\end{tabular}




\begin{tabular}{|c|c|c|c|c|c|c|c|}
\hline S.No. & $\begin{array}{l}\text { Authors, } \\
\text { years }\end{array}$ & $\begin{array}{l}\text { Period of } \\
\text { study }\end{array}$ & $\begin{array}{l}\text { No. of } \\
\text { patients }\end{array}$ & Age, sex & $\begin{array}{l}\text { Anatomy } \\
\text { / Coex- } \\
\text { isting } \\
\text { lesions / } \\
\text { Symp- } \\
\text { toms / } \\
\text { Investi- } \\
\text { gations }\end{array}$ & Surgery & $\begin{array}{l}\text { Results/Foll } \\
\text { up }\end{array}$ \\
\hline 10. & $\begin{array}{l}\text { Masrani A } \\
\text { et al, } \\
2018^{\mathrm{E} 61}\end{array}$ & $2001-2016$ & 16 & $\begin{array}{l}\text { Female }(13) \\
\text { Age mean } \\
39.5 \text { years } \\
\text { (14 days- } 72 \\
\text { years) } \\
\text { Pediatric } \\
\text { age } 14 \text { days, } \\
7 \text { months, } 9 \\
\text { years, - } 3 \\
\text { patients }\end{array}$ & $\begin{array}{l}\text { CT (12), } \\
\text { MRI (3), } \\
\text { CT+MRI } \\
\text { (1) SV } \\
\text { Infradi- } \\
\text { aphragmatic } \\
\text { IVC (10) SV } \\
\text { supra IVC } \\
\text { (6) Right } \\
\text { lung } \\
\text { hypoplasia } \\
\text { (9) CHD } \\
\text { (4), dex- } \\
\text { troposition } \\
\text { (8) } \\
\text { Pulmonary } \\
\text { sequestra- } \\
\text { tion (4) RV } \\
\text { enlargement- } \\
\text { most } \\
\text { common } \\
\text { radiological } \\
\text { findings }\end{array}$ & $\begin{array}{l}\text { Not } \\
\text { mentioned }\end{array}$ & $\begin{array}{l}\text { Not } \\
\text { mentioned }\end{array}$ \\
\hline 11. & $\begin{array}{l}\text { Tjang YS et } \\
\text { al, } 2008^{14}\end{array}$ & & 1 & $\begin{array}{l}19 \text { year } \\
\text { Female }\end{array}$ & $\begin{array}{l}\text { Systolic } \\
\text { murmur, no } \\
\text { recurrent } \\
\text { pneumonia, } \\
\text { ECG, RAD, } \\
\text { RVH, CXR, } \\
\text { destropso- } \\
\text { tion Qp: Qs } \\
\text { 1.8:1, No } \\
\text { ASD, } \\
\text { MRA-SVC } \\
\text { infradi- } \\
\text { aphragmatic } \\
\text { IVC }\end{array}$ & $\begin{array}{l}\text { Hypothermic } \\
\text { circulatory } \\
\text { arrest, atrial } \\
\text { septectomy, } \\
\text { baffle } \\
\text { scimitar vein }\end{array}$ & $\begin{array}{l}\text { Follow-up: } 5 \\
\text { years, } \\
\text { NYHA I } \\
\text { Echo - no } \\
\text { stenosis of } \\
\text { intra-atrial } \\
\text { tunnel }\end{array}$ \\
\hline
\end{tabular}




\begin{tabular}{|c|c|c|c|c|c|c|c|}
\hline S.No. & $\begin{array}{l}\text { Authors, } \\
\text { years }\end{array}$ & $\begin{array}{l}\text { Period of } \\
\text { study }\end{array}$ & $\begin{array}{l}\text { No. of } \\
\text { patients }\end{array}$ & Age, sex & $\begin{array}{l}\text { Anatomy } \\
\text { / Coex- } \\
\text { isting } \\
\text { lesions / } \\
\text { Symp- } \\
\text { toms / } \\
\text { Investi- } \\
\text { gations }\end{array}$ & Surgery & $\begin{array}{l}\text { Results/Foll } \\
\text { up }\end{array}$ \\
\hline 12. & $\begin{array}{l}\text { Shibuya K } \\
\text { et al, } \\
1996^{\mathrm{E} 51}\end{array}$ & 1974-1993 & 27 & $\begin{array}{l}1 \text { day-15 } \\
\text { years Female } \\
(18)\end{array}$ & $\begin{array}{l}\text { SV total } \\
(21), \text { partial } \\
(6), \text { dex- } \\
\text { tro/mesocardia } \\
70 \% \text { SVIVC } \\
(12), \\
\text { IVC-RA } \\
\text { junction } \\
(11), \text { low } \\
\text { RA }(4)\end{array}$ & $\begin{array}{l}\text { Surgery } \\
(18), \text { inter- } \\
\text { ventional } \\
\text { cath or both } \\
\text { No surgery } \\
\text { or interven- } \\
\text { tional cath } \\
(9)\end{array}$ & $\begin{array}{l}\text { Died (4) due } \\
\text { to severe } \\
\text { associated } \\
\text { anomalies }\end{array}$ \\
\hline 13. & $\begin{array}{l}\text { Idris MT et } \\
\text { al, } 1998^{\mathrm{E} 46}\end{array}$ & & 1 & $\begin{array}{l}27 \\
\text { year/Female }\end{array}$ & $\begin{array}{l}\text { CXR, TE - } \\
\text { dextrocar- } \\
\text { dia, dilated } \\
\text { right heart, } \\
\text { MVA } 1.9 \\
\mathrm{~cm}^{2}, \text { no } \\
\text { ASD Cath } \\
\text { Qp:Qs } 2.5: 1, \\
\text { PAP 30/15 } \\
\text { mmHg, } \\
\text { SVIVC }\end{array}$ & $\begin{array}{l}\text { Hypoplastic } \\
\text { right lung, } \\
\text { SV to } \\
\text { infradi- } \\
\text { aphragmatic } \\
\text { IVC }\end{array}$ & $\begin{array}{l}\text { Discharged } \\
\text { home, } \\
\text { patent } \\
\text { surgical } \\
\text { anastomosis }\end{array}$ \\
\hline
\end{tabular}




\begin{tabular}{|c|c|c|c|c|c|c|c|}
\hline S.No. & $\begin{array}{l}\text { Authors, } \\
\text { years }\end{array}$ & $\begin{array}{l}\text { Period of } \\
\text { study }\end{array}$ & $\begin{array}{l}\text { No. of } \\
\text { patients }\end{array}$ & Age, sex & $\begin{array}{l}\text { Anatomy } \\
\text { / Coex- } \\
\text { isting } \\
\text { lesions / } \\
\text { Symp- } \\
\text { toms / } \\
\text { Investi- } \\
\text { gations }\end{array}$ & Surgery & $\begin{array}{l}\text { Results/Foll } \\
\text { up }\end{array}$ \\
\hline 14. & $\begin{array}{l}\text { Vida VL et } \\
\text { al } 2018^{5}\end{array}$ & & 485 & $\begin{array}{l}\text { year }(282) \\
1-10(113) \\
>10 \text { year } \\
(90) \text { Female } \\
(305)\end{array}$ & $\begin{array}{l}51 \\
\text { institutions, } \\
\text { dextrocardia } \\
(240), \\
\text { mesocardia } \\
(83), \text { CHD } \\
(299), \text { ASD } \\
(243), \text { right } \\
\text { pulmonary } \\
\text { hypoplasia } \\
\text { (346), severe } \\
\text { PPH (46), } \\
\text { cardiac } \\
\text { symptoms } \\
\text { (227), } \\
\text { respiratory } \\
\text { (243) Qp:Qs } \\
2.1: 1 \text { SAS to } \\
\text { (R) lung } \\
\text { (248), coil } \\
\text { embolization } \\
\text { SAS (177), }\end{array}$ & $\begin{array}{l}\text { Not } \\
\text { mentioned }\end{array}$ & $\begin{array}{l}\text { Time to last } \\
\text { follow-up- } \\
\text { years } 7.2 \\
(2.2-14), \\
\text { STP HD } 17 \\
(6.1 \%) \text { STP } \\
\text { LD 11 } \\
\text { (39.\%) CMP } \\
\text { mortality } 13 \\
(6.3 \%) \text { Late } \\
\text { death } 5 \\
(12 \%) \\
\text { Symptoms } \\
\text { at follow-up } \\
172 / 451 \\
(37 \%) \text { Post- } \\
\text { operative } \\
\text { stenosis / } \\
\text { occlusion SV } \\
63 / 254 \\
(25 \%)- \\
\text { Reoperation } \\
42(67 \%), \\
\text { Untreated } \\
21(33 \%)\end{array}$ \\
\hline 15. & $\begin{array}{l}\text { Pfammatter } \\
\text { JP et al } \\
1997^{\mathrm{E} 40}\end{array}$ & 1997 & 1 & $\begin{array}{l}40 \text { weeks } \\
\text { gestation }\end{array}$ & $\begin{array}{l}\text { Dexocardia, } \\
\text { single S2, } \\
\text { Grade } 2 / 6 \\
\text { murmur, } \\
\text { Cath at } 6 \\
\text { weeks- left } \\
\text { sided } \\
\text { PVLA, } \\
\text { right sided } \\
\text { SV IVCm, } \\
\text { PAP } \\
67 / 19, \\
\text { PVR } 4 \\
\text { woods } \\
\text { unit/m², } \\
\text { ASD, } \\
\text { PDA, } \\
\text { MAPCAs }\end{array}$ & $\begin{array}{l}\text { Not } \\
\text { mentioned }\end{array}$ & $\begin{array}{l}\text { Coil } \\
\text { occlusion: } \\
\text { MAPCAs } \\
\text { done on } \\
\text { follow-up } \\
\text { (19 } \\
\text { months) } \\
\text { doing well }\end{array}$ \\
\hline
\end{tabular}




\begin{tabular}{|c|c|c|c|c|c|c|c|}
\hline S.No. & $\begin{array}{l}\text { Authors, } \\
\text { years }\end{array}$ & $\begin{array}{l}\text { Period of } \\
\text { study }\end{array}$ & $\begin{array}{l}\text { No. of } \\
\text { patients }\end{array}$ & Age, sex & $\begin{array}{l}\text { Anatomy } \\
\text { / Coex- } \\
\text { isting } \\
\text { lesions / } \\
\text { Symp- } \\
\text { toms / } \\
\text { Investi- } \\
\text { gations }\end{array}$ & Surgery & $\begin{array}{l}\text { Results/Foll } \\
\text { up }\end{array}$ \\
\hline 16. & $\begin{array}{l}\text { Schramel } \\
\text { FM et al, } \\
1995^{\mathrm{E} 17}\end{array}$ & 1967-1992 & 7 & $\begin{array}{l}4 \text { years, } 29 \\
\text { years, } 23 \\
\text { years, } 27 \\
\text { years, } 24 \\
\text { years, } 46 \\
\text { years, } 5 \\
\text { years }\end{array}$ & $\begin{array}{l}\text { SVIVC- CP } \\
\text { angle (5), } \\
\text { Hypoplasia- } \\
\text { bronchial } \\
\text { tree, } \\
\text { tracheal } \\
\text { bronchus SV } \\
\text { - ICV / LA } \\
(2)\end{array}$ & $\begin{array}{l}\text { Reimplantation } \\
\text { of the SV } \\
\text { into LA, } \\
\text { resection of } \\
\text { the } \\
\text { sequestered } \\
\text { lobe (2), } \\
\text { reimplanta- } \\
\text { tion of SV } \\
(1), \text { right } \\
\text { pneumonec- } \\
\text { tomy (1), } \\
\text { none (3) }\end{array}$ & $\begin{array}{l}\text { Postoperative } \\
\text { thrombosis / } \\
\text { fibrosis SV } \\
\text { needing } \\
\text { pneumonec- } \\
\text { tomy (2), } \\
\text { remaining } \\
\text { patients } \\
\text { uneventful } \\
\text { recovery }\end{array}$ \\
\hline 17. & $\begin{array}{l}\text { Salazer J } \\
1995^{\mathrm{E} 18}\end{array}$ & & 5 & $\begin{array}{l}\text { Female }(2) \\
\text { Age mean } \\
3.4 \text { years }(6 \\
\text { months-11 } \\
\text { years) }\end{array}$ & $\begin{array}{l}\text { SV Subdia } \\
\text { IVC (3), } \\
\text { peak } \\
\text { velocity } \\
0.6-1.0 \\
\text { m/sec, ASD } \\
(1) \\
\text { SVsupradia } \\
\text { IVC (2), } \\
\text { MAPCA } \\
\text { right lung } \\
(2)\end{array}$ & $\begin{array}{l}\text { Atrial septal } \\
\text { patch in } \\
\text { patient with } \\
\text { SV+ASD, } \\
\text { lobectomy } \\
\text { (1) without } \\
\text { chest inf } \\
\text { recurrent }\end{array}$ & $\begin{array}{l}\text { Not } \\
\text { mentioned }\end{array}$ \\
\hline
\end{tabular}




\begin{tabular}{|c|c|c|c|c|c|c|c|}
\hline S.No. & $\begin{array}{l}\text { Authors, } \\
\text { years }\end{array}$ & $\begin{array}{l}\text { Period of } \\
\text { study }\end{array}$ & $\begin{array}{l}\text { No. of } \\
\text { patients }\end{array}$ & Age, sex & $\begin{array}{l}\text { Anatomy } \\
\text { / Coex- } \\
\text { isting } \\
\text { lesions / } \\
\text { Symp- } \\
\text { toms / } \\
\text { Investi- } \\
\text { gations }\end{array}$ & Surgery & $\begin{array}{l}\text { Results/Foll } \\
\text { up }\end{array}$ \\
\hline 18. & $\begin{array}{l}\text { Morgan JR } \\
1971^{\text {E29 }}\end{array}$ & & & 22 years & $\begin{array}{l}\text { Respiratory } \\
\text { wheez } \\
\text { decrease } \\
\text { exercise } \\
\text { tolerance, } \\
\text { CXR destro- } \\
\text { cardia, } \\
\text { decreased } \\
\text { pulmonary } \\
\text { vascularity, } \\
\text { lung scan, } \\
\text { decrease } \\
\text { perfusion } \\
\text { right lung, } \\
\text { cath, PAP } \\
\text { 35 mmHg, } \\
\text { decreased } \\
\text { size RPA, } \\
\text { SV draining } \\
\text { to LA } \\
\text { scimitar sign } \\
\text { with normal } \\
\text { pulmonary } \\
\text { venous } \\
\text { drainage }\end{array}$ & $\begin{array}{l}\text { Not } \\
\text { mentioned }\end{array}$ & $\begin{array}{l}\text { Not } \\
\text { mentioned }\end{array}$ \\
\hline 19. & $\begin{array}{l}\text { Murphy, } \\
\text { Kerr and } \\
\text { Kirklin } \\
1971^{\text {E13 }}\end{array}$ & $1960-68$ & 6 & $\begin{array}{l}8,15,20,32, \\
57 \text { years } \\
\text { Female }(3)\end{array}$ & $\begin{array}{l}\text { scimitar } \\
\text { syndrome }\end{array}$ & $\begin{array}{l}\text { CPB, hy- } \\
\text { pothermia, } \\
\text { intra-atrial } \\
\text { tunnel, } \\
\text { tissue } \\
\text { tunnel, } \\
\text { pericardium, } \\
\text { Dacron } \\
\text { graft-used }\end{array}$ & $\begin{array}{l}\text { Hospital } \\
\text { death (12), } \\
\text { survived (5) } \\
\text { Follow-up - } \\
\text { not } \\
\text { mentioned }\end{array}$ \\
\hline 20. & $\begin{array}{l}\text { Mardini MK } \\
\text { et al, } 1982^{6}\end{array}$ & 1982 & 3 & $\begin{array}{l}8 \text { months, } 3 \\
\text { years, } 2.5 \\
\text { months } \\
\text { Male }(3)\end{array}$ & $\begin{array}{l}\text { Recurrent } \\
\text { RTI, } \\
\text { perfusion } \\
\text { scan - less } \\
\text { perfusion } \\
\text { (R) lung } \\
\text { compared to } \\
\text { left Qp:Qw } \\
\text { 1.5:1 }\end{array}$ & $\begin{array}{l}\text { Not } \\
\text { mentioned }\end{array}$ & $\begin{array}{l}\text { Not } \\
\text { mentioned }\end{array}$ \\
\hline
\end{tabular}




\begin{tabular}{|c|c|c|c|c|c|c|c|}
\hline S.No. & $\begin{array}{l}\text { Authors, } \\
\text { years }\end{array}$ & $\begin{array}{l}\text { Period of } \\
\text { study }\end{array}$ & $\begin{array}{l}\text { No. of } \\
\text { patients }\end{array}$ & Age, sex & $\begin{array}{l}\text { Anatomy } \\
\text { / Coex- } \\
\text { isting } \\
\text { lesions / } \\
\text { Symp- } \\
\text { toms / } \\
\text { Investi- } \\
\text { gations }\end{array}$ & Surgery & $\begin{array}{l}\text { Results/Foll } \\
\text { up }\end{array}$ \\
\hline 21. & $\begin{array}{l}\text { Mathey J et } \\
\text { al, } 1968^{8}\end{array}$ & 1968 & 3 & $\begin{array}{l}9 \text { years }(\mathrm{F}), \\
7 \text { years }(\mathrm{F}), \\
15 \text { years }(\mathrm{M})\end{array}$ & $\begin{array}{l}\text { Recurrent } \\
\text { RTI, } \\
\text { murmur- } \\
\text { ESM-PA } \\
\text { cath, CXR- } \\
\text { scimitar sign } \\
\text { cath } \\
\text { confirmed } \\
\text { the } \\
\text { diagnosis }\end{array}$ & $\begin{array}{l}\text { Sternotomy } \\
(1), \text { right } \\
\text { thoracotomy } \\
(2), \text { SVRA } \\
(1) \text {, division } \\
+ \text { transloca- } \\
\text { tion SVLA } \\
(1) \text {, division } \\
+ \text { transloca- } \\
\text { tion SVgraft } \\
20 \text { mm - LA } \\
(1)\end{array}$ & $\begin{array}{l}\text { Postoperative- } \\
\text { uneventful }\end{array}$ \\
\hline 22 & $\begin{array}{l}\text { Lloyd IE et } \\
\text { al, } 2014^{\text {E35 }}\end{array}$ & 2014 & 2 & $\begin{array}{l}7 \text { months } \\
(\mathrm{F}), 2 \text { weeks } \\
(\mathrm{M})\end{array}$ & $\begin{array}{l}\text { Case 1: SS, } \\
\text { SVIVC, } \\
\text { additional } \\
\text { ASD, cleft, } \\
\text { ATL, retroe- } \\
\text { sophageal, } \\
\text { hypoplastic } \\
\text { RPA, } \\
\text { LSVCCS, } \\
\text { hypoplastic } \\
\text { right lung } \\
\text { Case } 2: \text { SS, } \\
\text { SVIVC, } \\
\text { associated } \\
\text { TGA, VSD, } \\
\text { PDA } \\
\text { Skeletal- } \\
\text { proximal rib } \\
\text { fusion } 7^{\text {th }} \text {, } \\
8^{\text {th }}, \text { subnu- } \\
\text { merary ribs, } \\
\text { 10, 11 } \\
\text { Hemiverte- } \\
\text { brae T8-T9 } \\
\text { Micromelia- } \\
\text { upper } \\
\text { extremities }\end{array}$ & $\begin{array}{l}\text { Necropsy } \\
\text { study }\end{array}$ & $\begin{array}{l}\text { Not } \\
\text { mentioned }\end{array}$ \\
\hline
\end{tabular}




\begin{tabular}{|c|c|c|c|c|c|c|c|}
\hline S.No. & $\begin{array}{l}\text { Authors, } \\
\text { years }\end{array}$ & $\begin{array}{l}\text { Period of } \\
\text { study }\end{array}$ & $\begin{array}{l}\text { No. of } \\
\text { patients }\end{array}$ & Age, sex & $\begin{array}{l}\text { Anatomy } \\
\text { / Coex- } \\
\text { isting } \\
\text { lesions / } \\
\text { Symp- } \\
\text { toms / } \\
\text { Investi- } \\
\text { gations }\end{array}$ & Surgery & $\begin{array}{l}\text { Results/Foll } \\
\text { up }\end{array}$ \\
\hline 23. & $\begin{array}{l}\text { Mas C et al } \\
2000^{\mathrm{E} 47}\end{array}$ & 2000 & 1 & 3 years & $\begin{array}{l}\text { Asymptomatic } \\
\text { Loud S2 } \\
\text { (A2), CXR- } \\
\text { mesocardia, } \\
\text { hypoplastic } \\
\text { right lung } \\
\text { Echo, } \\
\text { Angio- } \\
\text { abnormal } \\
\text { venous flow } \\
\text { right side } \\
\text { IVC-RA } \\
\text { junction } \\
\text { Right } \\
\text { lungSV } \\
\text { which } \\
\text { formed an } \\
\text { arch } \\
\text { draining to } \\
\text { IVC/RA } \\
\text { SV-IVC } \\
\text { junction } \\
\text { 5mm, } \\
\text { SV-10mm at } \\
\text { hilum }\end{array}$ & $\begin{array}{l}\text { Coil em- } \\
\text { bolization: } \\
\text { IVC-SV } \\
\text { junction }\end{array}$ & $\begin{array}{l}\text { Follow-up at } \\
5 \text { months } \\
\text { Complete } \\
\text { occlusion } \\
\text { lower end } \\
\text { SV }\end{array}$ \\
\hline 24. & $\begin{array}{l}\text { McBride ME } \\
\text { et al, } 2009^{10}\end{array}$ & 2009 & 1 & $\begin{array}{l}\text { New born } \\
\text { female }\end{array}$ & $\begin{array}{l}\text { SS with } \\
\text { HLHS (MS, } \\
\text { aortic } \\
\text { atresia } \\
\text { variant) } \\
\text { Cath } \\
\text { hypoplastic } \\
\text { right lung, } \\
\text { SS }\end{array}$ & $\begin{array}{l}\text { Successful } \\
\text { norwood } \\
\text { operation } \\
\text { with Sano } \\
\text { modifica- } \\
\text { tion, } \\
\text { returned at } \\
\text { age of } 5 \\
\text { months } \\
\text { successful } \\
\text { Glenn }\end{array}$ & $\begin{array}{l}\text { At the time } \\
\text { of reporting } \\
\text { - surviving }\end{array}$ \\
\hline
\end{tabular}




\begin{tabular}{|c|c|c|c|c|c|c|c|}
\hline S.No. & $\begin{array}{l}\text { Authors, } \\
\text { years }\end{array}$ & $\begin{array}{l}\text { Period of } \\
\text { study }\end{array}$ & $\begin{array}{l}\text { No. of } \\
\text { patients }\end{array}$ & Age, sex & $\begin{array}{l}\text { Anatomy } \\
\text { / Coex- } \\
\text { isting } \\
\text { lesions / } \\
\text { Symp- } \\
\text { toms / } \\
\text { Investi- } \\
\text { gations }\end{array}$ & Surgery & $\begin{array}{l}\text { Results/Foll } \\
\text { up }\end{array}$ \\
\hline 25. & $\begin{array}{l}\text { Lam TT et } \\
\text { al } 2006^{\mathrm{E} 9}\end{array}$ & 2006 & 2 & $\begin{array}{l}4 \text { years, } 14 \\
\text { years }\end{array}$ & $\begin{array}{l}\text { Cath SS, } \\
\text { secundum } \\
\text { ASD, Qp:Qs } \\
2.6: 1\end{array}$ & $\begin{array}{l}\text { CPB, } \\
\text { bicaval } \\
\text { cannulation, } \\
\text { cannulation, } \\
\text { cardioplegic } \\
\text { arrest, } \\
\text { SV-IVC } \\
\text { junction } \\
\text { divided } 12 \\
\text { mm, 16mm } \\
\text { PTFE graft } \\
\text { interposed } \\
\text { between the } \\
\text { divided SV } \\
\text { to LA ASD } \\
\text { closed with } \\
\text { pericardial } \\
\text { patch }\end{array}$ & $\begin{array}{l}\text { Echo at } 4 \\
\text { months, } 6 \\
\text { months - } \\
\text { unob- } \\
\text { structed } \\
\text { laminar flow } \\
\text { from SV to } \\
\text { LA }\end{array}$ \\
\hline 26. & $\begin{array}{l}\text { Eckhauser } \\
\text { AW et al, } \\
2013^{\text {E19 }}\end{array}$ & 2013 & 5 & $\begin{array}{l}1 \text { day male, } \\
5 \text { year } \\
\text { female, } 1 \\
\text { day female, } \\
1 \text { day } \\
\text { female, } 1 \\
\text { day male }\end{array}$ & $\begin{array}{l}\text { Case 1: SS, } \\
\text { HLHS, } \\
\text { DORV, } \\
\text { bilateral } \\
\text { SVC, severe } \\
\text { PA } \\
\text { hypoplasia } \\
\text { (Z-6.5), } \\
\text { MAPCA } \\
\text { (large) - } \\
\text { right lung } \\
\text { Norwood } \\
\text { with a 5mm } \\
\text { Sano shunt } \\
\text { (SV, APC } \\
\text { left unad- } \\
\text { dressed) At } \\
11 \text { months } \\
\text { bilateral } \\
\text { SCPC } \\
\text { attempted- } \\
\text { abandoned } \\
\text { because } \\
\text { hypoplastic } \\
\text { RPC }\end{array}$ & $\begin{array}{l}\text { Case 1: SS, } \\
\text { HLHS, } \\
\text { DORV, } \\
\text { bilateral } \\
\text { SVC, severe } \\
\text { PA } \\
\text { hypoplasia } \\
\text { (Z-6.5), } \\
\text { MAPCA } \\
\text { (large) - } \\
\text { right lung } \\
\text { Norwood } \\
\text { with a 5mm } \\
\text { Sano shunt } \\
\text { (SV, APC } \\
\text { left unad- } \\
\text { dressed) At } \\
\text { 11 months } \\
\text { bilateral } \\
\text { SCPC } \\
\text { attempted- } \\
\text { abandoned } \\
\text { because } \\
\text { hypoplastic } \\
\text { RPC }\end{array}$ & $\begin{array}{l}\text { Tracheostomy } \\
\text { Home- died } \\
\text { age } 3 \text { years } \\
\text { (respiratory } \\
\text { infection) }\end{array}$ \\
\hline
\end{tabular}




\begin{tabular}{|c|c|c|c|c|c|c|c|}
\hline S.No. & $\begin{array}{l}\text { Authors, } \\
\text { years }\end{array}$ & $\begin{array}{l}\text { Period of } \\
\text { study }\end{array}$ & $\begin{array}{l}\text { No. of } \\
\text { patients }\end{array}$ & Age, sex & $\begin{array}{l}\text { Anatomy } \\
\text { / Coex- } \\
\text { isting } \\
\text { lesions / } \\
\text { Symp- } \\
\text { toms / } \\
\text { Investi- } \\
\text { gations }\end{array}$ & Surgery & $\begin{array}{l}\text { Results/Foll } \\
\text { up }\end{array}$ \\
\hline & & & & & $\begin{array}{l}\text { Case 2: SS, } \\
\text { HLHS, } \\
\text { norwood } \\
\text { with a } 5 \mathrm{~mm} \\
\text { Sano, } \\
\text { ligation } \\
\text { APC, SV } \\
\text { intact, at } 10 \\
\text { years of age- } \\
\text { right hemi } \\
\text { Fontan, left } \\
\text { BDG, } \\
\text { stenting, } \\
\text { proximal } \\
\text { RPA, PVR } \\
3.7 / \text { wu/m² } \\
\text { Age } 18 \\
\text { years, } \\
\text { extracardiac } \\
\text { TCPC }\end{array}$ & $\begin{array}{l}\text { Case 2: SS, } \\
\text { HLHS, } \\
\text { norwood } \\
\text { with a } 5 \mathrm{~mm} \\
\text { Sano, } \\
\text { ligation } \\
\text { APC, SV } \\
\text { intact, at } 10 \\
\text { years of age- } \\
\text { right hemi } \\
\text { Fontan, left } \\
\text { BDG, } \\
\text { stenting, } \\
\text { proximal } \\
\text { RPA, PVR } \\
3.7 / \text { wu/m² } \\
\text { Age } 18 \\
\text { years, } \\
\text { extracardiac } \\
\text { TCPC }\end{array}$ & $\begin{array}{l}\text { Doing well } \\
\text { saturation } \\
>90 \%\end{array}$ \\
\hline
\end{tabular}




\begin{tabular}{|c|c|c|c|c|c|c|c|}
\hline S.No. & $\begin{array}{l}\text { Authors, } \\
\text { years }\end{array}$ & $\begin{array}{l}\text { Period of } \\
\text { study }\end{array}$ & $\begin{array}{l}\text { No. of } \\
\text { patients }\end{array}$ & Age, sex & $\begin{array}{l}\text { Anatomy } \\
\text { / Coex- } \\
\text { isting } \\
\text { lesions / } \\
\text { Symp- } \\
\text { toms / } \\
\text { Investi- } \\
\text { gations }\end{array}$ & Surgery & $\begin{array}{l}\text { Results/Foll } \\
\text { up }\end{array}$ \\
\hline & & & & & $\begin{array}{l}\text { Case 3: SS, } \\
\text { HLHS, } \\
\text { severe RPA } \\
\text { hypoplasia } \\
(3.3 \mathrm{~mm}, \\
\text { Z-2.2), cath } \\
\text { obstruction } \\
\text { SV (entire } \\
\text { right lung) } \\
\text { hybrid } \\
\text { procedure, } \\
\text { bilateral PA } \\
\text { band, ductal } \\
\text { stent severe } \\
\text { CHF Age } 5 \\
\text { months- } \\
\text { biatrial } \\
\text { heart trans- } \\
\text { plantation, } \\
\text { atrial } \\
\text { septum left } \\
\text { intact with } \\
\text { SVRA } \\
\text { ECMO- } \\
\text { tracheostomy }\end{array}$ & $\begin{array}{l}\text { Case 3: SS, } \\
\text { HLHS, } \\
\text { severe RPA } \\
\text { hypoplasia } \\
(3.3 \text { mm, } \\
\text { Z-2.2), cath } \\
\text { obstruction } \\
\text { SV (entire } \\
\text { right lung) } \\
\text { hybrid } \\
\text { procedure, } \\
\text { bilateral PA } \\
\text { band, ductal } \\
\text { stent severe } \\
\text { CHF Age } 5 \\
\text { months- } \\
\text { biatrial } \\
\text { heart trans- } \\
\text { plantation, } \\
\text { atrial } \\
\text { septum left } \\
\text { intact with } \\
\text { SVRA } \\
\text { ECMO- } \\
\text { tracheostomy }\end{array}$ & $\begin{array}{l}\text { Follow-up } 6 \\
\text { years, doing } \\
\text { well }\end{array}$ \\
\hline
\end{tabular}




\begin{tabular}{|c|c|c|c|c|c|c|c|}
\hline S.No. & $\begin{array}{l}\text { Authors, } \\
\text { years }\end{array}$ & $\begin{array}{l}\text { Period of } \\
\text { study }\end{array}$ & $\begin{array}{l}\text { No. of } \\
\text { patients }\end{array}$ & Age, sex & $\begin{array}{l}\text { Anatomy } \\
\text { / Coex- } \\
\text { isting } \\
\text { lesions / } \\
\text { Symp- } \\
\text { toms / } \\
\text { Investi- } \\
\text { gations }\end{array}$ & Surgery & $\begin{array}{l}\text { Results/Foll } \\
\text { up }\end{array}$ \\
\hline & & & & & $\begin{array}{l}\text { Case 4: SS, } \\
\text { HLHS, dex- } \\
\text { trocardia, } \\
\text { bilateral } \\
\text { SVC, SV } \\
\text { RA, severe } \\
\text { RPA } \\
\text { hypoplasia, } \\
\text { right } \\
\text { pulmonary } \\
\text { sequestra- } \\
\text { tion Hybrid } \\
\text { procedure- } \\
\text { bilateral PA } \\
\text { band, } \\
\text { inter-atrial } \\
\text { stent Age: } 5 \\
\text { months- } \\
\text { bicaval } \\
\text { cardiac } \\
\text { transplanta- } \\
\text { tion, } \\
\text { reimplanta- } \\
\text { tion } \\
\text { SVLA }\end{array}$ & $\begin{array}{l}\text { Case 4: SS, } \\
\text { HLHS, dex- } \\
\text { trocardia, } \\
\text { bilateral } \\
\text { SVC, SV } \\
\text { RA, severe } \\
\text { RPA } \\
\text { hypoplasia, } \\
\text { right } \\
\text { pulmonary } \\
\text { sequestra- } \\
\text { tion Hybrid } \\
\text { procedure- } \\
\text { bilateral PA } \\
\text { band, } \\
\text { inter-atrial } \\
\text { stent Age: } 5 \\
\text { months- } \\
\text { bicaval } \\
\text { cardiac } \\
\text { transplanta- } \\
\text { tion, } \\
\text { reimplanta- } \\
\text { tion } \\
\text { SVLA }\end{array}$ & $\begin{array}{l}\text { Discharge } \\
\text { home with } \\
\text { tracheostomy }\end{array}$ \\
\hline
\end{tabular}




\begin{tabular}{|c|c|c|c|c|c|c|c|}
\hline S.No. & $\begin{array}{l}\text { Authors, } \\
\text { years }\end{array}$ & $\begin{array}{l}\text { Period of } \\
\text { study }\end{array}$ & $\begin{array}{l}\text { No. of } \\
\text { patients }\end{array}$ & Age, sex & $\begin{array}{l}\text { Anatomy } \\
\text { / Coex- } \\
\text { isting } \\
\text { lesions / } \\
\text { Symp- } \\
\text { toms / } \\
\text { Investi- } \\
\text { gations }\end{array}$ & Surgery & $\begin{array}{l}\text { Results/Foll } \\
\text { up }\end{array}$ \\
\hline & & & & & $\begin{array}{l}\text { Case 5: SS, } \\
\text { HLHS, right } \\
\text { lung } \\
\text { hypoplasia, } \\
\text { LSVCCS, } \\
\text { Norwood } \\
\text { with a } \\
\text { 3.5mm } \\
\text { RMBT, SV- } \\
\text { cavo atrial } \\
\text { junction, } \\
\text { mild RPA } \\
\text { hypoplasia, } \\
\text { moderate } \\
\text { sized APC } \\
\text { Age } 5 \\
\text { months- } \\
\text { unsuitable } \\
\text { for } 2^{\text {nd }} \text { stage } \\
\text { palliation } \\
\text { with an } \\
\text { elevated } \\
\text { PVR Age } 8 \\
\text { months- } \\
\text { stenting } \\
\text { proximal BT } \\
\text { shunt, } \\
\text { balloon } \\
\text { angioplasty } \\
\text { instent SV }\end{array}$ & $\begin{array}{l}\text { Case 5: SS, } \\
\text { HLHS, right } \\
\text { lung } \\
\text { hypoplasia, } \\
\text { LSVCCS, } \\
\text { Norwood } \\
\text { with a } \\
\text { 3.5mm } \\
\text { RMBT, SV- } \\
\text { cavo atrial } \\
\text { junction, } \\
\text { mild RPA } \\
\text { hypoplasia, } \\
\text { moderate } \\
\text { sized APC } \\
\text { Age } 5 \\
\text { months- } \\
\text { unsuitable } \\
\text { for } 2^{\text {nd }} \text { stage } \\
\text { palliation } \\
\text { with an } \\
\text { elevated } \\
\text { PVR Age } 8 \\
\text { months- } \\
\text { stenting } \\
\text { proximal BT } \\
\text { shunt, } \\
\text { balloon } \\
\text { angioplasty } \\
\text { instent SV }\end{array}$ & Survived \\
\hline
\end{tabular}




\begin{tabular}{|c|c|c|c|c|c|c|c|}
\hline S.No. & $\begin{array}{l}\text { Authors, } \\
\text { years }\end{array}$ & $\begin{array}{l}\text { Period of } \\
\text { study }\end{array}$ & $\begin{array}{l}\text { No. of } \\
\text { patients }\end{array}$ & Age, sex & $\begin{array}{l}\text { Anatomy } \\
\text { / Coex- } \\
\text { isting } \\
\text { lesions / } \\
\text { Symp- } \\
\text { toms / } \\
\text { Investi- } \\
\text { gations }\end{array}$ & Surgery & $\begin{array}{l}\text { Results/Foll } \\
\text { up }\end{array}$ \\
\hline 27. & $\begin{array}{l}\text { Farnsworth } \\
\text { AE et al, } \\
1974^{\mathrm{E} 34}\end{array}$ & 1974 & 2 & 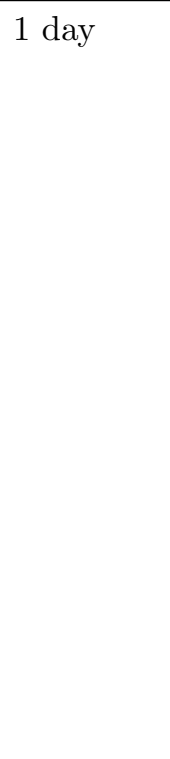 & $\begin{array}{l}\text { SS, right } \\
\text { lung } \\
\text { markedly } \\
\text { hypoplas- } \\
\text { tic, } \\
\text { dextro- } \\
\text { posed } \\
\text { heart, } \\
\text { MAPCA } \\
\text { pierced } \\
\text { the di- } \\
\text { aphragm, } \\
\text { PFO } \\
\text { (8mm), } \\
\text { VSD } \\
\text { (18mm), } \\
\text { RV wall } \\
\text { hypertrophied }\end{array}$ & $\begin{array}{l}\text { SS, right } \\
\text { lung } \\
\text { markedly } \\
\text { hypoplas- } \\
\text { tic, } \\
\text { dextro- } \\
\text { posed } \\
\text { heart, } \\
\text { MAPCA } \\
\text { pierced } \\
\text { the di- } \\
\text { aphragm, } \\
\text { PFO } \\
\text { (8mm), } \\
\text { VSD } \\
\text { (18mm), } \\
\text { RV wall } \\
\text { hypertrophied }\end{array}$ & $\begin{array}{l}\text { Necropsy } \\
\text { study }\end{array}$ \\
\hline & & & & 45 years & $\begin{array}{l}\text { SV subdi- } \\
\text { aphragmatic } \\
\text { IVC, Qp:Qs } \\
\text { 2.7:1 Right } \\
\text { bronchogram- } \\
\text { middle lobe } \\
\text { from upper } \\
\text { lobe RALT- } \\
\text { SV to LA } \\
\text { anastomosed } \\
\text { through RA } \\
\text { under CPB }\end{array}$ & $\begin{array}{l}\text { SV subdi- } \\
\text { aphragmatic } \\
\text { IVC, Qp:Qs } \\
\text { 2.7:1 Right } \\
\text { bronchogram- } \\
\text { middle lobe } \\
\text { from upper } \\
\text { lobe RALT- } \\
\text { SV to LA } \\
\text { anastomosed } \\
\text { through RA } \\
\text { under CPB }\end{array}$ & $\begin{array}{l}\text { Survived at } \\
\text { the time of } \\
\text { reporting }\end{array}$ \\
\hline
\end{tabular}




\begin{tabular}{|c|c|c|c|c|c|c|c|}
\hline S.No. & $\begin{array}{l}\text { Authors, } \\
\text { years }\end{array}$ & $\begin{array}{l}\text { Period of } \\
\text { study }\end{array}$ & $\begin{array}{l}\text { No. of } \\
\text { patients }\end{array}$ & Age, sex & $\begin{array}{l}\text { Anatomy } \\
\text { / Coex- } \\
\text { isting } \\
\text { lesions / } \\
\text { Symp- } \\
\text { toms / } \\
\text { Investi- } \\
\text { gations }\end{array}$ & Surgery & $\begin{array}{l}\text { Results/Foll } \\
\text { up }\end{array}$ \\
\hline 28. & $\begin{array}{l}\text { Calhoun } \\
\text { RF and } \\
\text { Mee RBB, } \\
2003^{\mathrm{E} 11}\end{array}$ & 2003 & 2 & $\begin{array}{l}\text { Not } \\
\text { mentioned }\end{array}$ & $\begin{array}{l}\text { Infantile } \\
\text { SS with } \\
\text { short } \\
\text { lung- } \\
\text { enveloped } \\
\text { scimitar } \\
\text { veins, } \\
\text { portioning } \\
\text { of the } \\
\text { inferior } \\
\text { cavoatrial } \\
\text { junction } \\
\text { using a } \\
\text { pericardial } \\
\text { patch with } \\
\text { the SV } \\
\text { draining } \\
\text { into the } \\
\text { posterior } \\
\text { compart- } \\
\text { ment } \\
\text { which was } \\
\text { anasto- } \\
\text { mosed to } \\
\text { the LA }\end{array}$ & $\begin{array}{l}\text { Infantile } \\
\text { SS with } \\
\text { short } \\
\text { lung- } \\
\text { enveloped } \\
\text { scimitar } \\
\text { veins, } \\
\text { portioning } \\
\text { of the } \\
\text { inferior } \\
\text { cavoatrial } \\
\text { junction } \\
\text { using a } \\
\text { pericardial } \\
\text { patch with } \\
\text { the SV } \\
\text { draining } \\
\text { into the } \\
\text { posterior } \\
\text { compart- } \\
\text { ment } \\
\text { which was } \\
\text { anasto- } \\
\text { mosed to } \\
\text { the LA }\end{array}$ & $\begin{array}{l}1 \text { patient } \\
\text { recovered } \\
\text { fully from } \\
\mathrm{CHF}, 2^{\text {nd }} \\
\text { patient } \\
\text { underwent } \\
\text { heart lung } \\
\text { transplantatio }\end{array}$ \\
\hline 29. & $\begin{array}{l}\text { Brown JW } \\
\text { et al, } 2003^{\mathrm{E} 7}\end{array}$ & $1990-2000$ & 9 & $\begin{array}{l}\text { Age at pre- } \\
\text { sentation: } 7 \\
\text { months- } 43 \\
\text { years (Mean, } \\
11.5 \pm 17.6 \\
\text { years), } \\
\text { Female (8) }\end{array}$ & $\begin{array}{l}\text { Recurrent } \\
\text { pneumonia, } \\
\text { SS, SV } \\
\text { infradi- } \\
\text { aphragmatic } \\
\text { IVC, extra } \\
\text { lobar seques- } \\
\text { tration (3), } \\
\text { Qp:Qs } \\
\text { 1.6-3.1:1.0, } \\
\text { no ASD }\end{array}$ & $\begin{array}{l}\mathrm{SV} \text { to LA } \\
\text { anastomosis } \\
\text { without } \\
\mathrm{CPB} \text { via } \\
\text { right } \\
\text { anterolateral } \\
\text { thoracotomy }\end{array}$ & $\begin{array}{l}\text { HD, LD-Nil } \\
\text { Follow-up } \\
\text { mean } 55 \pm 46 \\
\text { months (a } \\
\text { patent } \\
\text { anastomosis } \\
\text { without any } \\
\text { evidence of } \\
\text { restenosis) }\end{array}$ \\
\hline
\end{tabular}




\begin{tabular}{|c|c|c|c|c|c|c|c|}
\hline S.No. & $\begin{array}{l}\text { Authors, } \\
\text { years }\end{array}$ & $\begin{array}{l}\text { Period of } \\
\text { study }\end{array}$ & $\begin{array}{l}\text { No. of } \\
\text { patients }\end{array}$ & Age, sex & $\begin{array}{l}\text { Anatomy } \\
\text { / Coex- } \\
\text { isting } \\
\text { lesions / } \\
\text { Symp- } \\
\text { toms / } \\
\text { Investi- } \\
\text { gations }\end{array}$ & Surgery & $\begin{array}{l}\text { Results/Foll } \\
\text { up }\end{array}$ \\
\hline 30. & $\begin{array}{l}\text { Dupuis C et } \\
\text { al, } 1992^{12}\end{array}$ & 1960-1990 & 122 & $\begin{array}{l}\text { Not } \\
\text { mentioned }\end{array}$ & $\begin{array}{l}22 \text { university } \\
\text { centers, } \\
\text { scimitar } \\
\text { syndrome, } \\
\text { average } \\
\text { follow-up } 22 \\
\text { years, } \\
\text { pneumonia } \\
\text { (38), slight } \\
\text { DOE (23), } \\
\text { retraction of } \\
\text { hemothorax } \\
(8), \\
\text { hemoptysis } \\
\text { (7), } \\
\text { dextrocardia } \\
(98), \\
\text { hypoplastic } \\
\text { lung (102), } \\
\text { ASD (16), } \\
\text { PDA (3), } \\
\text { SVC to CS } \\
(1), \text { azygos } \\
\text { continuation } \\
\text { IVC (1), cor- } \\
\text { triatriatum } \\
(1), \\
\text { vertebral } \\
\text { malforma- } \\
\text { tion (1), } \\
\text { scoliosis (1), } \\
\text { horseshoe } \\
\text { kidney (1), } \\
\text { leftright } \\
\text { shunt <50\% } \\
\text { (100/122 } \\
\text { years), } \\
\text { PAP-normal } \\
\text { (94), slightly } \\
\text { elevated (28) }\end{array}$ & $\begin{array}{l}22 \text { university } \\
\text { centers, } \\
\text { scimitar } \\
\text { syndrome, } \\
\text { average } \\
\text { follow-up } 22 \\
\text { years, } \\
\text { pneumonia } \\
\text { (38), slight } \\
\text { DOE (23), } \\
\text { retraction of } \\
\text { hemothorax } \\
(8), \\
\text { hemoptysis } \\
\text { (7), } \\
\text { dextrocardia } \\
(98), \\
\text { hypoplastic } \\
\text { lung (102), } \\
\text { ASD (16), } \\
\text { PDA (3), } \\
\text { SVC to CS } \\
(1), \text { azygos } \\
\text { continuation } \\
\text { IVC (1), cor- } \\
\text { triatriatum } \\
(1), \\
\text { vertebral } \\
\text { malforma- } \\
\text { tion (1), } \\
\text { scoliosis (1), } \\
\text { horseshoe } \\
\text { kidney (1), } \\
\text { leftright } \\
\text { shunt <50\% } \\
\text { (100/122 } \\
\text { years), } \\
\text { PAP-normal } \\
\text { (94), slightly } \\
\text { elevated (28) }\end{array}$ & $\begin{array}{l}\text { Follow-up } 1 \\
\text { year }(20), \\
1-10 \text { years } \\
(52),>10 \\
\text { years }(50) \\
\text { Surgery } \\
(12), \text { deaths } \\
(4), \text { without } \\
\text { surgery }(79), \\
\text { deaths }(0)\end{array}$ \\
\hline
\end{tabular}




\begin{tabular}{|c|c|c|c|c|c|c|c|}
\hline S.No. & $\begin{array}{l}\text { Authors, } \\
\text { years }\end{array}$ & $\begin{array}{l}\text { Period of } \\
\text { study }\end{array}$ & $\begin{array}{l}\text { No. of } \\
\text { patients }\end{array}$ & Age, sex & $\begin{array}{l}\text { Anatomy } \\
\text { / Coex- } \\
\text { isting } \\
\text { lesions / } \\
\text { Symp- } \\
\text { toms / } \\
\text { Investi- } \\
\text { gations }\end{array}$ & Surgery & $\begin{array}{l}\text { Results/Foll } \\
\text { up }\end{array}$ \\
\hline 31. & $\begin{array}{l}\text { Jimenez } \\
\text { M et al, } \\
1988^{\mathrm{E} 31}\end{array}$ & 1988 & 1 & $\begin{array}{l}6 \text { months } \\
\text { male }\end{array}$ & $\begin{array}{l}\text { Recurrent } \\
\text { RTI, } \\
\text { CXR- hy- } \\
\text { poplastic } \\
\text { right lung, } \\
\text { dextroposition- } \\
\text { heart, } \\
\text { eventra- } \\
\text { tion } \\
\text { di- } \\
\text { aphragm, } \\
\text { sequestra- } \\
\text { tion right } \\
\text { lung lobe, } \\
\text { Doppler } \\
\text { echo-SV } \\
\text { (7mm } \\
\text { diameter) } \\
\text { diaphrag- } \\
\text { matic } \\
\text { portion } \\
\text { IVC, IVC } \\
\text { gradient } \\
\text { 8mmHg, } \\
\text { Cath- } \\
\text { IVC-RA } \\
\text { gradient } \\
\text { 9mmHg }\end{array}$ & $\begin{array}{l}\text { Medical } \\
\text { treatment }\end{array}$ & $\begin{array}{l}\text { Follow up } \\
6 \text { months, } \\
\text { asymptomatic }\end{array}$ \\
\hline
\end{tabular}




\begin{tabular}{|c|c|c|c|c|c|c|c|}
\hline S.No. & $\begin{array}{l}\text { Authors, } \\
\text { years }\end{array}$ & $\begin{array}{l}\text { Period of } \\
\text { study }\end{array}$ & $\begin{array}{l}\text { No. of } \\
\text { patients }\end{array}$ & Age, sex & $\begin{array}{l}\text { Anatomy } \\
\text { / Coex- } \\
\text { isting } \\
\text { lesions / } \\
\text { Symp- } \\
\text { toms / } \\
\text { Investi- } \\
\text { gations }\end{array}$ & Surgery & $\begin{array}{l}\text { Results/Foll } \\
\text { up }\end{array}$ \\
\hline 32. & $\begin{array}{l}\text { Kamiyama } \\
\mathrm{M} \text { et } \mathrm{al}^{\mathrm{E} 34}\end{array}$ & & 1 & $\begin{array}{l}4 \text { months, } \\
\text { female }\end{array}$ & $\begin{array}{l}\text { Recurrent } \\
\text { attacks } \\
\text { bron- } \\
\text { chospasm, } \\
\text { strider, } \\
\text { CXR- lung } \\
\text { hypoplasia, } \\
\text { mediastinal } \\
\text { shift to the } \\
\text { right, } \\
\text { scimitar } \\
\text { shadow, } \\
\text { echo- absent } \\
\text { RPA, } \\
\text { dilated } \\
\text { MPA, LPA, } \\
\text { PDA Cath- } \\
\text { absent RPC, } \\
\text { SV IVC, } \\
\text { MAPCA } \\
\text { from } \\
\text { abdominal } \\
\text { aorta, VSD, } \\
\text { PDA, } \\
\text { suprasys- } \\
\text { temic PAP, } \\
8 \text { months } \\
\text { age }\end{array}$ & $\begin{array}{l}\text { VSD,ICR, } \\
\text { PDA ligated } \\
2 \text { months } \\
\text { postop- } \\
\text { Severe } \\
\text { bronchospasm- } \\
\text { ventilated } \\
\text { for } 3 \text { months } \\
\text { Right } \\
\text { thoracotomy- } \\
\text { congested, } \\
\text { unilobu- } \\
\text { lated, poorly } \\
\text { ventilated } \\
\text { lung (R) } \\
\text { pneumonec- } \\
\text { tomy } \\
\text { Extubated } 3 \\
\text { days later }\end{array}$ & $\begin{array}{l}\text { Follow-up } \\
\text { (11 years), } \\
\text { asymptomatic } \\
\end{array}$ \\
\hline
\end{tabular}




\begin{tabular}{|c|c|c|c|c|c|c|c|}
\hline S.No. & $\begin{array}{l}\text { Authors, } \\
\text { years }\end{array}$ & $\begin{array}{l}\text { Period of } \\
\text { study }\end{array}$ & $\begin{array}{l}\text { No. of } \\
\text { patients }\end{array}$ & Age, sex & $\begin{array}{l}\text { Anatomy } \\
\text { / Coex- } \\
\text { isting } \\
\text { lesions / } \\
\text { Symp- } \\
\text { toms / } \\
\text { Investi- } \\
\text { gations }\end{array}$ & Surgery & $\begin{array}{l}\text { Results/Foll } \\
\text { up }\end{array}$ \\
\hline 33. & $\begin{array}{l}\text { Huebesch P } \\
\text { et al, } \\
1989^{\mathrm{E} 52}\end{array}$ & 1989 & 1 & $\begin{array}{l}66 \text { years, } \\
\text { female }\end{array}$ & $\begin{array}{l}\text { SOB, } \\
\text { mastectomy } \\
\text { for breast } \\
\text { carcinoma- } \\
16 \text { years } \\
\text { ago, fixed } \\
\text { spitting S2, } \\
\text { sonography- } \\
\text { abdominal- } \\
\text { distended } \\
\text { IVC, } \\
\text { atypical } \\
\text { vessel } \\
\text { entering } \\
\text { below the } \\
\text { diaphragm } \\
\text { Cath-O2 } \\
\text { step up at } \\
\text { IVC, CT- } \\
\text { SV entering } \\
\text { subdi- } \\
\text { aphragmatic } \\
\text { IVC }\end{array}$ & $\begin{array}{l}\text { Refused } \\
\text { surgical } \\
\text { treatment }\end{array}$ & $\begin{array}{l}\text { Not } \\
\text { mentioned }\end{array}$ \\
\hline 34. & $\begin{array}{l}\text { Geggel RL } \\
\text { et al, } \\
1993^{\mathrm{E} 28}\end{array}$ & 1993 & 1 & $\begin{array}{l}1 \text { year, } \\
\text { female }\end{array}$ & $\begin{array}{l}\text { Asymptomati } \\
\text { CXR (R) } \\
\text { lung } \\
\text { hypoplasia, } \\
\text { mediastinal } \\
\text { shift to } \\
\text { right, } 2 \\
\text { curvilinear } \\
\text { densities in } \\
\text { the right } \\
\text { chest, } \\
\text { oxygen step } \\
\text { up at IV, } \\
\text { PAP- } \\
\text { normal, } \\
\text { Qp:Qs 1.7:1 } \\
\text { IVC-RA } \\
\text { junction SV } \\
\text { RA SVC-RA } \\
\text { junction }\end{array}$ & , No surgery & $\begin{array}{l}\text { Not } \\
\text { mentioned }\end{array}$ \\
\hline
\end{tabular}




\begin{tabular}{|c|c|c|c|c|c|c|c|}
\hline S.No. & $\begin{array}{l}\text { Authors, } \\
\text { years }\end{array}$ & $\begin{array}{l}\text { Period of } \\
\text { study }\end{array}$ & $\begin{array}{l}\text { No. of } \\
\text { patients }\end{array}$ & Age, sex & $\begin{array}{l}\text { Anatomy } \\
\text { / Coex- } \\
\text { isting } \\
\text { lesions / } \\
\text { Symp- } \\
\text { toms / } \\
\text { Investi- } \\
\text { gations }\end{array}$ & Surgery & $\begin{array}{l}\text { Results/Foll } \\
\text { up }\end{array}$ \\
\hline 35. & $\begin{array}{l}\text { Gikonyo DK } \\
\text { et al, } \\
1986^{\text {E30 }}\end{array}$ & 1986 & 4 & 1 female & $\begin{array}{l}\text { All symp- } \\
\text { tomatic at } \\
\text { birth, CHF, } \\
\text { cyanosis, } \\
\text { respiratory } \\
\text { distress } \\
\text { syndrome, } \\
\text { SV infradi- } \\
\text { aphragmatic } \\
\text { IVC, } \\
\text { MAPCA- } \\
\text { abdominal } \\
\text { aortic RML } \\
\text { (case 1) } \\
\text { VSD, } \\
\text { tubular, } \\
\text { hypoplasia } \\
\text { aortic arch, } \\
\text { PDA, single } \\
\text { umbilical } \\
\text { artery, TOF, } \\
\text { PDA (right- } \\
\text { sided), } \\
\text { aberrant } \\
\text { LSA }\end{array}$ & $\begin{array}{l}\text { Necropsy } \\
\text { finding }\end{array}$ & $\begin{array}{l}\text { Not } \\
\text { mentioned }\end{array}$ \\
\hline \multirow[t]{2}{*}{36.} & \multirow[t]{2}{*}{$\begin{array}{l}\text { Frank JL } \\
\text { et al, } \\
1986^{\mathrm{E} 41}\end{array}$} & \multirow[t]{2}{*}{1986} & \multirow[t]{2}{*}{6} & $\begin{array}{l}1 \text { day } \\
\text { female }\end{array}$ & $\begin{array}{l}\text { SS infradi- } \\
\text { aphrag- } \\
\text { matic } \\
\text { IVC, SS } \\
\text { with } \\
\text { horseshoe } \\
\text { lung, right } \\
\text { lung } \\
\text { hypoplasia }\end{array}$ & $\begin{array}{l}\text { Died on } \\
\text { operation } \\
\text { table }\end{array}$ & \\
\hline & & & & $\begin{array}{l}9 \text { months } \\
\text { female }\end{array}$ & $\begin{array}{l}\text { SS infradi- } \\
\text { aphrag- } \\
\text { matic } \\
\text { IVC, SS } \\
\text { with } \\
\text { horseshoe } \\
\text { lung, right } \\
\text { lung } \\
\text { hypoplasia }\end{array}$ & \multicolumn{2}{|c|}{$\begin{array}{l}\text { pneumonectomyto } \\
\text { follow-up }\end{array}$} \\
\hline
\end{tabular}




\begin{tabular}{|c|c|c|c|c|c|c|c|}
\hline \multirow[t]{5}{*}{ S.No. } & $\begin{array}{l}\text { Authors, } \\
\text { years }\end{array}$ & $\begin{array}{l}\text { Period of } \\
\text { study }\end{array}$ & $\begin{array}{l}\text { No. of } \\
\text { patients }\end{array}$ & $\begin{array}{l}\text { Age, sex } \\
10 \text { months } \\
\text { female }\end{array}$ & $\begin{array}{l}\text { Anatomy } \\
\text { / Coex- } \\
\text { isting } \\
\text { lesions / } \\
\text { Symp- } \\
\text { toms / } \\
\text { Investi- } \\
\text { gations }\end{array}$ & \multicolumn{2}{|r|}{$\begin{array}{l}\text { Results/Foll } \\
\text { up }\end{array}$} \\
\hline & & & & $\begin{array}{l}10 \text { months } \\
\text { female }\end{array}$ & $\begin{array}{l}\text { SS infradi- } \\
\text { aphrag- } \\
\text { matic } \\
\text { IVC, SS } \\
\text { with } \\
\text { horseshoe } \\
\text { lung, right } \\
\text { lung } \\
\text { hypoplasia }\end{array}$ & \multicolumn{2}{|c|}{$\begin{array}{l}\text { pneumonectomyfellow-up } \\
\text { advised - } \\
\text { Refused }\end{array}$} \\
\hline & & & & $\begin{array}{l}4 \text { months } \\
\text { female }\end{array}$ & $\begin{array}{l}\text { SS infradi- } \\
\text { aphrag- } \\
\text { matic } \\
\text { IVC, SS } \\
\text { with } \\
\text { horseshoe } \\
\text { lung, right } \\
\text { lung } \\
\text { hypoplasia }\end{array}$ & $\begin{array}{l}\text { Medical } \\
\text { follow-up }\end{array}$ & $\begin{array}{l}\text { Not } \\
\text { mentioned }\end{array}$ \\
\hline & & & & $\begin{array}{l}1 \text { day } \\
\text { female }\end{array}$ & $\begin{array}{l}\text { SS infradi- } \\
\text { aphrag- } \\
\text { matic } \\
\text { IVC, SS } \\
\text { with } \\
\text { horseshoe } \\
\text { lung, right } \\
\text { lung } \\
\text { hypoplasia }\end{array}$ & $\begin{array}{l}\text { Right } \\
\text { pneumone }\end{array}$ & $\begin{array}{l}\text { Stormy } \\
\text { typostoperative- } \\
\text { discharged } \\
\text { home on } \\
21 \text { month }\end{array}$ \\
\hline & & & & $\begin{array}{l}1 \text { month } \\
\text { female }\end{array}$ & $\begin{array}{l}\text { SS infradi- } \\
\text { aphrag- } \\
\text { matic } \\
\text { IVC, SS } \\
\text { with } \\
\text { horseshoe } \\
\text { lung, right } \\
\text { lung } \\
\text { hypoplasia }\end{array}$ & $\begin{array}{l}\text { Medical } \\
\text { follow-up }\end{array}$ & $\begin{array}{l}\text { Not } \\
\text { mentioned }\end{array}$ \\
\hline
\end{tabular}




\begin{tabular}{|c|c|c|c|c|c|c|c|}
\hline S.No. & $\begin{array}{l}\text { Authors, } \\
\text { years }\end{array}$ & $\begin{array}{l}\text { Period of } \\
\text { study }\end{array}$ & $\begin{array}{l}\text { No. of } \\
\text { patients }\end{array}$ & Age, sex & $\begin{array}{l}\text { Anatomy } \\
\text { / Coex- } \\
\text { isting } \\
\text { lesions / } \\
\text { Symp- } \\
\text { toms / } \\
\text { Investi- } \\
\text { gations }\end{array}$ & Surgery & $\begin{array}{l}\text { Results/Foll } \\
\text { up }\end{array}$ \\
\hline 37. & $\begin{array}{l}\text { Co-Vu JG } \\
2010^{\mathrm{E} 61}\end{array}$ & 2010 & 1 & 3 days & $\begin{array}{l}\text { Non- } \\
\text { dysmorphic, } \\
\text { CXR car- } \\
\text { diomegaly, } \\
\text { TTE/MRI- } \\
\text { HLHS } \\
\text { with SS, } \\
\text { hypoplas- } \\
\text { tic (right) } \\
\text { lung, 50\% } \\
\text { of normal } \\
\text { size, small } \\
\text { RPA, } \\
\text { single } \\
\text { APC, } \\
\text { right lower } \\
\text { lung }\end{array}$ & $\begin{array}{l}\text { Initial } \\
\text { Norwood } \\
\text { with } \\
\text { sanomodi- } \\
\text { fication, } \\
\text { vascular } \\
\text { plug to } \\
\text { MAPCA, } \\
6.5 \\
\text { months - } \\
\text { cardiac } \\
\text { transplan- } \\
\text { tation, } \\
\text { ECMO } \\
\text { support }\end{array}$ & $\begin{array}{l}\text { Not } \\
\text { mentioned }\end{array}$ \\
\hline
\end{tabular}




\begin{tabular}{|c|c|c|c|c|c|c|c|}
\hline S.No. & $\begin{array}{l}\text { Authors, } \\
\text { years }\end{array}$ & $\begin{array}{l}\text { Period of } \\
\text { study }\end{array}$ & $\begin{array}{l}\text { No. of } \\
\text { patients }\end{array}$ & Age, sex & $\begin{array}{l}\text { Anatomy } \\
\text { / Coex- } \\
\text { isting } \\
\text { lesions / } \\
\text { Symp- } \\
\text { toms / } \\
\text { Investi- } \\
\text { gations }\end{array}$ & Surgery & $\begin{array}{l}\text { Results/Foll } \\
\text { up }\end{array}$ \\
\hline 38. & $\begin{array}{l}\text { Dupuis C et } \\
\text { al, } 1993^{11}\end{array}$ & 1970-1987 & 25 & 15 female & $\begin{array}{l}12 \text { European } \\
\text { centers, age } \\
\text { at hospital } \\
\text { admission } \\
\text { because of } \\
\text { severe } \\
\text { symptoms, } \\
\text { M1 wk (8), } \\
\text { 1-8 weeks } \\
(12), 3,4,6 \\
\text { months (3), } \\
8 \text { months } \\
(2), \text { CHF } \\
(14), \text { RDS } \\
(8), \text { dextro- } \\
\text { version, } \\
\text { severely } \\
\text { hypoplastic } \\
\text { right lung } \\
(19), \text { SV } \\
\text { image (6), } \\
\text { vertebral } \\
\text { malforma- } \\
\text { tion (3), } \\
\text { cath - } \\
\text { systolic PAP } \\
\text { increased in } \\
\text { all patients } \\
60-120 \\
\text { mmHg, PFO } \\
(19), \text { ASD } \\
(6), \\
\text { hypoplastic } \\
\text { RPA (21), } \\
\text { right lung } \\
\text { total } \\
\text { drainage } \\
(20), \text { partial } \\
\text { drainage (5), } \\
\text { MAPCA to } \\
\text { right lung } \\
(23)\end{array}$ & $\begin{array}{l}\text { Medical } \\
\text { treatment } \\
\text { alone }(10), \\
\text { death }(7), \\
\text { survivors } \\
(3), \text { good } \\
\text { result (2) } \\
\text { Surgical } \\
\text { treatment } \\
(15), \text { death } \\
(9), \\
\text { survivors } \\
(6), \text { good } \\
\text { result (5), } \\
\text { respiratory } \\
\text { problem (1) }\end{array}$ & $\begin{array}{l}\text { As } \\
\text { mentioned }\end{array}$ \\
\hline
\end{tabular}




\begin{tabular}{|c|c|c|c|c|c|c|c|}
\hline S.No. & $\begin{array}{l}\text { Authors, } \\
\text { years }\end{array}$ & $\begin{array}{l}\text { Period of } \\
\text { study }\end{array}$ & $\begin{array}{l}\text { No. of } \\
\text { patients }\end{array}$ & Age, sex & $\begin{array}{l}\text { Anatomy } \\
\text { / Coex- } \\
\text { isting } \\
\text { lesions / } \\
\text { Symp- } \\
\text { toms / } \\
\text { Investi- } \\
\text { gations }\end{array}$ & Surgery & $\begin{array}{l}\text { Results/Foll } \\
\text { up }\end{array}$ \\
\hline 39. & $\begin{array}{l}\text { Vida VL et } \\
\text { al, } 2013^{4}\end{array}$ & 2013 & 44 & $\begin{array}{l}25 \text { female, } \\
\text { median } 3 \\
\text { months }\end{array}$ & $\begin{array}{l}9 \text { Italian } \\
\text { centers } \\
\text { Isolated } \\
\text { infantile } \\
\text { CHD } \\
\text { infantile } 33 \\
\text { (75\%) 11 } \\
\text { (25\%) Age } \\
\text { at diagnosis } \\
\text { (m) 1.7 } \\
\text { (0-41) 0.3 } \\
\text { (0.1-30) } \\
\text { Asymp- } \\
\text { tomatic } 184 \\
\text { CHF } 24 \\
\text { Respiratory } \\
\text { symptoms } \\
155 \text { Qp:Qs } \\
\text { 1.45 (1-3) } \\
\text { 1.95 (1-2.8) } \\
\text { mPAP } \\
\text { (mmHg) 20 } \\
\text { (13-34) } 34 \\
\text { (18-50) Coil- } \\
\text { MAPCA } 11 \\
4 \text { Pulmonary } \\
\text { hypoplasia } \\
178 \text { Surgery } \\
\text { for other } \\
\text { CHD } 08 \\
\text { Deaths } 02 \\
\text { Respiratory } \\
\text { symptoms } 2 \\
1\end{array}$ & $\begin{array}{l}9 \text { Italian } \\
\text { centers } \\
\text { Isolated } \\
\text { infantile } \\
\text { CHD } \\
\text { infantile } 33 \\
\text { (75\%) 11 } \\
\text { (25\%) Age } \\
\text { at diagnosis } \\
\text { (m) 1.7 } \\
\text { (0-41) } 0.3 \\
\text { (0.1-30) } \\
\text { Asymp- } \\
\text { tomatic } 184 \\
\text { CHF } 24 \\
\text { Respiratory } \\
\text { symptoms } \\
\text { 15 } 5 \text { Qp:Qs } \\
\text { 1.45 (1-3) } \\
\text { 1.95 (1-2.8) } \\
\text { mPAP } \\
\text { (mmHg) } 20 \\
\text { (13-34) } 34 \\
\text { (18-50) Coil- } \\
\text { MAPCA } 11 \\
4 \text { Pulmonary } \\
\text { hypoplasia } \\
\text { 17 } 8 \text { Surgery } \\
\text { for other } \\
\text { CHD } 08 \\
\text { Deaths } 02 \\
\text { Respiratory } \\
\text { symptoms } 2 \\
1\end{array}$ & \\
\hline
\end{tabular}




\begin{tabular}{|c|c|c|c|c|c|c|c|}
\hline S.No. & $\begin{array}{l}\text { Authors, } \\
\text { years }\end{array}$ & $\begin{array}{l}\text { Period of } \\
\text { study }\end{array}$ & $\begin{array}{l}\text { No. of } \\
\text { patients }\end{array}$ & Age, sex & $\begin{array}{l}\text { Anatomy } \\
\text { / Coex- } \\
\text { isting } \\
\text { lesions / } \\
\text { Symp- } \\
\text { toms / } \\
\text { Investi- } \\
\text { gations }\end{array}$ & Surgery & $\begin{array}{l}\text { Results/Foll } \\
\text { up }\end{array}$ \\
\hline 40. & $\begin{array}{l}\text { Najm HK et } \\
\text { al, } \\
2018^{\mathrm{E} 62-64}\end{array}$ & $2018-2019$ & 6 & $\begin{array}{l}3 \text { months-65 } \\
\text { years, } \\
\text { median } 40 \\
\text { years }\end{array}$ & $\begin{array}{l}\text { Scimitar } \\
\text { syndrome, } \\
\text { PAPVR- } \\
\text { RUPV, } \\
\text { RMVSVC, } \\
\text { no ASD (3) } \\
\text { Heterotaxy } \\
\text { unbalanced } \\
\text { AVSD, } \\
\text { mixed } \\
\text { obstructed } \\
\text { TAPVR (2) }\end{array}$ & $\begin{array}{l}\text { In situ } \\
\text { pericardial } \\
\text { roll directing } \\
\text { SV to SV } \\
\text { with repair } \\
\text { of } \\
\text { concomitant } \\
\text { cardiac } \\
\text { anomalies }\end{array}$ & $\begin{array}{l}\text { No mortality } \\
\text { Median } \\
\text { hospital stay } \\
23 \text { days } \\
\text { (4-60 days), } \\
\text { median } \\
\text { follow-up } 20 \\
\text { months } \\
\text { (1-36 } \\
\text { months), } \\
\text { widely } \\
\text { patent } \\
\text { PVLA } \\
\text { anastomosis, } \\
\text { all asymp- } \\
\text { tomatic } \\
\text { NYHA-I }\end{array}$ \\
\hline 41. & $\begin{array}{l}\text { Kowatari } \\
\text { R et al, } \\
2016^{\mathrm{E} 65}\end{array}$ & 2016 & 1 & 15 years & $\begin{array}{l}\text { Recurrent } \\
\text { RTI, } \\
\text { CXR- } \\
\text { scimitar } \\
\text { sign, } \\
\text { CT-SV } \\
\text { infradi- } \\
\text { aphrag- } \\
\text { matic } \\
\text { IVC, PAP } \\
28 / 9(15 \\
\text { mmHg) } \\
\text { cath } \\
\text { Qp:Qs } 3.2, \\
\text { PVr } \\
0.7 \mathrm{u} / \mathrm{m}^{2}\end{array}$ & $\begin{array}{l}\text { CPB, car- } \\
\text { dioplegia, } \\
\text {, SVC } \\
\text { with RA, } \\
\text { IVC flap } \\
\text { anasto- } \\
\text { mosed } \\
\text { directly to } \\
\text { right-sided } \\
\text { LA wall }\end{array}$ & $\begin{array}{l}\text { Postoperative } \\
\text { Echo, CT- } \\
\text { no } \\
\text { stenosis / } \\
\text { kinking } \\
\text { scimitar } \\
\text { vein }\end{array}$ \\
\hline
\end{tabular}




\begin{tabular}{|c|c|c|c|c|c|c|c|}
\hline S.No. & $\begin{array}{l}\text { Authors, } \\
\text { years }\end{array}$ & $\begin{array}{l}\text { Period of } \\
\text { study }\end{array}$ & $\begin{array}{l}\text { No. of } \\
\text { patients }\end{array}$ & Age, sex & $\begin{array}{l}\text { Anatomy } \\
\text { / Coex- } \\
\text { isting } \\
\text { lesions / } \\
\text { Symp- } \\
\text { toms / } \\
\text { Investi- } \\
\text { gations }\end{array}$ & Surgery & $\begin{array}{l}\text { Results/Foll } \\
\text { up }\end{array}$ \\
\hline 42. & $\begin{array}{l}\text { Jensen H } \\
\text { et al, } \\
2009^{\mathrm{E} 66}\end{array}$ & 2009-2012 & 6 & $\begin{array}{l}17 \text { years, } 2 \\
\text { years, } 6 \\
\text { months, } \\
11 \text { years, } 1 \\
\text { year, } 7 \\
\text { months }\end{array}$ & $\begin{array}{l}\text { SS, } \\
\text { MAPCA } \\
(2), \\
\text { previous } \\
\text { failed } \\
\text { baffle (1), } \\
\text { moderate } \\
\text { PAH (2), } \\
\text { ASD (4), } \\
\text { PFO (1), } \\
\text { bilateral } \\
\text { SVC (2) }\end{array}$ & $\begin{array}{l}\text { CPB, car- } \\
\text { dioplegia, } \\
\text { SV } \\
\text { transected } \\
\text { at the } \\
\text { junction } \\
\text { of IVC. } \\
\text { Caval end- } \\
\text { sutured, } \\
\text { SV- } \\
\text { tunneled } \\
\text { through a } \\
\text { large } \\
\text { pericardial } \\
\text { opening } \\
\text { posterior } \\
\text { to the } \\
\text { phrenic } \\
\text { nerve- } \\
\text { anasto- } \\
\text { mosed to } \\
\text { the } \\
\text { right-side } \\
\text { of } \\
\text { posterior } \\
\text { LA with } \\
\text { access via } \\
\text { an } \\
\text { existing or } \\
\text { surgically } \\
\text { created } \\
\text { ASD. } \\
\text { CPB } \\
\text { median } 88 \\
\text { minutes, } \\
\text { ACCT } \\
\text { median } 38 \\
\text { minutes }\end{array}$ & $\begin{array}{l}\text { No deaths, } \\
\text { follow-up } \\
\text { median } 28 \\
\text { months } \\
\text { ( } 8 \text {-41 } \\
\text { months), } \\
\text { no reoper- } \\
\text { ation, no } \\
\text { PVO }\end{array}$ \\
\hline
\end{tabular}




\begin{tabular}{|c|c|c|c|c|c|c|c|}
\hline S.No. & $\begin{array}{l}\text { Authors, } \\
\text { years }\end{array}$ & $\begin{array}{l}\text { Period of } \\
\text { study }\end{array}$ & $\begin{array}{l}\text { No. of } \\
\text { patients }\end{array}$ & Age, sex & $\begin{array}{l}\text { Anatomy } \\
\text { / Coex- } \\
\text { isting } \\
\text { lesions / } \\
\text { Symp- } \\
\text { toms / } \\
\text { Investi- } \\
\text { gations }\end{array}$ & Surgery & $\begin{array}{l}\text { Results/Foll } \\
\text { up }\end{array}$ \\
\hline 43. & $\begin{array}{l}\text { Lugones I } \\
\text { et al, } \\
2017^{\mathrm{E} 67}\end{array}$ & 2017 & 1 & $\begin{array}{l}2 \text { years } \\
\text { male }\end{array}$ & $\begin{array}{l}\text { SS, CXR- } \\
\text { destrocar- } \\
\text { dia, } \\
\text { car- } \\
\text { diomegaly, } \\
\text { increased } \\
\text { PBF, } \\
\text { hypoplasia } \\
\text { right lung, } \\
\text { Echo-RV, } \\
\text { RA } \\
\text { dilatation, } \\
\text { no ASD, } \\
\text { SV } \\
\text { draining } \\
\text { whole } \\
\text { right lung } \\
\text { infradi- } \\
\text { aphrag- } \\
\text { matic, } \\
\text { IVC- } \\
\text { stenotic } \\
\text { opening, } \\
\text { Cath } \\
\text { Qp:Qs } \\
\text { 1.8:1, } \\
\text { MAPCAs- } \\
\text { occluded }\end{array}$ & $\begin{array}{l}\text { CPB, car- } \\
\text { dioplegia, } \\
\text { in situ } \\
\text { pericardial } \\
\text { rerouting } \\
\text { in which } \\
\text { the SV } \\
\text { was } \\
\text { detached } \\
\text { from its } \\
\text { insertion } \\
\text { line and } \\
\text { the atrial } \\
\text { septum } \\
\text { was repo- } \\
\text { sitioned to } \\
\text { create a } \\
\text { large } \\
\text { opening } \\
\text { into the } \\
\text { LA. SV } \\
\text { drained to } \\
\text { a } \\
\text { pericardial } \\
\text { bag } \\
\text { connected } \\
\text { to the LA }\end{array}$ & $\begin{array}{l}\text { Surgived } \\
\text { TEE, } \\
\text { Cath- un- } \\
\text { obstructed } \\
\text { anastomo- } \\
\text { sis, } \\
\text { discharged } \\
\text { on } 4^{\text {th }} \\
\text { postopera- } \\
\text { tive } \\
\text { day }\end{array}$ \\
\hline
\end{tabular}




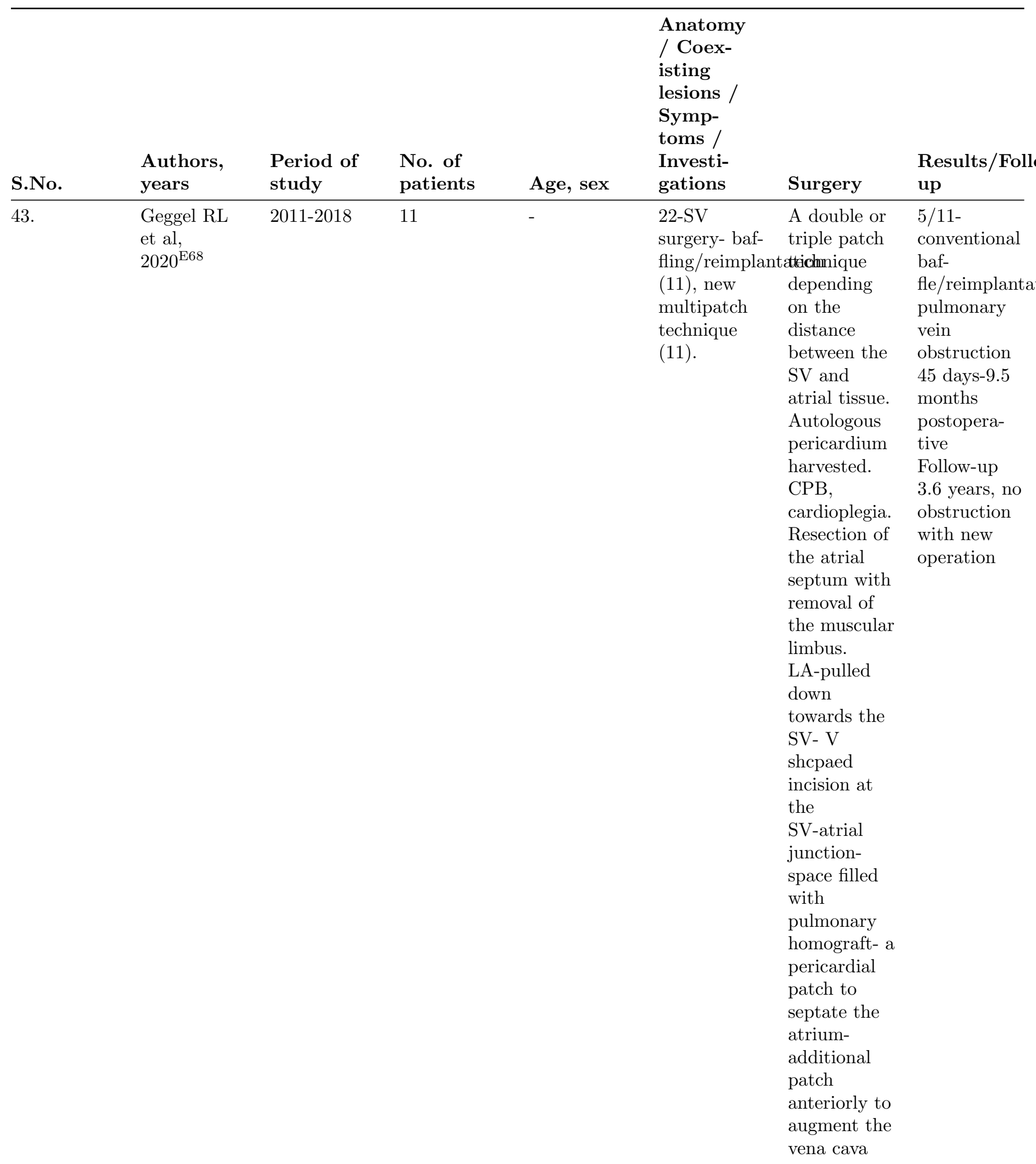




\begin{tabular}{|c|c|c|c|c|c|c|c|}
\hline S.No. & $\begin{array}{l}\text { Authors, } \\
\text { years }\end{array}$ & $\begin{array}{l}\text { Period of } \\
\text { study }\end{array}$ & $\begin{array}{l}\text { No. of } \\
\text { patients }\end{array}$ & Age, sex & $\begin{array}{l}\text { Anatomy } \\
\text { / Coex- } \\
\text { isting } \\
\text { lesions / } \\
\text { Symp- } \\
\text { toms / } \\
\text { Investi- } \\
\text { gations }\end{array}$ & Surgery & $\begin{array}{l}\text { Results/Foll } \\
\text { up }\end{array}$ \\
\hline 44. & $\begin{array}{l}\text { Sun Y et al, } \\
2018^{\mathrm{E} 69}\end{array}$ & $2011-2017$ & 9 & $\begin{array}{l}\text { Male } 4 \text { Age: } \\
3.1 \pm 3.6 \\
\text { mean (range } \\
0.3-12 \\
\text { years), } \\
\text { Infantile } \\
\text { form (4), } \\
\text { childhood } \\
\text { adult (4) }\end{array}$ & $\begin{array}{l}\text { Vertical } \\
\text { form of } \\
\text { SV-IVC, CT } \\
(9) \text {, Echo } \\
(9+) \text {, Cath } \\
(5) \text {; PDA } \\
(4), \text { ASD } \\
(9), \text { VSD } \\
(1), \\
\text { MAPCA } \\
(3), \text { de- } \\
\text { stroposition } \\
(9), \text { right } \\
\text { lung } \\
\text { hypoplasia } \\
\text { (7) }\end{array}$ & $\begin{array}{l}\text { SV- } \\
\text { transected } \\
\text { from IVC- } \\
\text { attached to } \\
\text { the right } \\
\text { lateral } \\
\text { pericardium- } \\
\text { left } \\
\text { atriotomy. } \\
\text { The } \\
\text { pericardial } \\
\text { flap is } \\
\text { turned to } \\
\text { the left with } \\
\text { its anterior } \\
\text { margin } \\
\text { sutured on } \\
\text { the free wall } \\
\text { of the RA } \\
\text { anterior to } \\
\text { the IA } \\
\text { groove to } \\
\text { create a } \\
\text { tunnel. }\end{array}$ & $\begin{array}{l}\text { No hospital } \\
\text { death, no } \\
\text { residual SV } \\
\text { obstruction, } \\
1 \text { lost to } \\
\text { follow-up, } 8 \\
\text { survivors } \\
\text { follow-up } \\
33.4 \pm 19.2 \\
(2-72) \\
\text { months, no } \\
\text { PH, No SV } \\
\text { obstruction }\end{array}$ \\
\hline
\end{tabular}




\begin{tabular}{|c|c|c|c|c|c|c|c|}
\hline S.No. & $\begin{array}{l}\text { Authors, } \\
\text { years }\end{array}$ & $\begin{array}{l}\text { Period of } \\
\text { study }\end{array}$ & $\begin{array}{l}\text { No. of } \\
\text { patients }\end{array}$ & Age, sex & $\begin{array}{l}\text { Anatomy } \\
\text { / Coex- } \\
\text { isting } \\
\text { lesions / } \\
\text { Symp- } \\
\text { toms / } \\
\text { Investi- } \\
\text { gations }\end{array}$ & Surgery & $\begin{array}{l}\text { Results/Foll } \\
\text { up }\end{array}$ \\
\hline 45. & $\begin{array}{l}\text { Vida L et al } \\
2020^{\mathrm{E} 72}\end{array}$ & - & $\begin{array}{l}485 \text { (51 } \\
\text { European } \\
\text { Centres) }\end{array}$ & $\begin{array}{l}\text { SS patients, } \\
\text { overall } \\
(485), \\
\text { neonates/infar } \\
(282), \\
\text { children } \\
>1-10 \text { years } \\
(113), \\
\text { adoles- } \\
\text { cents/adults } \\
>10 \text { years } \\
(90) .\end{array}$ & $\begin{array}{l}\text { SS, } \\
\text { dextrocardia } \\
240, \\
\text { tosocardia } \\
(83), \\
\text { levocardia } \\
(163), \\
\text { isolated } \\
(186), \\
\text { associated } \\
\text { CHD (299), } \\
\text { right } \\
\text { pulmonary } \\
\text { hypoplasia } \\
\text { (346), PA } \\
\text { hypoplasia- } \\
\text { severe (46), } \\
\text { preoperative } \\
\text { cardiac } \\
\text { symptoms } \\
(277), \\
\text { respiratory } \\
\text { symptoms } \\
(24), \text { pH } \\
(157), \\
\text { embolization } \\
\text { MAPCAs } \\
(177)\end{array}$ & $\begin{array}{l}\text { STP }(279), \\
\text { CMP (206), } \\
\text { follow-up } 72 \\
\text { years (range } \\
2.2-14 \text { years) }\end{array}$ & $\begin{array}{l}\text { STP, } \\
\text { hospital } \\
\text { death } 29 \\
(10 \%), \text { late } \\
\text { mortality } 11 \\
(3.9 \%), \\
\text { symptoms at } \\
\text { last } \\
\text { follow-up } \\
172(37 \%) .\end{array}$ \\
\hline
\end{tabular}

[Abbreviations: ACCT: Aortic cross clamp time; ALCAPA: Anomalous origin of left coronary artery from the pulmonary artery; ASD: Atrial septal defect; ATL: Anterior tricuspid leaflet; CHF: Congestive heart failure; COA: Coarctation of aorta; CPB: Cardiopulmonary bypass; CPBT: Cardiopulmonary bypass time; CXR: Chest x-ray; DORV: Double outlet right ventricle; ECMO: Extracorporeal membrane oxygenation; ESM: Ejection systolic murmur; HLHS: Hypoplastic left heart syndrome; HMD: Hyaline membrane disease; ICR: Intracardiac repair; IQR: Interquartile range; IVC: Inferior caval vein; LA: Left atrium; LV: Left ventricle; MAPCAs: Major aortopulmonary collateral arteries; MRA: Magnetic resonance angiography; MRI: Magnetic resonance imaging; MV: Mitral valve; NYHA: New Yori Heart Association; OS: Ostium secundum; PAH: Pulmonary artery hypertension; PAP: Pulmonary artery pressure; PDA: Persistent arterial duct; PTFE: Polytetrafluoroethylene; PV: Pulmonary vein; PVR: Pulmonary vascular; resistance PVR: Pulmonary vascular resistance; Qp:Qs: Pulmonary blood flow / systemic bloow flow; RA: Right atrium; RAA: Right aortic arch; RALT: Right anterolateral thoracotomy; RPA: Right pulmonary artery; RSPV: Right superior pulmonary vein; RTI: Respiratory tract infection; RVMB: Right ventricular muscle bundle; 
SCPC: Superior cavopulmonary connection; SS: scimitar syndrome; STP: Surgically treated patients; SV: scimitar vein; TA: Tricuspid atresia; TCPC: Totally cavopulmonary connection; TEE: Transesophageal echocardiography; TGA: Transposition of the great arteries; TOF: Tetralogy of fallot; UVH: Univentricular heart; VACTERL: Vertebral anal cardiac tracheal esophageal rectal laryngeal; VSD: Ventricular septal defect]

Table E2: Summary of the published investigations documenting the surgical anatomy, associated cardiac lesions, indications for different types of operation for patients with scimitar syndrome

\begin{tabular}{|c|c|c|c|}
\hline S. No. & $\begin{array}{l}\text { Operations } \\
\text { performed }\end{array}$ & $\begin{array}{l}\text { Indications, surgical } \\
\text { anatomy, associated } \\
\text { anomalies, surgical } \\
\text { details }\end{array}$ & References \\
\hline 1. & $\begin{array}{l}\text { Division and } \\
\text { reimplantation of the } \\
\text { scimitar vein into the } \\
\text { right atrium with CPB }\end{array}$ & $\begin{array}{l}\text { Short length scimitar } \\
\text { vein Not long enough for } \\
\text { direct anastomosis to left } \\
\text { atrium SVRA } \\
\text { anastomosis plus Bailey;s } \\
\text { atrioseptopexy }\end{array}$ & $18, \mathrm{E} 3$ \\
\hline 2. & $\begin{array}{l}\text { Division and } \\
\text { translocation of the } \\
\text { scimilar vein into the } \\
\text { right atrium }\end{array}$ & $\begin{array}{l}\text { scimitar vein division and } \\
\text { translocation to } \\
\text { posterolateral wall - RA } \\
\text { adjacent to pre-existing } \\
\text { ASD or newly created } \\
\text { ASD Short baffle } \\
\text { Associated stenosis- SV if } \\
\text { present, spatulated and } \\
\text { caval cuff IVC- patch to } \\
\text { avoid stenosis }\end{array}$ & 13,19,E5,E6 \\
\hline 3. & $\begin{array}{l}\text { Division and } \\
\text { translocation of the } \\
\text { scimitar vein into left } \\
\text { atrium }\end{array}$ & $\begin{array}{l}\text { Right anterolateral } \\
\text { thoracotomy, no CPB } \\
\text { Direct anastomosis to LA } \\
\text { after division and } \\
\text { translocation scimitar } \\
\text { vein divided with caval } \\
\text { cuff Not associated ASD } \\
\text { Both infants and adults }\end{array}$ & $\mathrm{E} 2, \mathrm{E} 6, \mathrm{E} 8$ \\
\hline 4. & $\begin{array}{l}\text { Division and } \\
\text { translocation of the } \\
\text { scimitar vein into LA } \\
\text { using PTFE graft } \\
\text { interposition }\end{array}$ & $\begin{array}{l}\text { Short length of the } \\
\text { scimitar vein Median } \\
\text { sternotomy under CPB }\end{array}$ & 39 \\
\hline 5. & $\begin{array}{l}\text { Division and } \\
\text { translocation into left } \\
\text { atrium using Dacron } \\
\text { graft interposition }\end{array}$ & $\begin{array}{l}\text { Right thoracotomy No } \\
\text { ASD } 20 \text { mm Dacron } \\
\text { graft- short length } \\
\text { scimitar vein }\end{array}$ & 7,19 \\
\hline
\end{tabular}




\begin{tabular}{|c|c|c|c|}
\hline S. No. & $\begin{array}{l}\text { Operations } \\
\text { performed }\end{array}$ & $\begin{array}{l}\text { Indications, surgical } \\
\text { anatomy, associated } \\
\text { anomalies, surgical } \\
\text { details }\end{array}$ & References \\
\hline 6. & $\begin{array}{l}\text { Division and } \\
\text { translocation of the } \\
\text { scimitar vein into LA via } \\
\text { pericardial tunnel }\end{array}$ & $\begin{array}{l}\text { Short length scimitar } \\
\text { vein Division of the } \\
\text { scimitar vein at SV-IVC } \\
\text { confluence with caval cuff } \\
\text { CPB-SV to pericardial } \\
\text { anastomosis Circulatory } \\
\text { arrest - Left atriotomy- } \\
\text { pericardial margins } \\
\text { sutured to the left } \\
\text { atriotomy and freewall of } \\
\text { the RA }\end{array}$ & E10 \\
\hline 7. & $\begin{array}{l}\text { Partitioning of the } \\
\text { inferior caval vein and } \\
\text { rechanneling of the } \\
\text { scimitar vein into the LA }\end{array}$ & $\begin{array}{l}\text { No associated ASD } \\
\text { DHCA at } 18^{\circ} \mathrm{C} \text { Inferior } \\
\text { cavoatrial junction - } \\
\text { transected Pericardial } \\
\text { patch partitioning into } \\
\text { anterior and posterior } \\
\text { compartments Posterior } \\
\text { receiving SV blood, } \\
\text { anterior compartment - } \\
\text { caval blood Infantile } \\
\text { variety }\end{array}$ & E11 \\
\hline 8. & Intra-atrial baffle & $\begin{array}{l}\text { Useful in adults Long, } \\
\text { intra-atrial baffle of } \\
\text { PTFE or right atrial wall } \\
\text { or pericardium From the } \\
\text { orifice of the scimitar } \\
\text { vein, across the atrial } \\
\text { septal defect Under } \\
\text { circulatory arrest }\end{array}$ & E12 \\
\hline 9. & $\begin{array}{l}\text { Atrial septectomy and } \\
\text { intra-atrial baffling }\end{array}$ & $\begin{array}{l}\text { scimitar syndrome with } \\
\text { intact interatrial septum }\end{array}$ & E14 \\
\hline 10. & $\begin{array}{l}\text { Scimitar vein cut back } \\
\text { technique }\end{array}$ & $\begin{array}{l}\text { SV to RA cut back along } \\
\text { with venoatrial junction } \\
\text { Angle away from the } \\
\text { anastomosis Decreasing } \\
\text { the risk of local stenosis }\end{array}$ & \\
\hline 11 & $\begin{array}{l}\text { In situ pericardial roll } \\
\text { technique for distant } \\
\text { anomalous pulmonary } \\
\text { venous return }\end{array}$ & $\begin{array}{l}\text { Using both anterior and } \\
\text { posterior configuration } \\
\text { for anomalous SV that } \\
\text { are distant from the LA } \\
\text { either because of remote } \\
\text { insertion, because of } \\
\text { complex cardiac anatomy }\end{array}$ & E64 \\
\hline
\end{tabular}




\begin{tabular}{|c|c|c|c|}
\hline S. No. & $\begin{array}{l}\text { Operations } \\
\text { performed }\end{array}$ & $\begin{array}{l}\text { Indications, surgical } \\
\text { anatomy, associated } \\
\text { anomalies, surgical } \\
\text { details }\end{array}$ & References \\
\hline 12 & $\begin{array}{l}\text { Division and } \\
\text { translocation of the SV } \\
\text { into LA with SV flap }\end{array}$ & $\begin{array}{l}\text { Median sternotomy, } \\
\text { CPB, Cardioplegic arrest } \\
\text { SV was harvested with } \\
\text { the surrounding IVC and } \\
\text { RA wall as SV flap The } \\
\text { SV flap was anastomosed } \\
\text { directly to the LA }\end{array}$ & E65 \\
\hline 13 & $\begin{array}{l}\text { Modified in situ } \\
\text { pericardial rerouting and } \\
\text { repositioning of the atrial } \\
\text { septum }\end{array}$ & $\begin{array}{l}\text { Useful in case of SS with } \\
\text { dextrocardia or mal } \\
\text { rotation of the heart with } \\
\text { or without pulmonary } \\
\text { venous obstruction }\end{array}$ & E67 \\
\hline 14 & $\begin{array}{l}\text { Directly implantation of } \\
\text { the SV to the LA via } \\
\text { sternotomy }\end{array}$ & $\begin{array}{l}\text { Under cardioplegic } \\
\text { arrest, SV was transected } \\
\text { and brought through a } \\
\text { large pericardial opening } \\
\text { posterior to the phrenic } \\
\text { narve Anastomosed to } \\
\text { LA with access via ASD }\end{array}$ & E66 \\
\hline 15 & $\begin{array}{l}\text { Repair by a novel } \\
\text { multipatch technique }\end{array}$ & $\begin{array}{l}\text { Under cardioplegic } \\
\text { arrest, resection of the } \\
\text { atrial septum, a double } \\
\text { or triple patch technique } \\
\text { depending on the } \\
\text { distance between the SV } \\
\text { and atrial tissue Avoids } \\
\text { circuitous pathways or } \\
\text { tension on the scimitar } \\
\text { pulmonary vein }\end{array}$ & E68 \\
\hline 16 & $\begin{array}{l}\text { Pericardial tunnel } \\
\text { technique }\end{array}$ & $\begin{array}{l}\text { Under cardioplegic } \\
\text { arrest, SV was divided at } \\
\text { ifs insertion site on the } \\
\text { IVE The proximal and } \\
\text { was oversewn The distal } \\
\text { end was filleted open } \\
\text { longitudianally on ifs } \\
\text { medial aspect The SV } \\
\text { was attached to the right } \\
\text { lateral pericardium using } \\
\text { 7-O polydioxanone suture } \\
\text { Blood flow was directed } \\
\text { to LA through a left } \\
\text { atritomy inside the } \\
\text { pericardial tunnel }\end{array}$ & E69 \\
\hline
\end{tabular}




\begin{tabular}{|c|c|c|c|}
\hline S. No. & $\begin{array}{l}\text { Operations } \\
\text { performed }\end{array}$ & $\begin{array}{l}\text { Indications, surgical } \\
\text { anatomy, associated } \\
\text { anomalies, surgical } \\
\text { details }\end{array}$ & References \\
\hline 17 & $\begin{array}{l}\text { Divison and translocation } \\
\text { of the SV into LA using a } \\
\text { ringed PTFE conduit }\end{array}$ & $\begin{array}{l}\text { Under CPB, cardioplegic } \\
\text { arrest Distal and of SV } \\
\text { was transected and } \\
\text { mobilized A ringed PTFE } \\
\text { interposition graph was } \\
\text { sewn ent-to-end the } \\
\text { divided SV and the other } \\
\text { end was anastomosed end } \\
\text { to side to the LA }\end{array}$ & E70 \\
\hline 18. & Pneumonectomy & $\begin{array}{l}\text { scimitar vein coursing } \\
\text { posterior to the hilum } \\
\text { Post repair- stenosed, } \\
\text { fibrosed scimitar vein } \\
\text { Recurrent stenosis of the } \\
\text { pulmonary vein following } \\
\text { dilatation / stenting }\end{array}$ & E15,E17 \\
\hline 19. & $\begin{array}{l}\text { Lobectomy / lung } \\
\text { resection }\end{array}$ & $\begin{array}{l}\text { Persistent right-sided } \\
\text { pneumonia on a grossly } \\
\text { hypoplastic lung } \\
\text { Sequestration of the } \\
\text { pulmonary parenchyma }\end{array}$ & E17,E18 \\
\hline 20. & Lung transplantation & $\begin{array}{l}\text { Persistent postoperative } \\
\text { pulmonary hypertension } \\
\text { Recurrent pulmonary } \\
\text { vein stenosis following } \\
\text { surgery for scimitar vein }\end{array}$ & $9, \mathrm{E} 2$ \\
\hline 21. & $\begin{array}{l}\text { Orthotopic cardiac } \\
\text { transplantation }\end{array}$ & $\begin{array}{l}\text { scimitar syndrome with a } \\
\text { functionally } \\
\text { univentricular heart with } \\
\text { severely hypoplastic } \\
\text { pulmonary artery }\end{array}$ & 13,E19 \\
\hline 22 & $\begin{array}{l}\text { Coil embolization / } \\
\text { surgical ligation / balloon } \\
\text { angioplasty }\end{array}$ & $\begin{array}{l}\text { Sizeable MAPCAs } \\
\text { Infants via axillary } \\
\text { artery, juvenile / adults- } \\
\text { femoral artery Mini } \\
\text { balloon Balloon } \\
\text { expandable stainless steel } \\
\text { Palmaz stent - for } \\
\text { stenotic pulmonary vein } \\
\text { or stenosed baffle }\end{array}$ & 9,13,19,E2,E20-E24 \\
\hline
\end{tabular}

[Abbreviations: ASD: Atrial septal defect; CPB: Cardiopulmonary bypass; DHCA: Deep hypothermic circulatory arrest; IVC: Inferior caval vein; LA: Left atrium; MAPCAs: Major aortopulmonary collateral arteries; PTFE: Polytetrafluoroethylene; RA: Right atrium; SV: scimitar vein]

Table E3: Early and late postoperative outcomes of the patients undergoing different types of operation for patients with scimitar syndrome in the published investigations 


\begin{tabular}{|c|c|c|c|c|c|c|c|c|}
\hline Variables & Results & Results & Results & Results & Results & Results & Results & Refere \\
\hline $\begin{array}{l}\text { Short- } \\
\text { term } \\
\text { out- } \\
\text { comes }\end{array}$ & $\begin{array}{l}\text { Short- } \\
\text { term } \\
\text { out- } \\
\text { comes }\end{array}$ & $\begin{array}{l}\text { Short- } \\
\text { term } \\
\text { out- } \\
\text { comes }\end{array}$ & $\begin{array}{l}\text { Short- } \\
\text { term } \\
\text { out- } \\
\text { comes }\end{array}$ & $\begin{array}{l}\text { Short- } \\
\text { term } \\
\text { out- } \\
\text { comes }\end{array}$ & $\begin{array}{l}\text { Short- } \\
\text { term } \\
\text { out- } \\
\text { comes }\end{array}$ & $\begin{array}{l}\text { Short- } \\
\text { term } \\
\text { out- } \\
\text { comes }\end{array}$ & $\begin{array}{l}\text { Short- } \\
\text { term } \\
\text { out- } \\
\text { comes }\end{array}$ & \\
\hline Overall & Overall & Overall & Overall & Overall & Overall & Overall & Overall & \\
\hline $\begin{array}{l}\text { opera- } \\
\text { tive }\end{array}$ & $\begin{array}{l}\text { opera- } \\
\text { tive }\end{array}$ & $\begin{array}{l}\text { opera- } \\
\text { tive }\end{array}$ & $\begin{array}{l}\text { opera- } \\
\text { tive }\end{array}$ & $\begin{array}{l}\text { opera- } \\
\text { tive }\end{array}$ & $\begin{array}{l}\text { opera- } \\
\text { tive }\end{array}$ & $\begin{array}{l}\text { opera- } \\
\text { tive }\end{array}$ & $\begin{array}{l}\text { opera- } \\
\text { tive }\end{array}$ & \\
\hline mortal- & mortal- & mortal- & mortal- & mortal- & mortal- & mortal- & mortal- & \\
\hline ity: & ity: & ity: & ity: & ity: & ity: & ity: & ity: & \\
\hline $4.8 \%-$ & $4.8 \%-$ & $4.8 \%-$ & $4.8 \%-$ & $4.8 \%-$ & $4.8 \%-$ & $4.8 \%-$ & $4.8 \%-$ & \\
\hline $5.9 \%$ & $5.9 \%$ & $5.9 \%$ & $5.9 \%$ & $5.9 \%$ & $5.9 \%$ & $5.9 \%$ & $5.9 \%$ & \\
\hline Causes & Causes & Causes & Causes & Causes & Causes & Causes & Causes & \\
\hline of & of & of & of & of & of & of & of & \\
\hline death: & death: & death: & death: & death: & death: & death: & death: & \\
\hline Infantile & Infantile & Infantile & Infantile & Infantile & Infantile & Infantile & Infantile & \\
\hline presen- & presen- & presen- & presen- & presen- & presen- & presen- & presen- & \\
\hline with as- & with as- & with as- & with as- & with as- & with as- & with as- & with as- & \\
\hline sociated & sociated & sociated & sociated & sociated & sociated & sociated & sociated & \\
\hline complex & complex & complex & complex & complex & complex & complex & complex & \\
\hline CHDs, & CHDs, & CHDs, & CHDs, & CHDs, & CHDs, & CHDs, & CHDs, & \\
\hline severe & severe & severe & severe & severe & severe & severe & severe & \\
\hline pul- & pul- & pul- & pul- & pul- & pul- & pul- & pul- & \\
\hline monary & monary & monary & monary & monary & monary & monary & monary & \\
\hline hyper- & hyper- & hyper- & hyper- & hyper- & hyper- & hyper- & hyper- & \\
\hline $\begin{array}{l}\text { tension, } \\
\text { major }\end{array}$ & $\begin{array}{l}\text { tension, } \\
\text { major }\end{array}$ & $\begin{array}{l}\text { tension, } \\
\text { major }\end{array}$ & $\begin{array}{l}\text { tension, } \\
\text { major }\end{array}$ & $\begin{array}{l}\text { tension, } \\
\text { major }\end{array}$ & $\begin{array}{l}\text { tension, } \\
\text { major }\end{array}$ & $\begin{array}{l}\text { tension, } \\
\text { major }\end{array}$ & $\begin{array}{l}\text { tension, } \\
\text { major }\end{array}$ & \\
\hline associ- & associ- & associ- & associ- & associ- & associ- & associ- & associ- & \\
\hline ated & ated & ated & ated & ated & ated & ated & ated & \\
\hline extrac- & extrac- & extrac- & extrac- & extrac- & extrac- & extrac- & extrac- & \\
\hline ardiac & ardiac & ardiac & ardiac & ardiac & ardiac & ardiac & ardiac & \\
\hline anoma- & anoma- & anoma- & anoma- & anoma- & anoma- & anoma- & anoma- & \\
\hline lies, & lies, & lies, & lies, & lies, & lies, & lies, & lies, & \\
\hline severe & severe & severe & severe & severe & severe & severe & severe & \\
\hline pul- & pul- & pul- & pul- & pul- & pul- & pul- & pul- & \\
\hline monary & monary & monary & monary & monary & monary & monary & monary & \\
\hline hy- & hy- & hy- & hy- & hy- & hy- & hy- & hy- & \\
\hline poplasia & poplasia & poplasia & poplasia & poplasia & poplasia & poplasia & poplasia & \\
\hline with & with & with & with & with & with & with & with & \\
\hline seques- & seques- & seques- & seques- & seques- & seques- & seques- & seques- & \\
\hline tration, & tration, & tration, & tration, & tration, & tration, & tration, & tration, & \\
\hline hy- & hy- & hy- & hy- & hy- & hy- & & hy- & \\
\hline poplas- & poplas- & poplas- & poplas- & poplas- & poplas- & poplas- & poplas- & \\
\hline tic left & tic left & tic left & tic left & tic left & tic left & tic left & tic left & \\
\hline heart & heart & heart & heart & heart & heart & heart & heart & \\
\hline syndrome & syndrome & syndrome & syndrome & syndrome & syndrome & syndrome & syndrome & \\
\hline Long- & Long- & Long- & Long- & Long- & Long- & Long- & Long- & \\
\hline term & term & term & term & term & term & term & term & \\
\hline out- & out- & out- & out- & out- & out- & out- & out- & \\
\hline comes & comes & comes & comes & comes & comes & comes & comes & \\
\hline
\end{tabular}




\begin{tabular}{|c|c|c|c|c|c|c|c|c|}
\hline Variables & Results & Results & Results & Results & Results & Results & Results & Refere \\
\hline $\begin{array}{l}\text { Schramel } \\
\text { et al, } \\
1995\end{array}$ & $\begin{array}{l}\mathrm{N}=7 \text {, no } \\
\text { surgery } \\
(3), \\
\text { reim- } \\
\text { planta- } \\
\text { tion of } \\
\text { SV into } \\
\text { LA, re- } \\
\text { section } \\
\text { of the } \\
\text { se- } \\
\text { questered } \\
\text { lobe (2), } \\
\text { postop- } \\
\text { erative } \\
\text { fibrosed, } \\
\text { stenosed } \\
\text { SV } \\
\text { needing } \\
\text { pneu- } \\
\text { monec- } \\
\text { tomy } \\
\text { (2) }\end{array}$ & $\begin{array}{l}\text { N=7, no } \\
\text { surgery } \\
(3), \\
\text { reim- } \\
\text { planta- } \\
\text { tion of } \\
\text { SV into } \\
\text { LA, re- } \\
\text { section } \\
\text { of the } \\
\text { se- } \\
\text { questered } \\
\text { lobe (2), } \\
\text { postop- } \\
\text { erative } \\
\text { fibrosed, } \\
\text { stenosed } \\
\text { SV } \\
\text { needing } \\
\text { pneu- } \\
\text { monec- } \\
\text { tomy } \\
(2)\end{array}$ & $\begin{array}{l}\mathrm{N}=7, \text { no } \\
\text { surgery } \\
(3), \\
\text { reim- } \\
\text { planta- } \\
\text { tion of } \\
\text { SV into } \\
\text { LA, re- } \\
\text { section } \\
\text { of the } \\
\text { se- } \\
\text { questered } \\
\text { lobe (2), } \\
\text { postop- } \\
\text { erative } \\
\text { fibrosed, } \\
\text { stenosed } \\
\text { SV } \\
\text { needing } \\
\text { pneu- } \\
\text { monec- } \\
\text { tomy } \\
\text { (2) }\end{array}$ & $\begin{array}{l}\text { N=7, no } \\
\text { surgery } \\
(3), \\
\text { reim- } \\
\text { planta- } \\
\text { tion of } \\
\text { SV into } \\
\text { LA, re- } \\
\text { section } \\
\text { of the } \\
\text { se- } \\
\text { questered } \\
\text { lobe (2), } \\
\text { postop- } \\
\text { erative } \\
\text { fibrosed, } \\
\text { stenosed } \\
\text { SV } \\
\text { needing } \\
\text { pneu- } \\
\text { monec- } \\
\text { tomy } \\
\text { (2) }\end{array}$ & $\begin{array}{l}\text { N=7, no } \\
\text { surgery } \\
(3), \\
\text { reim- } \\
\text { planta- } \\
\text { tion of } \\
\text { SV into } \\
\text { LA, re- } \\
\text { section } \\
\text { of the } \\
\text { se- } \\
\text { questered } \\
\text { lobe (2), } \\
\text { postop- } \\
\text { erative } \\
\text { fibrosed, } \\
\text { stenosed } \\
\text { SV } \\
\text { needing } \\
\text { pneu- } \\
\text { monec- } \\
\text { tomy } \\
\text { (2) }\end{array}$ & $\begin{array}{l}\text { N=7, no } \\
\text { surgery } \\
(3), \\
\text { reim- } \\
\text { planta- } \\
\text { tion of } \\
\text { SV into } \\
\text { LA, re- } \\
\text { section } \\
\text { of the } \\
\text { se- } \\
\text { questered } \\
\text { lobe (2), } \\
\text { postop- } \\
\text { erative } \\
\text { fibrosed, } \\
\text { stenosed } \\
\text { SV } \\
\text { needing } \\
\text { pneu- } \\
\text { monec- } \\
\text { tomy } \\
\text { (2) }\end{array}$ & $\begin{array}{l}\text { N=7, no } \\
\text { surgery } \\
(3), \\
\text { reim- } \\
\text { planta- } \\
\text { tion of } \\
\text { SV into } \\
\text { LA, re- } \\
\text { section } \\
\text { of the } \\
\text { se- } \\
\text { questered } \\
\text { lobe (2), } \\
\text { postop- } \\
\text { erative } \\
\text { fibrosed, } \\
\text { stenosed } \\
\text { SV } \\
\text { needing } \\
\text { pneu- } \\
\text { monec- } \\
\text { tomy } \\
\text { (2) }\end{array}$ & E17 \\
\hline
\end{tabular}




\begin{tabular}{|c|c|c|c|c|c|c|c|c|}
\hline Variables & Results & Results & Results & Results & Results & Results & Results & Refere \\
\hline $\begin{array}{l}\text { Dusenbery } \\
\text { et al, } \\
2013\end{array}$ & $\begin{array}{l}\text { N=80 } \\
(<1 \\
\text { year=56), } \\
\text { MAPCA } \\
\text { ipsilat- } \\
\text { eral } \\
\text { lung } \\
\text { (56), } \\
\text { coil em- } \\
\text { boliza- } \\
\text { tion } \\
(31), \\
\text { surgical } \\
\text { ligation } \\
(12), \text { no } \\
\text { inter- } \\
\text { vention } \\
(13), \text { SV } \\
\text { surgery: } \\
13 / 28 \\
\text { with } \\
\text { baffle } \\
\text { proce- } \\
\text { dure, } \\
5 / 8 \text { with } \\
\text { reim- } \\
\text { planta- } \\
\text { tion } \\
\text { proce- } \\
\text { dure } \\
\text { had } \\
\text { postop- } \\
\text { erative } \\
\text { SV } \\
\text { stenosis }\end{array}$ & $\begin{array}{l}\text { N=80 } \\
(<1 \\
\text { year=56), } \\
\text { MAPCA } \\
\text { ipsilat- } \\
\text { eral } \\
\text { lung } \\
\text { (56), } \\
\text { coil em- } \\
\text { boliza- } \\
\text { tion } \\
\text { (31), } \\
\text { surgical } \\
\text { ligation } \\
\text { (12), no } \\
\text { inter- } \\
\text { vention } \\
(13), \text { SV } \\
\text { surgery: } \\
\text { 13/28 } \\
\text { with } \\
\text { baffle } \\
\text { proce- } \\
\text { dure, } \\
5 / 8 \text { with } \\
\text { reim- } \\
\text { planta- } \\
\text { tion } \\
\text { proce- } \\
\text { dure } \\
\text { had } \\
\text { postop- } \\
\text { erative } \\
\text { SV } \\
\text { stenosis }\end{array}$ & $\begin{array}{l}\text { N=80 } \\
(<1 \\
\text { year=56), } \\
\text { MAPCA } \\
\text { ipsilat- } \\
\text { eral } \\
\text { lung } \\
\text { (56), } \\
\text { coil em- } \\
\text { boliza- } \\
\text { tion } \\
(31), \\
\text { surgical } \\
\text { ligation } \\
(12), \text { no } \\
\text { inter- } \\
\text { vention } \\
(13), \text { SV } \\
\text { surgery: } \\
\text { 13/28 } \\
\text { with } \\
\text { baffle } \\
\text { proce- } \\
\text { dure, } \\
5 / 8 \text { with } \\
\text { reim- } \\
\text { planta- } \\
\text { tion } \\
\text { proce- } \\
\text { dure } \\
\text { had } \\
\text { postop- } \\
\text { erative } \\
\text { SV } \\
\text { stenosis }\end{array}$ & $\begin{array}{l}\text { N=80 } \\
(<1 \\
\text { year=56), } \\
\text { MAPCA } \\
\text { ipsilat- } \\
\text { eral } \\
\text { lung } \\
\text { (56), } \\
\text { coil em- } \\
\text { boliza- } \\
\text { tion } \\
\text { (31), } \\
\text { surgical } \\
\text { ligation } \\
\text { (12), no } \\
\text { inter- } \\
\text { vention } \\
(13), \text { SV } \\
\text { surgery: } \\
13 / 28 \\
\text { with } \\
\text { baffle } \\
\text { proce- } \\
\text { dure, } \\
5 / 8 \text { with } \\
\text { reim- } \\
\text { planta- } \\
\text { tion } \\
\text { proce- } \\
\text { dure } \\
\text { had } \\
\text { postop- } \\
\text { erative } \\
\text { SV } \\
\text { stenosis }\end{array}$ & $\begin{array}{l}\text { N=80 } \\
(<1 \\
\text { year=56), } \\
\text { MAPCA } \\
\text { ipsilat- } \\
\text { eral } \\
\text { lung } \\
\text { (56), } \\
\text { coil em- } \\
\text { boliza- } \\
\text { tion } \\
(31), \\
\text { surgical } \\
\text { ligation } \\
\text { (12), no } \\
\text { inter- } \\
\text { vention } \\
(13) \text { SV } \\
\text { surgery: } \\
\text { 13/28 } \\
\text { with } \\
\text { baffle } \\
\text { proce- } \\
\text { dure, } \\
5 / 8 \text { with } \\
\text { reim- } \\
\text { planta- } \\
\text { tion } \\
\text { proce- } \\
\text { dure } \\
\text { had } \\
\text { postop- } \\
\text { erative } \\
\text { SV } \\
\text { stenosis }\end{array}$ & $\begin{array}{l}\text { N=80 } \\
(<1 \\
\text { year=56), } \\
\text { MAPCA } \\
\text { ipsilat- } \\
\text { eral } \\
\text { lung } \\
\text { (56), } \\
\text { coil em- } \\
\text { boliza- } \\
\text { tion } \\
(31), \\
\text { surgical } \\
\text { ligation } \\
(12), \text { no } \\
\text { inter- } \\
\text { vention } \\
(13) \text { SV } \\
\text { surgery: } \\
13 / 28 \\
\text { with } \\
\text { baffle } \\
\text { proce- } \\
\text { dure, } \\
5 / 8 \text { with } \\
\text { reim- } \\
\text { planta- } \\
\text { tion } \\
\text { proce- } \\
\text { dure } \\
\text { had } \\
\text { postop- } \\
\text { erative } \\
\text { SV } \\
\text { stenosis }\end{array}$ & $\begin{array}{l}\text { N=80 } \\
(<1 \\
\text { year=56), } \\
\text { MAPCA } \\
\text { ipsilat- } \\
\text { eral } \\
\text { lung } \\
\text { (56), } \\
\text { coil em- } \\
\text { boliza- } \\
\text { tion } \\
(31), \\
\text { surgical } \\
\text { ligation } \\
\text { (12), no } \\
\text { inter- } \\
\text { vention } \\
(13), \text { SV } \\
\text { surgery: } \\
\text { 13/28 } \\
\text { with } \\
\text { baffle } \\
\text { proce- } \\
\text { dure, } \\
5 / 8 \text { with } \\
\text { reim- } \\
\text { planta- } \\
\text { tion } \\
\text { proce- } \\
\text { dure } \\
\text { had } \\
\text { postop- } \\
\text { erative } \\
\text { SV } \\
\text { stenosis }\end{array}$ & $\mathrm{E} 22$ \\
\hline
\end{tabular}




\begin{tabular}{|c|c|c|c|c|c|c|c|c|}
\hline Variables & Results & Results & Results & Results & Results & Results & Results & Refere \\
\hline $\begin{array}{l}\text { Eckhauser } \\
\text { et al, } \\
2013\end{array}$ & $\begin{array}{l}\mathrm{N}=5, \mathrm{SS} \\
\text { with } \\
\text { HLHS } \\
\text { between } \\
3 \text {-6 } \\
\text { years, } 4 \\
\text { patients } \\
\text { were } \\
\text { alive: } 2 \\
\text { after } \\
\text { cardiac } \\
\text { trans- } \\
\text { planta- } \\
\text { tion, } 1 \\
\text { under- } \\
\text { went a } \\
\text { Nor- } \\
\text { wood } \\
\text { opera- } \\
\text { tion, } 1 \\
\text { survived } \\
\text { at } \\
\text { staged } \\
\text { pallia- } \\
\text { tion } \\
\text { culmi- } \\
\text { nating } \\
\text { in a } \\
\text { Fontan } \\
\text { operation }\end{array}$ & $\begin{array}{l}\text { N=5, SS } \\
\text { with } \\
\text { HLHS } \\
\text { between } \\
3-6 \\
\text { years, } 4 \\
\text { patients } \\
\text { were } \\
\text { alive: } 2 \\
\text { after } \\
\text { cardiac } \\
\text { trans- } \\
\text { planta- } \\
\text { tion, } 1 \\
\text { under- } \\
\text { went a } \\
\text { Nor- } \\
\text { wood } \\
\text { opera- } \\
\text { tion, } 1 \\
\text { survived } \\
\text { at } \\
\text { staged } \\
\text { pallia- } \\
\text { tion } \\
\text { culmi- } \\
\text { nating } \\
\text { in a } \\
\text { Fontan } \\
\text { operation }\end{array}$ & $\begin{array}{l}\text { N=5, SS } \\
\text { with } \\
\text { HLHS } \\
\text { between } \\
3-6 \\
\text { years, } 4 \\
\text { patients } \\
\text { were } \\
\text { alive: } 2 \\
\text { after } \\
\text { cardiac } \\
\text { trans- } \\
\text { planta- } \\
\text { tion, } 1 \\
\text { under- } \\
\text { went a } \\
\text { Nor- } \\
\text { wood } \\
\text { opera- } \\
\text { tion, } 1 \\
\text { survived } \\
\text { at } \\
\text { staged } \\
\text { pallia- } \\
\text { tion } \\
\text { culmi- } \\
\text { nating } \\
\text { in a } \\
\text { Fontan } \\
\text { operation }\end{array}$ & $\begin{array}{l}\text { N=5, SS } \\
\text { with } \\
\text { HLHS } \\
\text { between } \\
3 \text {-6 } \\
\text { years, } 4 \\
\text { patients } \\
\text { were } \\
\text { alive: } 2 \\
\text { after } \\
\text { cardiac } \\
\text { trans- } \\
\text { planta- } \\
\text { tion, } 1 \\
\text { under- } \\
\text { went a } \\
\text { Nor- } \\
\text { wood } \\
\text { opera- } \\
\text { tion, } 1 \\
\text { survived } \\
\text { at } \\
\text { staged } \\
\text { pallia- } \\
\text { tion } \\
\text { culmi- } \\
\text { nating } \\
\text { in a } \\
\text { Fontan } \\
\text { operation }\end{array}$ & $\begin{array}{l}\mathrm{N}=5, \mathrm{SS} \\
\text { with } \\
\text { HLHS } \\
\text { between } \\
3 \text {-6 } \\
\text { years, } 4 \\
\text { patients } \\
\text { were } \\
\text { alive: } 2 \\
\text { after } \\
\text { cardiac } \\
\text { trans- } \\
\text { planta- } \\
\text { tion, } 1 \\
\text { under- } \\
\text { went a } \\
\text { Nor- } \\
\text { wood } \\
\text { opera- } \\
\text { tion, } 1 \\
\text { survived } \\
\text { at } \\
\text { staged } \\
\text { pallia- } \\
\text { tion } \\
\text { culmi- } \\
\text { nating } \\
\text { in a } \\
\text { Fontan } \\
\text { operation }\end{array}$ & $\begin{array}{l}\text { N=5, SS } \\
\text { with } \\
\text { HLHS } \\
\text { between } \\
3-6 \\
\text { years, } 4 \\
\text { patients } \\
\text { were } \\
\text { alive: } 2 \\
\text { after } \\
\text { cardiac } \\
\text { trans- } \\
\text { planta- } \\
\text { tion, } 1 \\
\text { under- } \\
\text { went a } \\
\text { Nor- } \\
\text { wood } \\
\text { opera- } \\
\text { tion, } 1 \\
\text { survived } \\
\text { at } \\
\text { staged } \\
\text { pallia- } \\
\text { tion } \\
\text { culmi- } \\
\text { nating } \\
\text { in a } \\
\text { Fontan } \\
\text { operation }\end{array}$ & $\begin{array}{l}\text { N=5, SS } \\
\text { with } \\
\text { HLHS } \\
\text { between } \\
3-6 \\
\text { years, } 4 \\
\text { patients } \\
\text { were } \\
\text { alive: } 2 \\
\text { after } \\
\text { cardiac } \\
\text { trans- } \\
\text { planta- } \\
\text { tion, } 1 \\
\text { under- } \\
\text { went a } \\
\text { Nor- } \\
\text { wood } \\
\text { opera- } \\
\text { tion, } 1 \\
\text { survived } \\
\text { at } \\
\text { staged } \\
\text { pallia- } \\
\text { tion } \\
\text { culmi- } \\
\text { nating } \\
\text { in a } \\
\text { Fontan } \\
\text { operation }\end{array}$ & E10 \\
\hline
\end{tabular}




\begin{tabular}{|c|c|c|c|c|c|c|c|c|}
\hline Variables & Results & Results & Results & Results & Results & Results & Results & Refere \\
\hline $\begin{array}{l}\text { Brink J } \\
\text { et al, } \\
2015\end{array}$ & $\begin{array}{l}20 \\
\text { surgical } \\
\text { patients } \\
\text { of SS } \\
\text { were } \\
\text { followed } \\
\text { for } \\
1.3-38.5 \\
\text { years } \\
\text { (mean } \\
13.7 \pm 10.3 \\
\text { years) } \\
\text { with 5 } \\
\text { patients } \\
\text { develo- } \\
\text { ping } \\
\text { postope- } \\
\text { rative } \\
\text { pulmo- } \\
\text { nary } \\
\text { vein } \\
\text { stenosis, } \\
3 \\
\text { (14.3\%) } \\
\text { patients } \\
\text { were } \\
\text { reoperated }\end{array}$ & $\begin{array}{l}20 \\
\text { surgical } \\
\text { patients } \\
\text { of SS } \\
\text { were } \\
\text { followed } \\
\text { for } \\
1.3-38.5 \\
\text { years } \\
\text { (mean } \\
13.7 \pm 10.3 \\
\text { years) } \\
\text { with 5 } \\
\text { patients } \\
\text { develo- } \\
\text { ping } \\
\text { postope- } \\
\text { rative } \\
\text { pulmo- } \\
\text { nary } \\
\text { vein } \\
\text { stenosis, } \\
3 \\
\text { (14.3\%) } \\
\text { patients } \\
\text { were } \\
\text { reoperated }\end{array}$ & $\begin{array}{l}20 \\
\text { surgical } \\
\text { patients } \\
\text { of SS } \\
\text { were } \\
\text { followed } \\
\text { for } \\
1.3-38.5 \\
\text { years } \\
\text { (mean } \\
13.7 \pm 10.3 \\
\text { years) } \\
\text { with 5 } \\
\text { patients } \\
\text { develo- } \\
\text { ping } \\
\text { postope- } \\
\text { rative } \\
\text { pulmo- } \\
\text { nary } \\
\text { vein } \\
\text { stenosis, } \\
3 \\
\text { (14.3\%) } \\
\text { patients } \\
\text { were } \\
\text { reoperated }\end{array}$ & $\begin{array}{l}20 \\
\text { surgical } \\
\text { patients } \\
\text { of SS } \\
\text { were } \\
\text { followed } \\
\text { for } \\
1.3-38.5 \\
\text { years } \\
\text { (mean } \\
\text { 13.7 } 10.3 \\
\text { years) } \\
\text { with 5 } \\
\text { patients } \\
\text { develo- } \\
\text { ping } \\
\text { postope- } \\
\text { rative } \\
\text { pulmo- } \\
\text { nary } \\
\text { vein } \\
\text { stenosis, } \\
3 \\
\text { (14.3\%) } \\
\text { patients } \\
\text { were } \\
\text { reoperated }\end{array}$ & $\begin{array}{l}20 \\
\text { surgical } \\
\text { patients } \\
\text { of SS } \\
\text { were } \\
\text { followed } \\
\text { for } \\
1.3-38.5 \\
\text { years } \\
\text { (mean } \\
\text { 13.7 } \pm 10.3 \\
\text { years) } \\
\text { with 5 } \\
\text { patients } \\
\text { develo- } \\
\text { ping } \\
\text { postope- } \\
\text { rative } \\
\text { pulmo- } \\
\text { nary } \\
\text { vein } \\
\text { stenosis, } \\
3 \\
\text { (14.3\%) } \\
\text { patients } \\
\text { were } \\
\text { reoperated }\end{array}$ & $\begin{array}{l}20 \\
\text { surgical } \\
\text { patients } \\
\text { of SS } \\
\text { were } \\
\text { followed } \\
\text { for } \\
1.3-38.5 \\
\text { years } \\
\text { (mean } \\
13.7 \pm 10.3 \\
\text { years) } \\
\text { with } 5 \\
\text { patients } \\
\text { develo- } \\
\text { ping } \\
\text { postope- } \\
\text { rative } \\
\text { pulmo- } \\
\text { nary } \\
\text { vein } \\
\text { stenosis, } \\
3 \\
\text { (14.3\%) } \\
\text { patients } \\
\text { were } \\
\text { reoperated }\end{array}$ & $\begin{array}{l}20 \\
\text { surgical } \\
\text { patients } \\
\text { of SS } \\
\text { were } \\
\text { followed } \\
\text { for } \\
1.3-38.5 \\
\text { years } \\
\text { (mean } \\
13.7 \pm 10.3 \\
\text { years) } \\
\text { with 5 } \\
\text { patients } \\
\text { develo- } \\
\text { ping } \\
\text { postope- } \\
\text { rative } \\
\text { pulmo- } \\
\text { nary } \\
\text { vein } \\
\text { stenosis, } \\
3 \\
\text { (14.3\%) } \\
\text { patients } \\
\text { were } \\
\text { reoperated }\end{array}$ & E6 \\
\hline
\end{tabular}




\begin{tabular}{|c|c|c|c|c|c|c|c|c|}
\hline Variables & Results & Results & Results & Results & Results & Results & Results & Refere \\
\hline $\begin{array}{l}\text { Wang H } \\
\text { et al, } \\
2018\end{array}$ & $\begin{array}{l}\text { Out of } \\
47 \\
\text { patients, } \\
28 \text { non- } \\
\text { operative } \\
\text { medical } \\
\text { manage- } \\
\text { ment, } \\
18 \\
(38.3 \%) \\
\text { patients } \\
\text { under- } \\
\text { went } \\
\text { surgery: } \\
\text { Intra- } \\
\text { atrial } \\
\text { baffle } \\
(12), \\
\text { reim- } \\
\text { planta- } \\
\text { tion (5), } \\
\text { pneu- } \\
\text { monec- } \\
\text { tomy } \\
(1), \\
\text { median } \\
\text { follow- } \\
\text { up } 3.55 \\
\text { years, } \\
\text { overall } \\
\text { mortal- } \\
\text { ity } \\
\text { baf- }\end{array}$ & $\begin{array}{l}\text { Out of } \\
47 \\
\text { patients, } \\
28 \text { non- } \\
\text { operative } \\
\text { medical } \\
\text { manage- } \\
\text { ment, } \\
18 \\
(38.3 \%) \\
\text { patients } \\
\text { under- } \\
\text { went } \\
\text { surgery: } \\
\text { Intra- } \\
\text { atrial } \\
\text { baffle } \\
(12), \\
\text { reim- } \\
\text { planta- } \\
\text { tion (5), } \\
\text { pneu- } \\
\text { monec- } \\
\text { tomy } \\
(1), \\
\text { median } \\
\text { follow- } \\
\text { up } 3.55 \\
\text { years, } \\
\text { overall } \\
\text { mortal- } \\
\text { ity } \\
\text { baf- }\end{array}$ & $\begin{array}{l}\text { Out of } \\
47 \\
\text { patients, } \\
28 \text { non- } \\
\text { operative } \\
\text { medical } \\
\text { manage- } \\
\text { ment, } \\
18 \\
(38.3 \%) \\
\text { patients } \\
\text { under- } \\
\text { went } \\
\text { surgery: } \\
\text { Intra- } \\
\text { atrial } \\
\text { baffle } \\
(12), \\
\text { reim- } \\
\text { planta- } \\
\text { tion (5), } \\
\text { pneu- } \\
\text { monec- } \\
\text { tomy } \\
(1), \\
\text { median } \\
\text { follow- } \\
\text { up } 3.55 \\
\text { years, } \\
\text { overall } \\
\text { mortal- } \\
\text { ity } \\
\text { baf- }\end{array}$ & $\begin{array}{l}\text { Out of } \\
47 \\
\text { patients, } \\
28 \text { non- } \\
\text { operative } \\
\text { medical } \\
\text { manage- } \\
\text { ment, } \\
18 \\
\text { (38.3\%) } \\
\text { patients } \\
\text { under- } \\
\text { went } \\
\text { surgery: } \\
\text { Intra- } \\
\text { atrial } \\
\text { baffle } \\
\text { (12), } \\
\text { reim- } \\
\text { planta- } \\
\text { tion (5), } \\
\text { pneu- } \\
\text { monec- } \\
\text { tomy } \\
\text { (1), } \\
\text { median } \\
\text { follow- } \\
\text { up } 3.55 \\
\text { years, } \\
\text { overall } \\
\text { mortal- } \\
\text { ity } \\
\text { baf- }\end{array}$ & $\begin{array}{l}\text { Out of } \\
47 \\
\text { patients, } \\
28 \text { non- } \\
\text { operative } \\
\text { medical } \\
\text { manage- } \\
\text { ment, } \\
18 \\
(38.3 \%) \\
\text { patients } \\
\text { under- } \\
\text { went } \\
\text { surgery: } \\
\text { Intra- } \\
\text { atrial } \\
\text { baffle } \\
(12), \\
\text { reim- } \\
\text { planta- } \\
\text { tion (5), } \\
\text { pneu- } \\
\text { monec- } \\
\text { tomy } \\
(1), \\
\text { median } \\
\text { follow- } \\
\text { up } 3.55 \\
\text { years, } \\
\text { overall } \\
\text { mortal- } \\
\text { ity } \\
\text { baf- }\end{array}$ & $\begin{array}{l}\text { Out of } \\
47 \\
\text { patients, } \\
28 \text { non- } \\
\text { operative } \\
\text { medical } \\
\text { manage- } \\
\text { ment, } \\
18 \\
(38.3 \%) \\
\text { patients } \\
\text { under- } \\
\text { went } \\
\text { surgery: } \\
\text { Intra- } \\
\text { atrial } \\
\text { baffle } \\
(12), \\
\text { reim- } \\
\text { planta- } \\
\text { tion (5), } \\
\text { pneu- } \\
\text { monec- } \\
\text { tomy } \\
(1), \\
\text { median } \\
\text { follow- } \\
\text { up } 3.55 \\
\text { years, } \\
\text { overall } \\
\text { mortal- } \\
\text { ity } \\
\text { baf- }\end{array}$ & $\begin{array}{l}\text { Out of } \\
47 \\
\text { patients, } \\
28 \text { non- } \\
\text { operative } \\
\text { medical } \\
\text { manage- } \\
\text { ment, } \\
18 \\
(38.3 \%) \\
\text { patients } \\
\text { under- } \\
\text { went } \\
\text { surgery: } \\
\text { Intra- } \\
\text { atrial } \\
\text { baffle } \\
(12), \\
\text { reim- } \\
\text { planta- } \\
\text { tion (5), } \\
\text { pneu- } \\
\text { monec- } \\
\text { tomy } \\
(1), \\
\text { median } \\
\text { follow- } \\
\text { up } 3.55 \\
\text { years, } \\
\text { overall } \\
\text { mortal- } \\
\text { ity } \\
\text { baf- }\end{array}$ & 13 \\
\hline & $\begin{array}{l}\text { fle/reimpl } \\
37.5 \%, \\
\text { medical } \\
\text { manage- } \\
\text { ment } \\
(46.7 \%) \text {, } \\
\text { Median } \\
\text { follow- } \\
\text { up } 2.74 \\
\text { years } \\
\text { (IQR: } \\
0.46- \\
9.68), \\
11 / 16 \\
(68.8 \%) \\
\text { had } \\
\text { post } \\
\text { repair } \\
\text { stenosis } \\
\text { of SV. }\end{array}$ & $\begin{array}{l}\text { tfiohtreimpl } \\
37.5 \%, \\
\text { medical } \\
\text { manage- } \\
\text { ment } \\
(46.7 \%) \text {, } \\
\text { Median } \\
\text { follow- } \\
\text { up } 2.74 \\
\text { years } \\
\text { (IQR: } \\
0.46- \\
9.68), \\
11 / 16 \\
(68.8 \%) \\
\text { had } \\
\text { post } \\
\text { repair } \\
\text { stenosis } \\
\text { of SV. }\end{array}$ & $\begin{array}{l}37.5 \%, \\
\text { medical } \\
\text { manage- } \\
\text { ment } \\
(46.7 \%), \\
\text { Median } \\
\text { follow- } \\
\text { up } 2.74 \\
\text { years } \\
\text { (IQR: } \\
0.46- \\
9.68), \\
11 / 16 \\
(68.8 \%) \\
\text { had } \\
\text { post } \\
\text { repair } \\
\text { stenosis } \\
\text { of SV. } 64\end{array}$ & $\begin{array}{l}37.5 \%, \\
\text { medical } \\
\text { manage- } \\
\text { ment } \\
(46.7 \%), \\
\text { Median } \\
\text { follow- } \\
\text { up } 2.74 \\
\text { years } \\
\text { (IQR: } \\
0.46- \\
9.68), \\
11 / 16 \\
\text { (68.8\%) } \\
\text { had } \\
\text { post } \\
\text { repair } \\
\text { stenosis } \\
\text { of SV. }\end{array}$ & $\begin{array}{l}37.5 \%, \\
\text { medical } \\
\text { manage- } \\
\text { ment } \\
(46.7 \%) \text {, } \\
\text { Median } \\
\text { follow- } \\
\text { up } 2.74 \\
\text { years } \\
\text { (IQR: } \\
0.46- \\
9.68), \\
11 / 16 \\
(68.8 \%) \\
\text { had } \\
\text { post } \\
\text { repair } \\
\text { stenosis } \\
\text { of SV. }\end{array}$ & $\begin{array}{l}\text { tilophreimpl } \\
37.5 \%, \\
\text { medical } \\
\text { manage- } \\
\text { ment } \\
(46.7 \%) \text {, } \\
\text { Median } \\
\text { follow- } \\
\text { up } 2.74 \\
\text { years } \\
\text { (IQR: } \\
0.46- \\
9.68), \\
11 / 16 \\
\text { (68.8\%) } \\
\text { had } \\
\text { post } \\
\text { repair } \\
\text { stenosis } \\
\text { of SV. }\end{array}$ & $\begin{array}{l}\text { tfiophreimpl } \\
37.5 \%, \\
\text { medical } \\
\text { manage- } \\
\text { ment } \\
(46.7 \%) \text {, } \\
\text { Median } \\
\text { follow- } \\
\text { up } 2.74 \\
\text { years } \\
\text { (IQR: } \\
0.46- \\
9.68), \\
11 / 16 \\
(68.8 \%) \\
\text { had } \\
\text { post } \\
\text { repair } \\
\text { stenosis } \\
\text { of SV. }\end{array}$ & \\
\hline
\end{tabular}




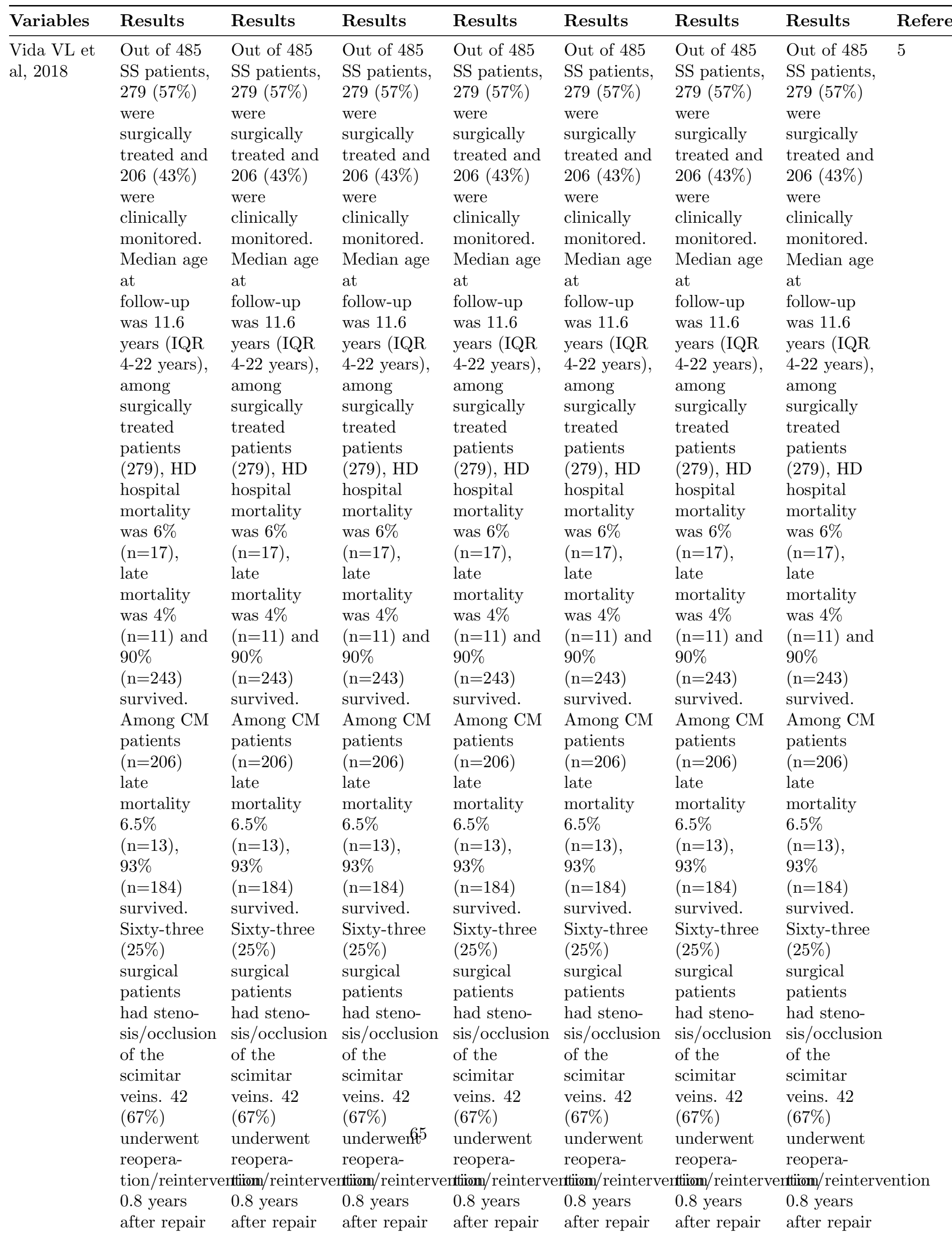




\begin{tabular}{|c|c|c|c|c|c|c|c|c|}
\hline Variables & Results & Results & Results & Results & Results & Results & Results & Refere \\
\hline & $\begin{array}{l}\text { No. of } \\
\text { pa- } \\
\text { tients }\end{array}$ & $\begin{array}{l}\text { Overall } \\
\text { mortal- } \\
\text { ity }\end{array}$ & $\begin{array}{l}\text { Medical } \\
\text { treat- } \\
\text { ment }\end{array}$ & $\begin{array}{l}\text { MAPCA } \\
\text { occlu- } \\
\text { sion }\end{array}$ & $\mathrm{PDA} / \mathrm{COA}$ & $\begin{array}{l}\text { Complete } \\
\text { repair }\end{array}$ & $\begin{array}{l}\text { Pulmonary } \\
\text { resec- } \\
\text { tion }\end{array}$ & \\
\hline $\begin{array}{l}\text { Huddleston } \\
\text { CBC et } \\
\text { al, } 1999\end{array}$ & 12 & 4 & $2(2)$ & $1(1)$ & - & $7(1)$ & $5(0)$ & E2 \\
\hline $\begin{array}{l}\text { Najm } \\
\text { HK et } \\
\text { al, } 1996\end{array}$ & 32 & 5 & 7 & $5(3)$ & $2(2)$ & $17(0)$ & $1(0)$ & 19 \\
\hline $\begin{array}{l}\text { Dupuis } \\
\text { C et al, } \\
1993\end{array}$ & 25 & 16 & $10(7)$ & $6(1)$ & $5(5)$ & 0 & $3(2)$ & 11 \\
\hline $\begin{array}{l}\text { Torres } \\
\text { AR et } \\
\text { al, } 1993\end{array}$ & 14 & 1 & 0 & $3(1)$ & 0 & $10(0)$ & $1(0)$ & E5 \\
\hline $\begin{array}{l}\text { Brown } \\
\text { JW et } \\
\text { al, } 2003\end{array}$ & 10 & 0 & 0 & $3(0)$ & 0 & $10(0)$ & 0 & E7 \\
\hline
\end{tabular}

[Abbreviations: CM: Clinically monitored; COA: Coarctation of aorta; CHD: Chronic heart disease; HD: Hospital death; HLHS: Hypoplastic left heart syndrome; IQR: Interquartile range; IVCLA: Left atrium; MAPCAs: Major aortopulmonary collateral arteries; PDA: Persistent arterial duct; SS: scimitar syndrome; SV: scimitar vein]
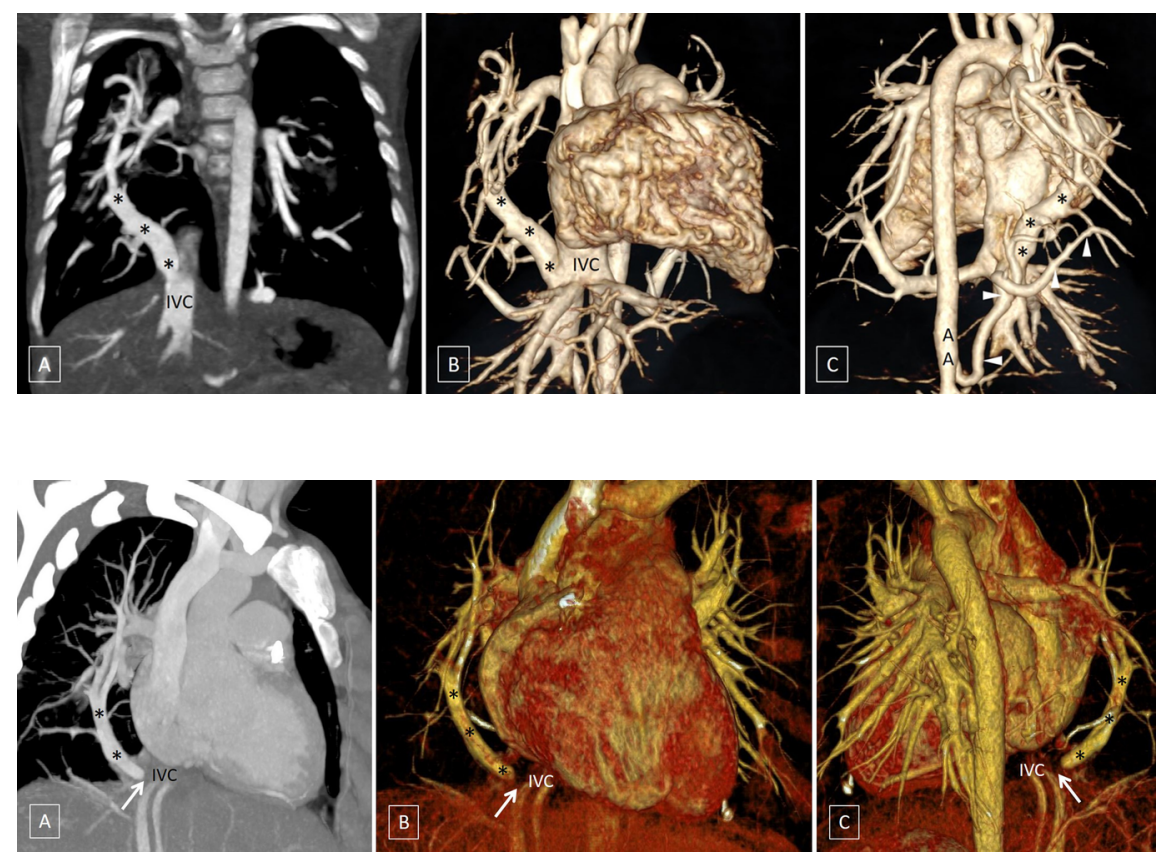

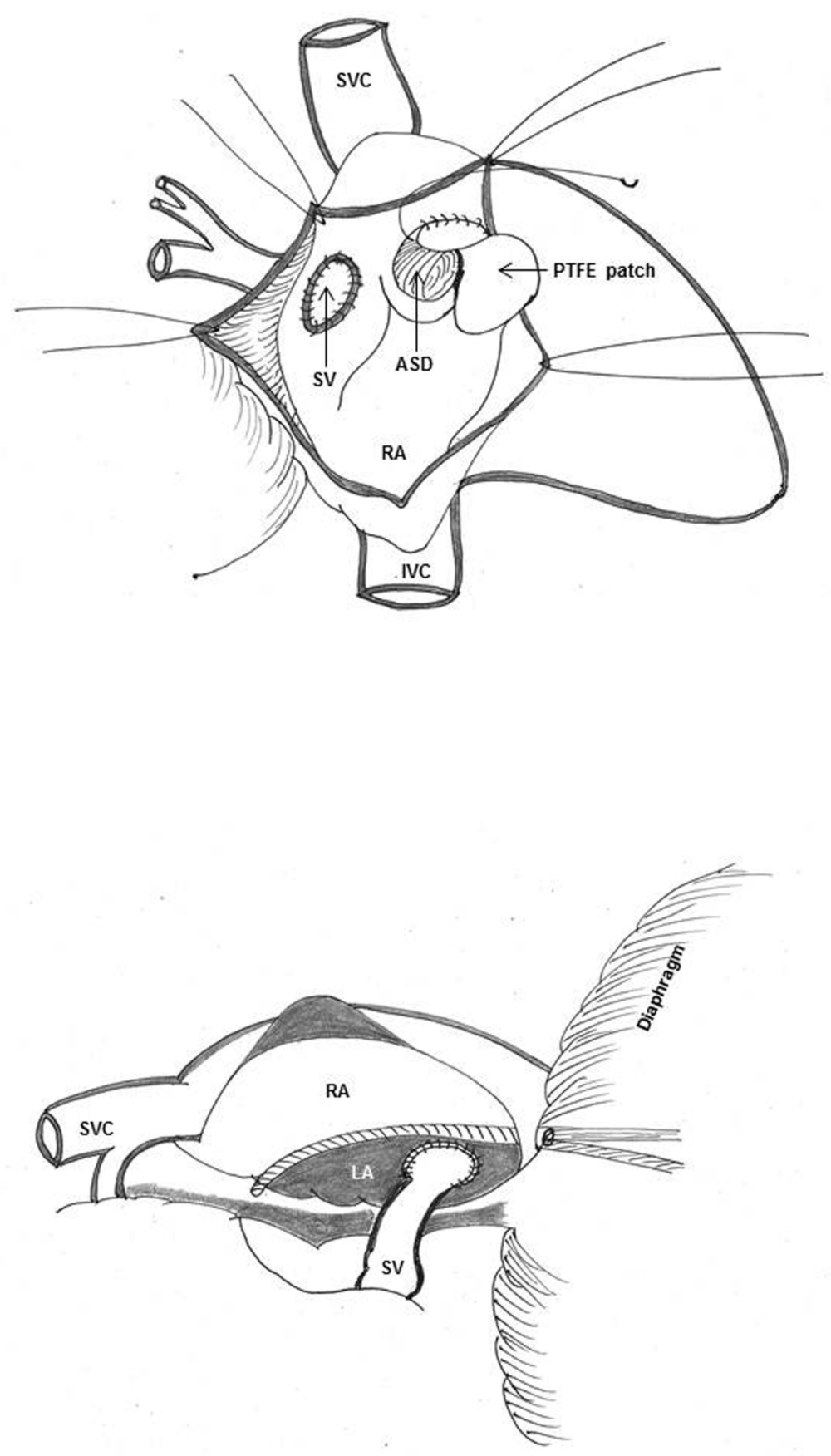

67 

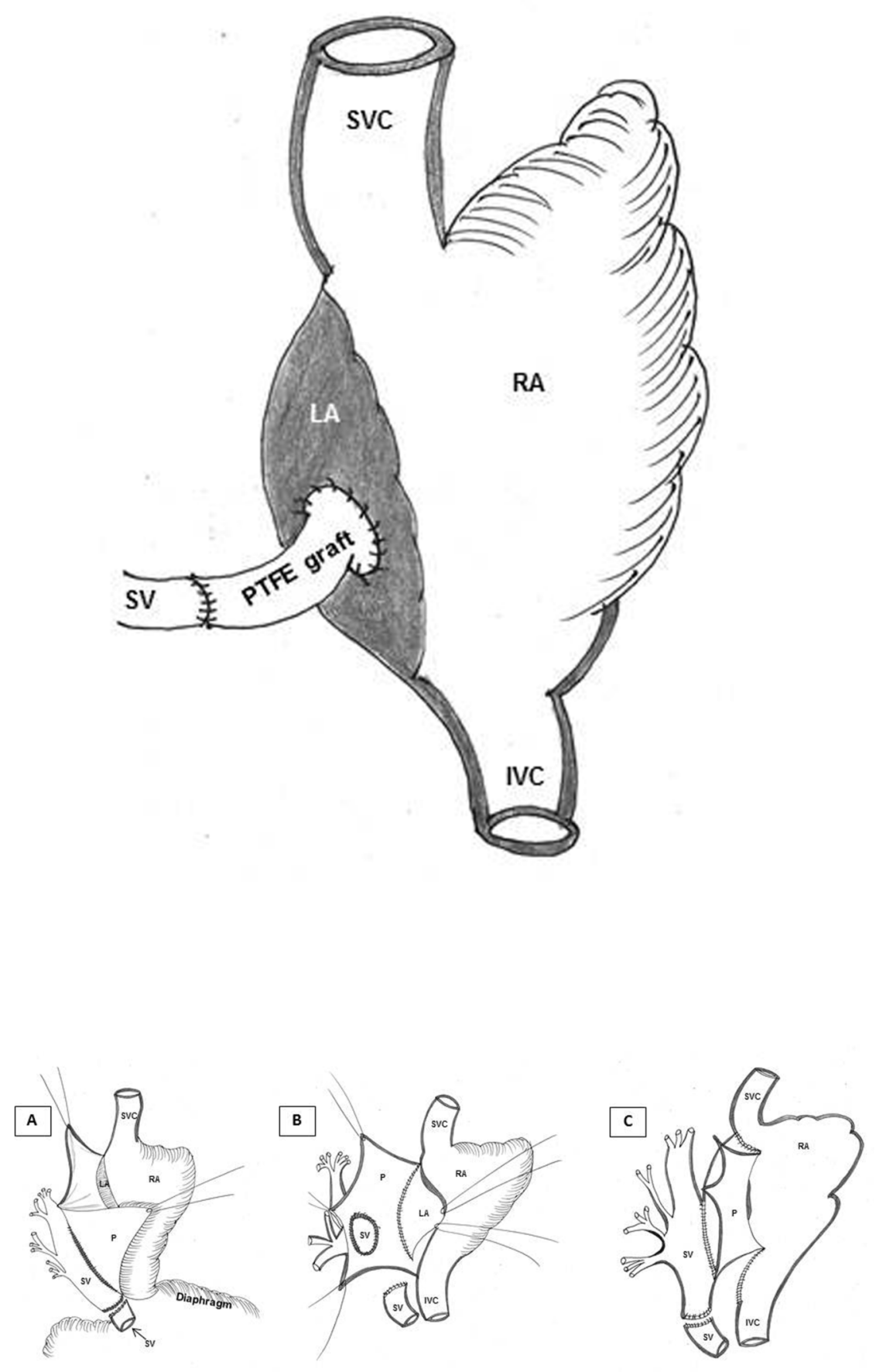

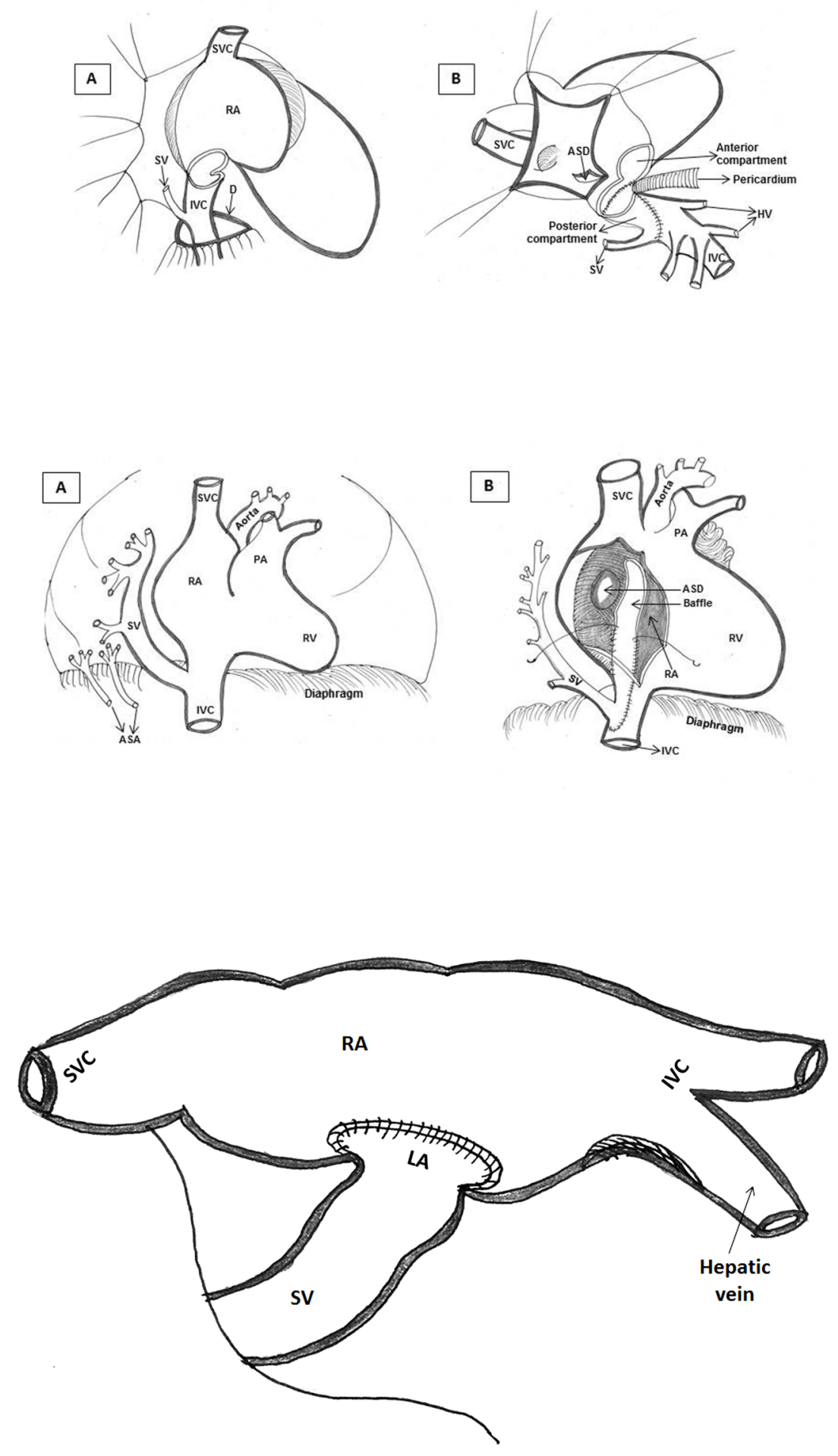


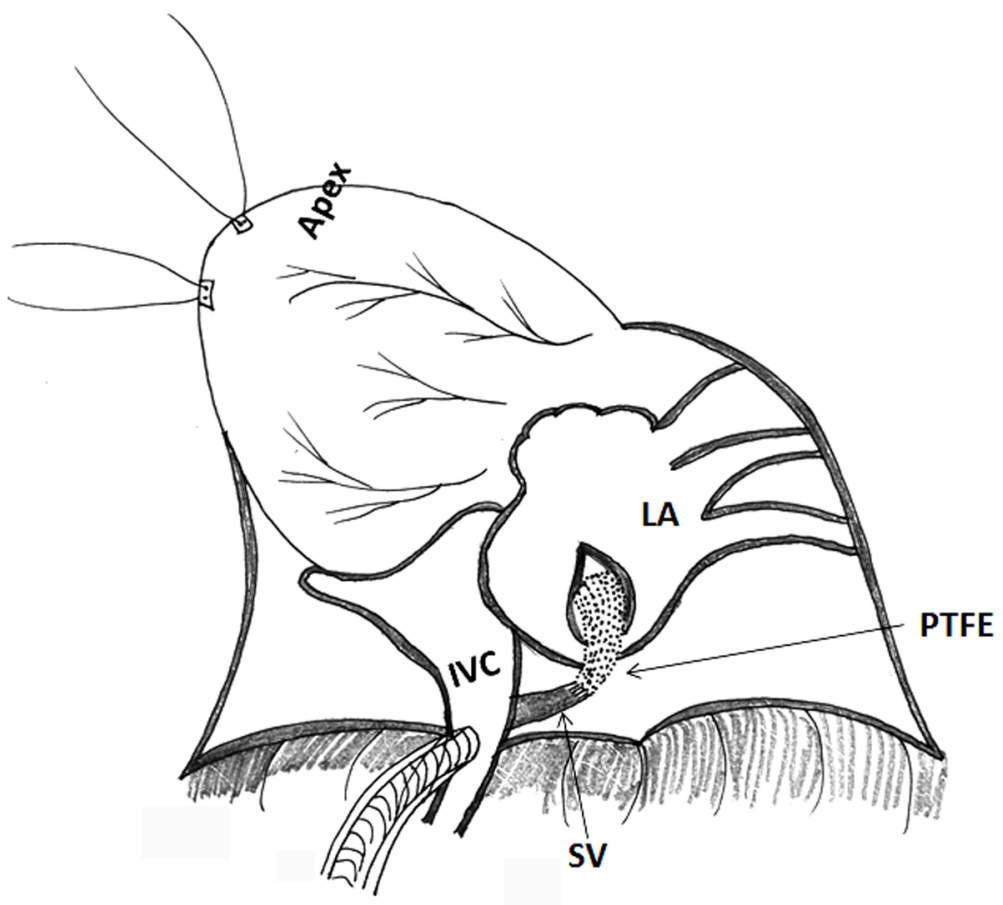

